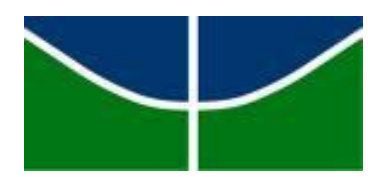

Universidade de Brasília - UnB Instituto de Ciências Humanas - IH

Departamento de Serviço Social - SER

Trabalho de Conclusão de Curso - TCC

\title{
OS DESAFIOS DA AVALIAÇÃO SOCIAL PARA ACESSO AO BPC
}

Alan Teles da Silva

Brasília - DF, agosto de 2010 
Alan Teles da Silva

OS DESAFIOS DA AVALIAÇÃO SOCIAL PARA ACESSO AO BPC

Trabalho de Conclusão de Curso apresentado ao Departamento de Serviço Social do Instituto de Ciências Humanas da Universidade de Brasília como requisito parcial para obtenção do título de Bacharel em Serviço Social.

Orientadora: Prof ${ }^{\mathrm{a}}$. Dr ${ }^{\mathrm{a}}$. Ivanete Salete Boschetti.

Brasília - DF, agosto de 2010 
Dedico esse trabalho ao meu grande e único amor ontem, hoje e amanhã, Danuta. 


\section{AGRADECIMENTOS}

Como em tudo o que fazemos em nossas vidas, escolhemos um caminho que nos leva a conquistas, alegrias, limites e dificuldades, caminho impossível se concretizar sem a colaboração de outros sujeitos. Todo esse processo de escolha profissional, construção teórico-metodológica e amadurecimento pessoal só foi possível diante da contribuição de pessoas importantes e especiais que, cada uma ao seu modo e dentro das suas possibilidades, permitiu a concretização deste sonho. Por isso, realizar alguns agradecimentos nesse momento é uma necessidade imperiosa.

Inicialmente, agradeço a Deus, sobretudo, pela insistência em ser tão fiel na minha vida, apesar de, em muitos momentos, eu não ser fiel a Ele. Com tantas angústias e alegrias no decorrer desses semestres, era bom saber que "há tempo para todo o propósito debaixo do céu". O tempo chegou e um ciclo se fecha aqui.

À Danuta Dantas de Oliveira Martins, minha querida esposa e amiga, que literalmente me apresentou o que é o Serviço Social e, como se fosse pouco me despertar para tantas coisas da vida, em momento de grande dúvida sobre qual curso fazer, foi a responsável pela minha escolha pelo nosso curso que tanta felicidade me traz. Obrigado por me incentivar em todo o curso, acreditando na minha capacidade e apostando no meu sucesso. Por todo o amor, carinho, compreensão e dedicação que tem me proporcionado diariamente, obrigado. É bom ter a certeza de que casar com você foi a maior e melhor decisão da minha vida. Como sempre irá terminar, amo você.

À minha mãe, Laudelina Teles da Silva, que sempre me incentivou a estudar, não me pressionando pelas minhas incertezas profissionais com entradas e saídas de cursos; por ter sido sempre tão presente na minha vida e nas minhas escolhas; por todo o carinho e atenção que a fazem ser a melhor mãe do mundo.

À minha irmã, Angélica Teles da Silva, pelo carinho, atenção, confiança e amizade presencial e virtual. Também agradeço à pequena e amada Lívia Teles da Silva Alves, minha sobrinha que, embora eu tenha pouquíssima convivência presencial em seus cinco anos de vida, ela é muito importante na minha vida.

À Prof ${ }^{a}$. Dr ${ }^{a}$. Ivanete Salete Boschetti, pela oportunidade de participação no Grupo de Estudos e Pesquisas sobre a Seguridade Social e Trabalho (GESST) e por ter aceitado o convite para ser a minha orientadora. A discussão sobre o Serviço Social, a Política Social e a Profa. Ivanete se confunde, parece uma coisa só. Ela sabe tudo. Outro sonho é ter o conhecimento dela um dia.

À Prof ${ }^{a}$. Dr ${ }^{a}$. Rosa Helena Stein, exemplo de profissional e pessoa no Departamento de Serviço Social da UnB. Ainda me lembro das preciosas aulas de Introdução ao Serviço 
Social que muito contribuíram para minha certeza em ser assistente social. Obrigado por aceitar o convite para participar dessa banca.

Por ter aceitado em participar dessa banca, os meus agradecimentos à Maria Lucia Lopes da Silva.

A todos os integrantes do GESST, Getúlio Ferreira, Júlia de Albuquerque Pacheco e Jorge Augusto Bezerra, pelas discussões das pesquisas nesses dois anos.

Às assistentes sociais do INSS que aceitaram em contribuir com minha pesquisa por meio da concessão de entrevistas com informações muito importantes, essenciais.

Às professoras e aos professores tanto do Departamento de Serviço Social quanto de outros Departamentos da UnB que contribuíram para a minha formação profissional e para o desenvolvimento de uma análise crítica da realidade social.

À Lívia Barbosa, agora Prof ${ }^{a}$. Lívia, por ter aceitado ser minha supervisora de campo na Anis - Instituto de Bioética, Direitos Humanos e Gênero, pelas discussões e por ter contribuído pela descoberta do meu objeto de estudo na temática do BPC.

A todos os colegas da turma 2007/1 do Curso de Graduação em Serviço Social da UnB, turma da qual faço parte, um grupo que é muito perceptível o nível de amadurecimento profissional e pessoal. Obrigado pelas discussões, debates, trocas de idéias e amizades que muito contribuíram para a minha vida em Brasília longe dos meus familiares.

A todos que, de alguma maneira, contribuíram com esse processo de amadurecimento e fechamento de uma etapa importante da minha história profissional e pessoal, meus sinceros agradecimentos. 


\section{RESUMO}

Este Trabalho de Conclusão de Curso (TCC) teve como objetivo compreender em que medida o processo de avaliação social para o acesso ao Benefício de Prestação Continuada da Assistência Social (BPC), realizado pelas assistentes sociais do Instituto Nacional do Seguro Social (INSS), pode contribuir para ampliar o acesso ao benefício e superar as concepções restritas de deficiência e de incapacidade para o trabalho e para a vida independente. Conhecer os desafios da avaliação social para acesso ao BPC é fundamental para criar estratégias de superação de dificuldades no processo de avaliação social para expandir o alcance da política social para as pessoas com deficiência. A pesquisa fez uso da metodologia qualitativa de levantamento e análise de dados nas agências do INSS do Distrito Federal onde havia assistente social que possuía a atribuição de realizar a avaliação social nas pessoas com deficiência. Esta pesquisa apresentou as seguintes etapas metodológicas: 1. levantamento bibliográfico da literatura sobre o BPC, Assistência Social, Deficiência e Avaliação Social; 2. análise documental das categorias em análise; 3. trabalho de campo: a) construção de um instrumento de coleta de dados para realizar as entrevistas semi-estruturadas; b) realização de cinco entrevistas com as assistentes sociais responsáveis pela avaliação social com gravação de voz das entrevistadas; 3 . transcrição das entrevistas e análise qualitativa dos dados. Os resultados da pesquisa apontam que: 1. houve uma expansão do acesso ao BPC no Distrito Federal, principalmente, para pessoas com deficiência moderada muito por conta da nova concepção do conceito de deficiência para além dos critérios médicos, levando em consideração os domínios incorporados dos componentes fatores ambientais e atividade e participação no processo de avaliação social; 2. os principais desafios da avaliação estão concentrados nas fragilidades do trabalho das assistentes sociais que realizam a avaliação social em relação: a) às competências e atribuições profissionais; b) aos aspectos materiais, éticos e técnicos no exercício profissional; c) ao novo instrumento de avaliação social, existe uma dificuldade em avaliar alguns elementos do componente atividade e participação em crianças. Os resultados mostram que já existe a incorporação dos novos elementos necessários para se avaliar quem é a pessoa com deficiência elegível ao BPC de acordo com a Classificação Internacional de Funcionalidades, Incapacidade e Saúde (CIF) e que a avaliação social é um instrumento importante para a expansão do BPC para as pessoas com deficiência.

Palavras-chave: BPC, Deficiência, Avaliação Social, INSS. 


\section{SUMÁRIO}

$\begin{array}{ll}\text { Introdução } & 8\end{array}$

$\begin{array}{ll}\text { Justificativa } & 13\end{array}$

$\begin{array}{ll}\text { Metodologia } & 16\end{array}$

Método e Técnica da Pesquisa 16

$\begin{array}{ll}\text { Universo da Pesquisa } & 19\end{array}$

Análise dos Dados $\quad 20$

Capítulo 1 - O Debate acerca do Fenômeno da Deficiência 21

1.1 Introdução 21

1.2 Termos, Definições e Conceitos sobre a Deficiência 21

1.3 A Pessoa com Deficiência no Curso da História 25

1.4 O Modelo Médico de Deficiência 28

1.5 O Modelo Social de Deficiência 31

1.6 O Fenômeno da Deficiência no Brasil 36

Capítulo 2 - A Trajetória do BPC no Brasil 42

2.1 O Benefício de Prestação Continuada 42

2.2 A Operacionalização do BPC 49

2.3 BPC e Pessoa com Deficiência 53

2.4 BPC, Deficiência e Avaliação Social 56

Capítulo 3 - Serviço Social e os Desafios da Avaliação Social 64

3.1 O Serviço Social Previdenciário $\quad 64$

3.2 O Serviço Social, a Avaliação Social e o Desafio do Concurso Público 74

3.3 Competências e Atribuições Profissionais do Assistente Social no INSS 77

3.4 Aspectos Materiais, Técnicos e Éticos no Exercício Profissional 82

3.5 A Deficiência, os Critérios de Elegibilidade e a Avaliação Social 85

$\begin{array}{ll}\text { Considerações Finais } & 90\end{array}$

Referências Bibliográficas $\quad 94$

$\begin{array}{ll}\text { Anexo } & 102\end{array}$ 


\section{INTRODUÇÃO}

A seguridade social compreende um conjunto integrado de ações de iniciativa dos poderes públicos e da sociedade destinado a assegurar os direitos relativos à saúde, à previdência social e à assistência social (BRASIL, 1988). Parte do trinômio da seguridade social no Brasil, a assistência social é considerada um direito social, será prestada a quem dela necessitar, independentemente de contribuição à seguridade social (BRASIL, 1988; 1993; BOSCHETTI, 2002). A assistência social, direito do cidadão e dever do Estado, é política de seguridade social não contributiva, que deve prover os mínimos sociais, realizada por meio de um conjunto integrado de ações de iniciativa pública e da sociedade, para garantir o atendimento às necessidades básicas (BRASIL, 1993). É a partir desse marco regulatório que todas as legislações que fundamentam as principais políticas de assistência social do Brasil vão se basear (BOSCHETTI, 2002; 2006).

A instituição do BPC no Brasil foi realizada pela Constituição Federal de 1988 (CF/1988), artigo 203, inciso V, regulamentada em 1993 pela Lei Orgânica da Assistência Social - LOAS (Lei $n^{0}$. 8.742, de 07 de dezembro de 1993), complementada e retificada pelo Decreto Federal $n^{0}$. 1.744, de 08 de dezembro de 1995, pela Medida Provisória $n^{0}$. 1.426/1996, posteriormente Lei $n^{0}$. 9.720, de 30 de novembro de 1998 (BRASIL, 2007d). Hoje, o BPC está regulamentado pelos Decretos $n^{0}$. 6.214, de 26 de setembro de 2007, e $\mathrm{n}^{0}$. 6.564, de 12 de setembro de 2008. O BPC substituiu a Renda Mensal Vitalícia (RMV) que, no âmbito da previdência social, concedeu entre 1975 e 1996 uma renda a pessoas idosas e com deficiência que comprovassem sua incapacidade para o trabalho. É um benefício operacionalizado pelo INSS e financiado com recursos do Fundo Nacional de Assistência Social - FNAS (BOSCHETTI, 2006).

O BPC é um benefício da assistência social que consiste na transferência mensal e temporária de renda, sem contrapartidas, equivalente a um salário mínimo destinado às pessoas com deficiência ${ }^{1}$ e também às idosas com 65 anos de idade ou mais, ambas com renda per capita familiar inferior a 1/44 de salário mínimo (BRASIL, 1993; 2007a). Em maio de 2010, segundo o Boletim Estatístico da Previdência Social, o benefício foi destinado para o atendimento a 3.261 .624 beneficiários em todo o Brasil, sendo que, desse total, 1.688 .881 $(51,78 \%)$ são pessoas com deficiência e 1.572 .743 (48,22\%) são idosos com 65 anos ou mais. Em relação ao investimento de recursos públicos no BPC, obtivemos um grande salto: de um montante de $\mathrm{R} \$ 172,342 \mathrm{mi}$, utilizados para o atendimento de pessoas com

$1 \quad$ Existe um debate sobre como devem ser apresentadas as nomenclaturas sobre as pessoas que vivem a experiência da deficiência. Neste TCC, será utilizada a expressão pessoa com deficiência para representar todo o conjunto das pessoas que sofrem opressão pelo corpo, pois é a designação utilizada pelo Conselho Nacional dos Direitos das Pessoas com Deficiência. 
deficiência e idosos no primeiro ano de implantação do benefício, em 1996, foi necessária a quantia superior a 16 bilhões de reais para o pagamento dos beneficiários no ano de 2009 e já foram aplicados $R \$ 8,2$ bi somente entre os meses de janeiro e maio de 2010 para a sua efetivação.

Para requerer o BPC, a pessoa idosa ou com deficiência deve procurar um dos postos do Instituto Nacional do Seguro Social (INSS), preencher o formulário de solicitação do benefício e de declaração de renda dos membros da família, comprovar residência e apresentar documentos próprios e da família para demonstrar as condições de renda (BRASIL, 2007b). Após a habilitação inicial, a pessoa com deficiência será encaminhada para uma avaliação social a ser realizada por assistente social do INSS e, em seguida, para uma avaliação médica em que terá a deficiência e o grau de incapacidade avaliados (MEDEIROS et. al, 2006; BRASIL, 2007b).

Vários são os pontos polêmicos da LOAS/1993, como o artigo 20, parágrafo 6ํ․, ao afirmar que a concessão do benefício ficará sujeita a exame médico pericial e laudo realizados pelos serviços de perícia médica do INSS. As maiores controvérsias sobre os critérios de elegibilidade do BPC dizem respeito à avaliação do que seja incapacidade para a vida independente das pessoas com deficiência requerentes do benefício assistencial (MEDEIROS et. al, 2006; SQUINCA, 2007; BRASIL, 2007c). Pesquisas revelam que os médicos-perito responsáveis pela avaliação pericial das pessoas com deficiência possuem critérios diversificados para avaliar a elegibilidade delas ao benefício (DINIZ et. al, 2007; MEDEIROS et. al, 2006). Essa constatação dos pesquisadores aponta para ausência de critérios objetivos na legislação, o que relega a responsabilidade de definir tais critérios somente às práticas individualizadas dos médicos-perito.

Uma ação civil pública movida pelo Ministério Público Federal e pela Defensoria Pública da União contra o INSS teve como objetivo requerer que as agências do INSS de todo o país deixem de exigir para a concessão do BPC que a pessoa com deficiência seja incapaz para os atos da vida civil (BRASIL, 2007c). A ação civil pública parte do pressuposto de que tal exigência para a concessão do BPC não diz respeito ao grau de dificuldade das pessoas para desempenharem os atos da vida diária, mas que a incapacidade para a vida independente das pessoas com deficiência deve ser avaliada apenas em termos de comprometimento da capacidade de exercer uma atividade laboral (BRASIL, 2007c). A ação postula que a exigência de incapacidade para a vida independente, conforme exigido pelas agências do INSS, é restritiva e excludente, retirando do alcance do benefício pessoas com deficiência que nos termos da CF/1988 teriam direito de recebê-lo.

Uma pesquisa realizada com médicos-perito do INSS de todo o país mostrou que $47 \%$ deles consideravam ineficiente ou menos que eficiente o único instrumento 
padronizado do INSS utilizado para avaliar a incapacidade para o trabalho e para a vida independente dos solicitantes do BPC, e somente $5 \%$ acreditam que o questionário é muito eficiente para o processo de seleção (DINIZ et. al, 2007; MEDEIROS et. al, 2006). Segundo os autores do estudo, esses resultados sobre a avaliação que os médicos-perito têm do único instrumento padronizado utilizado pelo INSS para dizer quem é a pessoa com deficiência elegível ao BPC devem ser compreendidos para além de uma simples ineficácia do questionário. As controvérsias em torno das categorias incapacidade para a vida independente e para o trabalho podem comprometer os princípios éticos do BPC como uma política pública de responsabilidade do Estado em atender uma demanda de justiça social, o que representa uma disputa política e de fundo público em torno da política.

Segundo Diniz et. al (2007, p. 14), "quanto mais padronizada for a seleção, maiores as chances de objetividade no acesso ao programa e menores os riscos de idiossincrasias pessoais dos avaliadores interferirem na elegibilidade". Com isso, os critérios nãopadronizados utilizados pelos peritos para dizer quem é elegível ao BPC comprometem os fundamentos éticos em que o BPC está amparado por dispor de mecanismos discricionários, o que torna a concessão do benefício vinculada à compreensão pessoalizada que cada perito tem sobre quais devem ser as deficiências atendidas pelo BPC.

Com o objetivo de tornar mais abrangente o conceito de deficiência, utilizado como critério para acessar o BPC, ficou instituído pelo Decreto $n^{0} \cdot 6.214 / 2007$, que a concessão do benefício à pessoa com deficiência ficará sujeita à avaliação da deficiência e do grau de incapacidade com base nos princípios da Classificação Internacional de Funcionalidades, Incapacidade e Saúde (CIF) e, ainda, que a avaliação da deficiência e do grau de incapacidade será composta de avaliação médica e social que serão realizadas, respectivamente, pela perícia médica e pelo serviço social do INSS (BRASIL, 2007b).

A inclusão da avaliação social como integrante da avaliação de incapacidade da pessoa com deficiência era uma reivindicação dos movimentos sociais das pessoas com deficiência, do meio acadêmico e dos gestores da política de assistência social (SPOSATI, 2008). Foi, sobretudo, uma luta do Serviço Social do INSS, do Ministério do Desenvolvimento Social e Combate à Fome (MDS), defendida pelo Conselho Federal de Serviço Social (CFESS). Passou-se, então, a defender uma avaliação social que considerasse as relações sociais e econômicas das pessoas com deficiência em sua totalidade, o que significa reconhecer as condições de vida individuais e familiares, as possibilidades objetivas e subjetivas de acesso ao emprego e à renda e as (im)possibilidades de estabelecimento de uma dinâmica de vida que garanta direitos básicos como trabalho, moradia, lazer, educação. 
Por muitos anos se trava o debate da avaliação social como elemento essencial para o acesso ao BPC para as pessoas com deficiência no Brasil. As entidades representativas dos assistentes sociais foram protagonistas nesse debate e depois de forte movimento em defesa da reestruturação do Serviço Social no INSS, conseguem a publicação de um Edital em 2008, no âmbito do Ministério da Previdência Social, em que houve uma oferta de 900 vagas para o cargo de Analista do Seguro Social com formação em Serviço Social para suprir uma carência de assistentes sociais no INSS como reflexo da ausência de vinte anos de concursos no órgão. Dentre as atividades destinadas às assistentes sociais, estavam: 1 . prestar atendimento e acompanhamento aos usuários dos serviços prestados pelo INSS e aos seus servidores, aposentados e pensionistas; 2. elaborar, executar, avaliar planos, programas e projetos na área de Serviço Social e Reabilitação Profissional; 3. realizar avaliação social quanto ao acesso aos direitos previdenciários e assistenciais; 4. promover estudos sócio-econômicos visando a emissão de parecer social para subsidiar o reconhecimento e a manutenção de direitos previdenciários, bem como a decisão médicopericial; 5. executar de conformidade com a sua área de formação as demais atividades de competência do INSS.

Atualmente, no Distrito Federal, há um conjunto de dez assistentes sociais, todas mulheres, responsáveis pela realização da avaliação social para acesso ao BPC. Neste estudo, o enfoque será na atribuição das assistentes sociais do INSS especificamente para realizar avaliação social quanto ao acesso ao BPC.

Este Trabalho de Conclusão de Curso (TCC) do Departamento de Serviço Social (SER) do Instituto de Ciências Humanas (IH) da Universidade de Brasília (UnB) tem como objetivo compreender em que medida o processo de avaliação social, realizado pelas assistentes sociais do INSS para a concessão do BPC, pode contribuir para ampliar o acesso ao benefício e superar as concepções restritas de deficiência e de incapacidade para o trabalho e para a vida independente. Quais os desafios do processo da avaliação social tendo em vista as concepções restritivas da perícia médica sobre deficiência e grau de incapacidade? Para responder a essa pergunta de pesquisa, foram realizadas entrevistas com as assistentes sociais responsáveis em realizar a avaliação social para acesso ao BPC para as pessoas com deficiência. A partir das entrevistas, foi possível conhecer os desafios do processo de avaliação social de responsabilidade das assistentes sociais.

No seu conjunto, o TCC está dividido em três capítulos. O primeiro apresenta uma discussão em relação ao fenômeno da deficiência, mostrando o debate dos modelos médico e social da deficiência, bem como uma análise da deficiência no contexto brasileiro. Neste capítulo, também buscamos refletir em torno do debate sobre a pessoa com deficiência a partir da Antiguidade e conhecer os termos e conceitos utilizados ao longo da História. 
O segundo capítulo consiste em reflexões sobre o BPC nos seus quatorze anos de existência. Neste capítulo, procuramos apresentar o BPC, esclarecendo sua origem e destacando informações quantitativas quanto à demanda atendida, assim como procuramos oferecer dados comparativos do benefício com o IBGE e entre os segmentos das pessoas com deficiência que demandam o benefício. Buscamos fazer um levantamento da trajetória da operacionalização do BPC, com o intuito de recuperar a construção das orientações normativas do caminho operativo do benefício desde a sua origem até o ano de 2010 e, dessa forma, poder traçar os elementos constitutivos da lógica sustentadora deste caminho. O capítulo dois também traz o debate em torno do processo de avaliação social para acesso ao BPC, um instrumento que queremos saber se contribui para a ampliação do acesso ao benefício pelas pessoas com deficiência.

O terceiro capítulo busca conhecer o trabalho do/a assistente social no âmbito do INSS. Inicialmente, conhecemos um pouco do conhecido Serviço Social previdenciário a partir da década de 1940. No segundo momento, realizamos uma análise das entrevistas com as assistentes sociais que realizam a avaliação social para o acesso ao BPC para pessoas com deficiência no DF. Neste capítulo, buscamos: 1. avaliar quais as principais mudanças provocadas no processo de acesso ao BPC com a utilização da avaliação social realizada pelo Serviço Social nas agências do INSS; 2 . discutir as dificuldades e os desafios postos às assistentes sociais no processo de avaliação social em relação às questões éticas, materiais e técnicas do trabalho profissional, considerando as condições de trabalho, os princípios ético-políticos do Serviço Social e os princípios da CIF. Após o terceiro capítulo, encontram-se as considerações finais. 


\section{JUSTIFICATIVA}

A CF/1988 concebe a assistência social como direito social (BRASIL, 1988). Serviço Social, por sua vez, adota como um dos mais importantes princípios no Código de Ética do Assistente Social (1993) a afirmação, ampliação e consolidação da cidadania, considerada tarefa primordial de toda sociedade, com vistas à garantia dos direitos civis, sociais e políticos das classes trabalhadoras (CFESS, 1993).

Segundo lamamoto (2008), a política pública de assistência social no marco da seguridade social tem sido um dos âmbitos privilegiados de atuação profissional e um dos temas de destaque no Serviço Social brasileiro recente. O debate sobre as políticas sociais vem oferecendo uma sólida sustentação teórica à qualificação da assistência social no âmbito das relações entre o Estado e a sociedade civil, como direito dos cidadãos que dela necessitam e dever do Estado.

Há um consenso entre os autores da área de assistência social sobre a posição secundária que essa política vem tradicionalmente ocupando nas políticas públicas, com ações tangenciais às demais políticas e terreno fértil ao clientelismo. Contudo, sendo a assistência social uma das estratégias reguladoras das condições de reprodução social da classe trabalhadora, é campo de acesso a bens e serviços, podendo ser um espaço de reiteração da subalternidade ou meio de abancar na construção da cidadania (IAMAMOTO, 2008).

A assistência social tem sido um dos principais campos sócio-ocupacionais, em que o profissional realiza uma mediação fundamental para acesso a direitos. $O$ assistente social dispõe de uma dupla função: é o intermediador direto das necessidades dos usuários mediante a prestação de serviços assistenciais e responde pelo componente sócioeducativo que o informa. Ele é demandado para dar conta do mecanismo assistencial que permeia as políticas de corte social, fazendo frente a uma diversificada demanda de ações assistenciais (YAZBEK, 1993; IAMAMOTO, 2008).

Este TCC surgiu de duas experiências distintas: 1. por meio da inserção no Grupo de Estudos e Pesquisas sobre Seguridade Social e Trabalho (GESST), onde pesquisa-se as tendências contemporâneas das políticas de previdência social, assistência social e saúde no contexto da América Latina; 2. por meio do campo de estágio na Anis - Instituto de Bioética, Direitos Humanos e Gênero, onde foi feito o projeto de intervenção na área do BPC e houve uma aproximação no debate sobre a deficiência, na intenção de descrever como a CIF foi incorporada nos programas de previdência e assistência social por meio de levantamento junto aos médicos-perito do INSS. No entanto, não havia qualquer publicação sobre o trabalho dos assistentes sociais no processo de avaliação social do BPC, pois esta 
é uma atribuição recente no âmbito do exercício profissional.

Com pesquisas realizadas no campo de estágio, observaram-se várias mudanças nos critérios de acesso ao BPC que é o único benefício assistencial previsto na CF/1988 e para onde é destinada a maior parte dos recursos do FNAS (BOSCHETTI e SALVADOR, 2006).

Uma dessas mudanças para a concessão do benefício à pessoa com deficiência ficou sujeita à avaliação da deficiência e do grau de incapacidade, com base nos princípios da CIF, estabelecida pela Resolução da Organização Mundial da Saúde $n^{0}$. 54.21, aprovada pela $54^{\mathrm{a}}$. Assembléia Mundial da Saúde, em 22 de maio de 2001. Essa avaliação da deficiência e do grau de incapacidade será composta de avaliação médica e social, sendo que deverão ser observados os fatores ambientais, sociais e pessoais, considerando a limitação do desempenho de atividades e a restrição da participação social, segundo suas especificidades. As avaliações serão realizadas pela perícia médica e pelo Serviço Social do INSS, por meio de instrumentos desenvolvidos especificamente para este fim (BRASIL, 2007).

Diante dessa nova e importante atribuição profissional no INSS, bem como a incipiente produção de conhecimento sobre o processo de avaliação social, surgiu o interesse em estudar como se dá o processo de avaliação social que é realizado pelo Serviço Social do INSS. É de grande preocupação conhecer como está sendo operacionalizado esse serviço, haja vista que o BPC é o mais importante benefício constitutivo da política de assistência social no Brasil.

Toda política social necessita de acompanhamento em seu processo de formulação e implantação, não só para avaliar sua capacidade de ampliar direitos sociais, mas, sobretudo, para compreender sua potencialidade (ou não) de atuar para reduzir desigualdades. Assim, compreender se o processo de avaliação social pode tencionar os critérios restritos que avaliam a deficiência e o grau de incapacidade e impedem o acesso de pessoas com deficiência ao BPC poderá trazer contribuições para o Serviço Social e para possíveis alterações no funcionamento do programa, com o objetivo de ampliar o acesso e promover a garantia dos direitos sociais às pessoas com deficiência no Brasil.

A perspectiva deste TCC é de valorização do BPC como direito de assistência social para idosos e pessoas com deficiência pobres no país. O BPC, na literatura de algumas das áreas do conhecimento que tratam de políticas públicas e sociais, vem sendo transformado em um símbolo de política social focalizada, de garantia apenas dos mínimos de sobrevivência dos beneficiados e de alcance ainda restrito no combate à pobreza (SPOSATI, 2008; PEREIRA, 2006). No entanto, é importante salientar que a persistência nas literaturas sobre o BPC apenas como exemplo de política social com alcance restrito 
pode contribuir para posicionar ao segundo plano a necessidade de estudos que tratam da análise da implantação e acompanhamento do BPC, o que fragiliza ainda mais o benefício e compromete seu alcance.

Portanto, analisar a operacionalidade da avaliação social para acesso ao BPC para pessoas com deficiência, verificando se seguem na direção de expandir ou de reduzir os direitos, é importante para a formação profissional como assistente social, uma vez que a profissão lida diretamente com a temática das políticas sociais como garantia de cidadania, principalmente, lutando para universalização dos direitos sociais, fazendo-se necessário compreender a tendência que permeia o estabelecimento desse tipo de política hoje no Brasil. 


\title{
METODOLOGIA
}

\section{Método e Técnica da Pesquisa}

A metodologia é o "caminho pelo qual o pesquisador se guia para ter aproximações sucessivas da realidade" (BEHRING e BOSCHETTI, 2006, p. 42), com a intenção de compreendê-la e desvendá-la. Este trabalho parte desta concepção de metodologia que é orientada pela "contribuição da tradição marxista" (BEHRING e BOSCHETTI, 2006, p. 36) para a abordagem da política social, que promoveu uma guinada do ponto de vista da relação sujeito-objeto:

\begin{abstract}
uma perspectiva relacional, numa análise das políticas sociais como processo e resultado de relações complexas e contraditórias que se estabelecem entre Estado e sociedade civil, no âmbito dos conflitos e luta de classes que envolvem o capitalismo e recusa a utilização de enfoques restritivos ou unilaterais, comumente presentes para explicar sua emergência, funções ou implicações (BEHRING e BOSCHETTI, 2006, p. 36).
\end{abstract}

Como consequências dessa perspectiva para a relação sujeito/objeto, Behring e Boschetti (2006) revelam a existência de um sujeito ativo, inquieto, que indaga o objeto, procurando extrair o que se passa nele, seu movimento real. Por meio da análise da política social pela tradição marxista, sujeito e objeto são situados de forma que não há nenhuma perspectiva de neutralidade, reconhecendo as visões sociais do mundo que impregnam sujeito e objeto.

Neste trabalho, a metodologia utilizada adota como referência o método materialismo histórico e dialético marxista para compreender a sociedade. Tal concepção apresenta bases materialistas, ou seja, admitindo a hegemonia da matéria, na reprodução das relações sociais de produção, em relação às ideias, nas quais as contradições se transcendem, mas dão origem a novas contradições que passam a requerer solução (GIL, 2000).

Aqui problematiza-se o surgimento e o desenvolvimento das políticas sociais no contexto da acumulação capitalista e da luta de classes, com a perspectiva de demonstrar seus limites e possibilidades na produção do bem-estar nas sociedades capitalistas (MISHRA apud BEHING e BOSCHETTI, 2006, p. 37). Procuramos nos desprender das análises unilaterais sobre o BPC que o situam ora "a emergência de política social como uma das iniciativas exclusivas do Estado para responder a demandas da sociedade e garantir hegemonia" (BEHRING e BOSCHETTI, 2006, p. 37), ora para "explicar a existência das políticas como decorrência da luta e pressão da classe trabalhadora" (BEHRING e BOSCHETTI, 2006, p. 37). 
Não que essas análises estejam erradas, mas, no entendimento de Behring e Boschetti (2006),

\begin{abstract}
são insuficientes e unilaterais porque não exploram as contradições inerentes aos processos sociais, não reconhecem que as políticas sociais podem ser centrais na agenda de lutas dos trabalhadores e no cotidiano de suas vidas, quando conseguem garantir ganhos para os trabalhadores e impor limites aos ganhos do capital (2006, p. 37-38).
\end{abstract}

O método crítico de Marx consiste em situar e analisar os fenômenos sociais em seu complexo e contraditório processo de produção e reprodução, determinado por múltiplas causas na perspectiva de totalidade e inseridos na totalidade concreta: a sociedade burguesa (BEHRING e BOSCHETTI, 2006, p. 38). Isso revela a condição histórica e social da política social extraída do movimento da sociedade burguesa, numa perspectiva crítica, histórica e ontológica, sendo o ponto central dessa linha de análise reproduzir idealmente o movimento real do objeto pelo sujeito, extrair do objeto as suas características e determinações, reconstruindo-o no nível do pensamento como um conjunto rico de determinações que vão além das suas sugestões imediatas.

A investigação marxista caracteriza-se por não se deixar enganar por aspectos e semelhanças superficiais presentes nos fatos, procurando chegar à essência do fenômeno (MARX apud BEHRING e BOSCHETTI, 2006). É nessa perspectiva que se situa a análise do BPC neste trabalho, não sendo percebidas apenas em sua expressão fenomênica, buscando capturar o seu movimento essencial na sociedade burguesa.

Por meio desse método, analisamos o processo de avaliação social para acesso ao BPC em suas múltiplas dimensões e determinações, não se contentando com os esquemas abstratos de explicação, nem com as simples e evidentes representações do senso comum. Buscamos desvendar o significado real das políticas que se esconde sob o mundo fenomênico da aparência. Isso revela que

não consideramos as políticas sociais como produtos fixos, como objetos reificados, como algo independente e a-histórico. Não aceitamos seu aspecto imediato e aparente. Ao contrário, esse pensamento utiliza o método dialético materialista que permite compreender e revelar que as formas reificadas se diluem, perdem sua rigidez e naturalidade para se mostrar como fenômenos complexos, contraditórios e mediados, campo produtos da práxis social da humanidade (BEHRING e BOSCHETTI, 2006, p. 43).

Nessa perspectiva, o estudo das políticas sociais deve considerar sua múltipla causalidade, as conexões internas, as relações entre suas diversas manifestações e dimensões.

Para realizar esta pesquisa, buscamos seguir os passos de Netto (2009) que aponta três momentos importantes no processo de pesquisa. Em primeiro lugar, o profissional 
necessita possuir uma visão global da dinâmica social concreta, precisa conjugar o conhecimento do modo de produção capitalista com a sua particularização na nossa sociedade. Após, o autor afirma que é preciso encontrar as principais mediações que vinculam o problema específico que se ocupa com as expressões gerais assumidas pela "Questão Social"" no Brasil contemporâneo e com as várias políticas sociais que se propõem a enfrentá-las. E por fim, o autor afirma que o profissional deve apropriar-se criticamente do conhecimento existente sobre o problema específico com o qual se ocupa, sendo necessário dominar a bibliografia teórica, a documentação legal, a sistematização de experiências, as modalidades das intervenções institucionais e instituintes, as formas e organizações de controle social, o papel e o interesse dos usuários e dos sujeitos coletivos envolvidos.

Esses três momentos não configuram "operações intelectivas sucessivas: são passos constitutivos do processo pelo qual o profissional pode desenvolver de fato uma atitude investigativa numa perspectiva compatível com o espírito do método de Marx" (NETTO, 2009, p. 695).

Não se pretende conhecer todos os aspectos da realidade que perpassa o processo de avaliação social para o acesso ao BPC, mas por meio de aproximações sucessivas, pretende-se "reconhecer o caráter histórico do fenômeno, conhecer o conteúdo objetivo e do significado do fenômeno, de sua função objetiva e de seu lugar histórico" (KOSIK apud BEHRING e BOSCHETTI, 2006, p. 42).

Este estudo será realizado por meio da pesquisa qualitativa, que privilegia análises interpretativas, que tem como objetivos "descobrir conceitos e relações nos dados brutos e de organizar esses conceitos e relações em um esquema explanatório teórico" (STRAUSS e CORBIN, 2008, p. 24). Trata-se, portanto, de uma pesquisa qualitativa de cunho exploratório.

Dentro das abordagens metodológicas de pesquisa qualitativa, foi selecionada uma técnica de pesquisa, a entrevista semi-estruturada (CRESWELL, 2007). A entrevista semiestruturada é uma técnica de entrevista guiada por um roteiro que apresenta uma lista de perguntas a serem respondidas (COMBESSIE, 2004). As perguntas são elaboradas de modo a obter na resposta dos participantes, os dados da realidade estudada. A entrevista

2 Nesse trabalho, a expressão "Questão Social" é utilizada para designar o processo de politização da desigualdade social inerente à constituição da sociedade burguesa. Sua emergência vincula-se ao surgimento do capitalismo e à pauperização dos trabalhadores, e sua constituição, enquanto questão política, é datada da primeira metade do século XIX, como resultado das lutas operárias, donde o protagonismo político da classe trabalhadora - à qual se creditou a capacidade de tornar públicas as suas precárias condições de vida e trabalho, expondo as contradições que marcam historicamente a relação entre o capital e o trabalho. A "Questão Social" é a razão de ser do Serviço Social, referendada como o elemento que dá concretude à profissão de assistente social de acordo com a Proposta Básica para o Projeto de Formação Profissional, é a base da sua fundação histórico-social na realidade brasileira, devendo ser a sua compreensão e análise estruturadoras dos conteúdos da formação profissional (MOTA, 2010a). 
semi-estruturada busca manter em seu desenvolvimento uma lógica provável dos encadeamentos e para isso utiliza-se de recursos como questões trampolim, que anunciam o tema a ser abordado criando uma dinâmica na entrevista (COMBESSIE, 2004). A entrevista semi-estruturada é um instrumento pelo qual o pesquisador se envolve com os participantes na coleta de dados e tenta estabelecer credibilidade com os participantes (CRESWELL, 2007).

A análise documental, outra técnica utilizada nesse trabalho, é importante para a pesquisa em ciências sociais e humanas porque "é uma das técnicas de maior confiabilidade" (GODOY, 1995, p. 21). Essa técnica apresenta-se como uma técnica de verificação de dados, visa o acesso às fontes pertinentes, escritas ou não, sendo parte integrante da heurística da investigação. É uma técnica que tanto complementa informações obtidas por outras técnicas, quanto revela aspectos novos de um tema ou problema. A análise documental é uma técnica importante porque a investigação histórica, ao pretender estabelecer sínteses sistemáticas dos acontecimentos históricos, contribui às ciências sociais no sentido da reconstrução crítica de dados que permitam inferências e conclusões (COHEN e MANION, 1990).

Esta pesquisa, então, apresentou as seguintes etapas metodológicas: 1 . levantamento bibliográfico da literatura sobre o BPC, Assistência Social, Deficiência e Avaliação Social; 2. análise documental das categorias em análise; 3. trabalho de campo: a) construção de um instrumento de coleta de dados para a realização das entrevistas; b) realização de cinco entrevistas com as assistentes sociais responsáveis pela avaliação social no Distrito Federal com gravação de voz das entrevistadas; 4. transcrição das entrevistas e análise qualitativa dos dados.

As entrevistas tiveram como objetivo captar o processo de trabalho, em seus aspectos técnicos, materiais e éticos, as dificuldades e os desafios no processo de avaliação social para acesso ao BPC.

\section{Universo da Pesquisa}

O então Presidente do Instituto Nacional do Seguro Social - INSS, Marco Antônio de Oliveira, tendo em vista a Portaria $n^{0}$. 108, de 14 de maio de 2008, do Ministério do Planejamento, Orçamento e Gestão (MPOG), publicada no Diário Oficial da União (D.O.U.), de 15 de maio de 2008, republicada no D.O.U., de 16 de maio de 2008, tornou pública a realização de concurso público para provimento de 900 vagas e formação de cadastro de reserva para o cargo de Analista do Seguro Social com formação em Serviço Social, em conformidade com a Lei $n^{0}$. 8.112, de 11 de dezembro de 1990 e suas alterações 
posteriores, com a Portaria $n^{0} .450$, de 6 de novembro de 2002, do MPOG, e com a Lei $n^{0}$. 10.355, de 26 de dezembro de 2001, e suas alterações posteriores, após vinte anos sem concursos na área para o referido órgão. O resultado final do concurso público foi homologado no D.O.U. do dia 04 de junho de 2009, seção 3, página 98.

No Distrito Federal, baseado no D.O.U. de 04 de junho de 2009, há vinte e quatro assistentes sociais na lista dos aprovados e classificados. Segundo o Edital $n^{0}$. 1/2008, havia doze vagas, sendo uma para pessoa com deficiência. Os doze assistentes sociais para além das vagas, formam um cadastro de reserva para possíveis convocações futuras.

O INSS se organiza por meio de Gerências Executivas (GEX). Há na GEX do Distrito Federal (DF), atualmente, um universo de 18 assistentes sociais: a) no Distrito Federal, há 3 no Plano Piloto, 2 em Taguatinga, 2 em Ceilândia, 1 no Gama, 1 em Planaltina, 1 em Sobradinho (DF=10); b) em Goiás (GO), há 1 em Posse, 1 em Luziânia, 1 em Unaí e 1 em Formosa $(\mathrm{GO}=4)$. Existe ainda uma assistente social empossada no DF que foi para a superintendência regional e 3 que estão na Divisão de Serviço Social (DSS).

\section{Análise dos dados}

As dificuldades e os desafios vivenciados pelas assistentes sociais na realização da avaliação social, com vistas à concessão do BPC foram analisados qualitativamente a partir do conteúdo das entrevistas que foram aplicadas às assistentes sociais. Os dados levantados pelas entrevistas foram analisados sob a perspectiva de avaliação com base no Projeto Ético-Político hegemônico do Serviço Social, com as competências e atribuições asseguradas na Lei $n^{0}$. 8.662/1993.

Após a realização das entrevistas, as informações foram transcritas e iniciamos a fase de análise dos dados qualitativos das entrevistas. Foi realizada a transcrição por meio de uma leitura na íntegra de todas as entrevistas com o objetivo de construir uma grade temática com os desafios que se apresentam no processo de avaliação social.

Por fim, é importante entender que a utilização de metodologias e métodos, acrescidos de conhecimentos teóricos, é um guia importante para o pesquisador na análise da realidade. Os resultados dessa análise irão gerar novos conhecimentos da realidade social (STRAUSS e CORBIN, 2008). 


\section{CAPÍTULO 1}

\section{O DEBATE ACERCA DO FENÔMENO DA DEFICIÊNCIA}

\subsection{Introdução}

Exclusão e estigma. De acordo com Barbosa et. al (2009), a história da deficiência é indissociável dessas duas características. O corpo da pessoa com deficiência foi submetido a diferentes formas de controle, com discursos religiosos e biomédicos monopolizando os saberes sobre a deficiência nos últimos séculos.

A deficiência é um campo ainda pouco explorado no Brasil. Isso ocorre principalmente porque: 1. a deficiência ainda não se libertou da autoridade biomédica, com poucos cientistas sociais dedicando-se ao tema e 2. a deficiência ainda é considerada uma tragédia pessoal, e não uma questão de justiça social (DINIZ, 2007).

O debate sobre a deficiência encontra dificuldade em alcançar a esfera pública e sua atenção prevalece no âmbito familiar privado. O desafio em torno de justiça no campo da deficiência, na análise de Diniz (2007), está tanto em afirmar a deficiência como um estilo de vida, quanto em reconhecer a legitimidade de ações distributivas e de reparação da desigualdade em seus aspectos sociais e de cuidados biomédicos.

A deficiência é um tema emergente para as políticas públicas, particularmente as de caráter distributivo e de proteção social (MEDEIROS et. al, 2006). O ponto de partida das negociações políticas deve ser o trato da deficiência como instrumento de justiça social, e não somente como questão familiar ou individual. Nesse sentido, é importante saber o que é a deficiência, uma terminologia que ainda se encontra num patamar de imprecisão conceitual.

\subsection{Termos, Definições e Conceitos sobre a Deficiência}

Ao longo dos séculos, os termos que geralmente empregamos para designar as pessoas com deficiência estiveram carregados preconceitos e discriminações, intensificados pela noção de que a condição em que as pessoas com deficiência se encontram é imutável. Os conceitos apontam para ideias deterministas, provocando emoções que vão desde a compaixão até a rejeição, o que contribui para uma espécie de desesperança a respeito das possíveis mudanças. Certo é que cada novo termo vem acompanhado da justificativa de ampliar o conceito de deficiência, na intenção de evitar conotações pejorativas. 
Vários são os termos para se referir às pessoas que têm algum tipo de deficiência. $O$ debate científico sobre a deficiência informa que ninguém porta ou carrega sua deficiência, apenas a tem (DINIZ, 2007). Nesse momento, queremos problematizar no sentido de conhecer qual é o termo apropriado - portador de deficiência, pessoa portadora de deficiência ou portador de necessidades especiais ou outro termo - para ser utilizado entre as pessoas que possuem alguma deficiência.

Isso é de difícil resposta. Vários autores afirmam que não existe um único termo correto, válido definitivamente. A razão disto reside no fato de que a cada época são utilizados termos cujo significado seja compatível com os valores vigentes em cada sociedade enquanto esta evolui em seu relacionamento com as pessoas que possuem uma deficiência.

O termo deficiente é originário do latim deficiens, o que significa insuficiente, insatisfatório, medíocre. O termo é um adjetivo atribuído a uma pessoa que tem diminuídas as faculdades físicas ou intelectuais.

O portador de necessidades especiais é um termo mais utilizado pelo sistema educacional, quando quer referir-se a alunos com necessidades educativas especiais. Segundo Diniz (2007), esse termo é muito amplo porque uma pessoa que usa óculos, por exemplo, tem uma necessidade especial.

Tão difícil quanto apontar um termo apropriado para as pessoas que sofrem opressão pelo corpo, é definir o que é a deficiência. O modelo hegemônico foi o biomédico que, de acordo com Diniz (2007), define a deficiência com uma característica individual, uma anomalia humana que deve ser tratada, reconhecendo na lesão a primeira causa da desigualdade social e das desvantagens vivenciadas pelas pessoas com deficiência, ignorando o papel das estruturas sociais que fundamentam o sentido de exclusão, de estigma e de não pertencimento.

No entanto, houve uma evolução no entendimento da concepção de deficiência nas últimas décadas, sobretudo das condições sociais e dos direitos sociais referentes às pessoas com deficiência, bem como das responsabilidades do poder público e da sociedade.

As legislações são importantes meios para a garantia dos direitos das pessoas com deficiência, principalmente no que se refere à inserção ao mundo do trabalho, à saúde, à educação, dentre outros direitos sociais necessários para a reparação das desigualdades daqueles que experimentam a deficiência. Nesse sentido, essas legislações precisavam informar quem era a pessoa com deficiência.

A LOAS/1993 aponta que a pessoa com deficiência é aquela incapacitada para a vida independente e para o trabalho, um conceito que permite identificar qual a pessoa com 
deficiência possui o direito ao BPC.

O Decreto $n^{0}$. 1.744/1995, que regulamentava o BPC, definiu como pessoa com deficiência "aquela incapacitada para a vida independente e para o trabalho em razão de anomalias ou lesões irreversíveis, de natureza hereditária, congênita ou adquirida que impeçam o desempenho das atividades da vida diária e do trabalho" (BRASIL, 1995). Decreto de 1995 restringiu o conceito ao colocar a irreversibilidade da lesão ou anomalia e ao definir como sinônimo de incapacidade de vida independente o não desempenho das atividades da vida diária e do trabalho.

A Resolução n ${ }^{0}$. 48/1996 da Organização das Nações Unidas (ONU), que aprovou as Normas Uniformes sobre a Igualdade de Oportunidades para Pessoas Portadoras de Deficiência, em seu art. 17, considera como deficiência "a perda ou limitação de oportunidades de participar da vida comunitária em condições de igualdade com as demais pessoas" (ONU, 1996). Essa Resolução já apontou a necessidade da participação social, teve como objetivo conscientizar sobre a importância da adequação do meio físico capaz de propiciar uma participação social em condições de igualdade com os demais cidadãos.

Já na Convenção Interamericana para a Eliminação de todas as Formas de Discriminação contra as Pessoas Portadoras de Deficiência, de 28 de maio de 1999, a Convenção da Guatemala, deficiência significa "uma restrição física, mental ou sensorial, de natureza permanente ou transitória, que limita a capacidade de exercer uma ou mais atividades essenciais da vida diária, causada ou agravada pelo ambiente econômico e social" (CONVENÇÃO DA GUATEMALA, 2006).

O Decreto $n^{0}$. 3.298/1999 definiu deficiência como sendo "perda ou anormalidade de uma estrutura ou função psicológica, fisiológica ou anatômica, que gere incapacidade para o desempenho de atividades, dentro do padrão considerado normal para o ser humano" (BRASIL, 1999). Esse Decreto considera pessoa com deficiência aquela que apresenta, em caráter permanente, perdas ou anormalidades de sua estrutura ou função psicológica, fisiológica ou anatômica, que gerem incapacidade para o desempenho de atividades dentro do padrão considerado normal para o ser humano. Aqui há uma aproximação latente de um conceito moral embasado na normalidade.

A Convenção $n^{0} .159$ da Organização Internacional do Trabalho (OIT), que trata da readaptação profissional e do emprego de pessoas com deficiência, ratificada pelo Brasil, conceitua pessoa com deficiência como "toda pessoa cujas perspectivas de conseguir e manter um emprego conveniente e de progredir profissionalmente são sensivelmente reduzidas em virtude de uma deficiência física (aqui incluídas as deficiências sensoriais) ou mental devidamente reconhecida" (OIT, 2001).

O Decreto $n^{0}$. 3.956/2001 aplica uma definição mais ampla de deficiência: "restrição 
física, mental ou sensorial, de natureza permanente ou transitória, que limita a capacidade de exercer uma ou mais atividade essencial da vida diária, causada ou agravada pelo ambiente econômico e social" (BRASIL, 2001). A deficiência, portanto, diz respeito à alteração em um órgão ou estrutura do corpo humano que resulta nas restrições citadas, limitando a capacidade de exercer atividades da vida diária, causada ou agravada pelo ambiente, envolvendo também aspectos sociais e econômicos.

De acordo com o Decreto $n^{0}$. 5.296, de 02 de dezembro de 2004, pessoas com deficiência são aquelas que possuem limitações ou incapacidades para o desempenho de atividades. As limitações são enquadradas tecnicamente em categorias: a) deficiência física; b) deficiência auditiva; c) deficiência visual; d) deficiência mental; e) deficiência múltipla (BRASIL, 2004).

Em nível mundial, os movimentos sociais de pessoas com deficiência estão em debate para identificar qual o termo que as pessoas com deficiência desejam ser reconhecidas. A nomenclatura sugerida pela ONU, por meio da Convenção Internacional para Proteção e Promoção dos Direitos e Dignidade das Pessoas com Deficiência, assinado em Nova York em 2007, para caracterizar uma pessoa com deficiência passou a ser apenas "pessoa com deficiência".

No Brasil, o texto da Convenção de 2007 da ONU, que trata sobre os direitos das pessoas com deficiência, foi aprovado por meio do Decreto Legislativo $\mathrm{n}^{0}$. 186, de 9 de julho de 2008. A Convenção, conforme o procedimento do $\S 3^{\circ}$. do Art. $5^{0}$. da CF/1988, é equivalente à emenda constitucional, uma vez que se trata de uma convenção internacional sobre direitos humanos que foi aprovada, em cada Casa do Congresso Nacional, em dois turnos, por três quintos dos votos dos respectivos membros.

Em 2009, a Convenção foi, então, promulgada no Brasil por meio do Decreto $\mathrm{n}^{0}$. 6.949, de 25 de agosto de 2009 e possui status de Constituição. O Decreto afirma que

Art. 1‥ Pessoas com deficiência são aquelas que têm impedimentos de longo prazo de natureza física, mental, intelectual ou sensorial, os quais, em interação com diversas barreiras, podem obstruir sua participação plena e efetiva na sociedade em igualdades de condições com as demais pessoas (BRASIL, 2009b).

Esse Decreto de 2009 defende um conceito de deficiência de acordo com a evolução histórica e as diferentes dimensões presentes (biológica, econômica, social, política, cultural), entendendo a deficiência em sua complexidade e em suas multideterminações.

Os princípios básicos para se chegar ao termo pessoas com deficiência são: 1. não esconder ou camuflar a deficiência; 2. não aceitar o consolo da falsa ideia de que todo mundo tem deficiência; 3. mostrar a realidade da deficiência; 4. valorizar as diferenças e necessidades decorrentes da deficiência; 5. combater neologismos e expressões que 
tentam diluir as diferenças, tais como "pessoas com capacidades especiais", "pessoas com deficiências diferentes", "pessoas com habilidades diferenciadas", "pessoas deficientes", "pessoas especiais", "é desnecessário discutir a questão das deficiências porque todos nós somos imperfeitos"; 6. defender a igualdade entre as pessoas com deficiência e as demais pessoas em termos de direitos e dignidade, o que exige a equiparação de oportunidades para pessoas com deficiência atendendo às diferenças individuais e necessidades especiais, que não devem ser ignoradas; 7. identificar nas diferenças todos os direitos que Ihes são pertinentes e a partir daí encontrar medidas específicas para o Estado e a sociedade diminuírem ou eliminarem as "restrições de participação" (dificuldades ou incapacidades causadas pelos ambientes humano e físico contra as pessoas com deficiência).

Wendell (1996) informa sobre a necessidade de avançar na definição de deficiência, a fim de incorporar no debate, por exemplo, as experiências de doenças crônicas que limitam as atividades das pessoas. De acordo com a autora, as maiores causas de deficiências nos países de "primeiro mundo" são em pessoas idosas e por doenças crônicas, como: artrite, reumatismo, problemas do coração e respiratórios, mal de Parkinson, hipertensão e epilepsia.

Por fim, é importante debater a definição de deficiência, pois isso contribui para o reconhecimento das pessoas com deficiência como seres humanos e para a organização política a fim de pressionar o Estado para garantir um efetivo acesso aos direitos sociais para todos que sofrem opressão pelo corpo.

\subsection{A Pessoa com Deficiência no Curso da História}

Foi somente após a Segunda Guerra Mundial, principalmente devido à reabilitação dos soldados americanos feridos, que as pessoas com deficiência começaram a entrar na agenda de debates nas ciências sociais, embora ainda de forma incipiente. Por mais de vinte séculos, as pessoas com deficiência foram invisíveis, segregadas, excluídas, discriminadas (CLEMENTE, 2004).

Nas sociedades pré-capitalistas, o desenvolvimento das forças produtivas não mercantilizado pelo capital foi a característica principal das sociedades primitivas, o que levava a grande maioria dos homens a viverem no nomadismo, em que suas condições de existência estavam totalmente na dependência do que a natureza lhes proporcionava, ou seja, a coleta de frutos, a caça e a pesca, no que se refere à alimentação, e as cavernas no tocante a abrigos. Devido ao caráter cíclico da natureza naquela época, os deslocamentos do grupo eram constantes. "Em função desta prática, abandonavam aqueles que não 
pudessem mover-se com agilidade, ou que tivessem alguma diferença que impedisse sua mudança de um lugar para outro com rapidez" (BIANCHETTI, 1998, p. 27). Dentre estes abandonados, encontravam-se pessoas com deficiência.

De acordo com Silva (1986), existiam alguns destinos para as pessoas com deficiência na Antiguidade. Nos lugares onde ocorria grande concentração humana, as pessoas com deficiência eram utilizadas para mendigar ou para serem ridicularizadas em espetáculos circenses, passando a ter algum valor mercantil. $\mathrm{Na}$ intenção de explorar as pessoas com deficiência, "existia em Roma um mercado especial para compra e venda de homens sem pernas ou braços, de três olhos, gigantes, anões, hermafroditas" (DURANT apud SILVA, 1986, p. 130).

No entanto, ainda na Antiguidade, as pessoas com deficiência, em alguns lugares, eram consideradas inúteis e amaldiçoadas, motivos que as levavam à morte. As leis romanas autorizavam os pais a matarem os filhos com deficiência. Na Grécia, as pessoas com deficiência eram lançadas em abismos, pois contrariavam as expectativas da sociedade que cultivava os ideais da estética corporal (SASSAKI, 1997).

É na Idade Média que ocorreu uma guinada no tratamento daqueles que tinham alguma deficiência. A Igreja Católica começa a difundir que todas as pessoas eram criaturas de Deus, assim, as pessoas com deficiência deixavam de ser mortas para serem abandonadas ou dependentes da caridade alheia para garantir sua sobrevivência. As pessoas com deficiência eram abrigadas nas casas de assistência médica, pois agora elas "mereciam" atenção caritativa, eram objetos merecedores de algum tipo de cuidado (SILVA, 1986).

Com a expansão marítima e comercial do século XVI, as pessoas com deficiência passavam despercebidas ou ficavam isoladas em casas de saúde, fundadas por ordem do rei ou por conservatórios das Igrejas Jesuíticas. Naquela época, elas desempenhavam funções escravocratas, envolvendo trabalhos manuais ou permaneciam recolhidas por pessoas que se sensibilizavam as suas vulnerabilidades.

A mitologia, o espiritismo e a bruxaria dominaram a discussão sobre as pessoas com deficiência nos séculos XVI e XVII, quando elas eram submetidas a perseguições e encarceramentos, demonstrando claramente os valores da ordem social e seus violentos mecanismos de controle social (SILVA, 1986). Esse modelo místico começou a ser contestado a partir das descobertas geográficas do final da primeira metade do segundo milênio que contribuíram para que ocorresse um gradativo aumento do mercado por produtos manufaturados, a possibilidade de maior acumulação de capitais e o desenvolvimento da ciência e da tecnologia, ampliando as condições do homem na luta para dominar a natureza. 
Essas transformações, que representaram o fim do feudalismo e o surgimento do modo de produção capitalista, fizeram com que, aos poucos, os tradicionais costumes medievais fossem perdendo força e, em seu lugar, nascesse a cultura da sociedade moderna. Com o modo de produção capitalista, as relações humanas passaram a ser organizadas em função de um processo produtivo voltado para a acumulação de lucros. Nesse modo de produção, aqueles que não se ajustam à lógica do sistema de exploração, passam a ser considerados como perturbadores da ordem social (HUBERMAN, 1995). Dentre estes, encontram-se as pessoas com deficiência que passaram a ser internadas em asilos, manicômios, hospícios. "O que ocorreu, na verdade, foi o isolamento daqueles que interferiam e atrapalhavam o desenvolvimento da nova forma de organização social, baseada na homogeneização e na racionalização" (SILVEIRA BUENO, 1993, p. 63).

O capitalismo traz profundas mudanças para as pessoas com deficiência. Como o custo da institucionalização e da segregação das pessoas com deficiência era caro para o Estado, inicia-se o discurso da autonomia e da produtividade das pessoas com deficiência. A exploração da força de trabalho também chega àqueles que outrora eram considerados inúteis.

Já no século $X X$, surgem vários inventos que materializaram a oferta de melhores meios de trabalho e locomoção para as pessoas com deficiência, tais como cadeiras de rodas e a escrita em Braille, o que contribuiu para a exploração, para melhoria da qualidade de vida e para lucrar junto ao contingente de mutilados das guerras.

Apenas em meados do século XX houve a preocupação com a inserção das pessoas com deficiência no mundo do trabalho. Segundo Cardoso (2006), esse fenômeno revelou a precariedade da assistência oferecida aos mutilados da guerra, sem condições de se sustentar e considerados não produtivos. Dessa época surge a ideologia da normalização, ideologia que pregava a necessidade de "inserir" a pessoa com deficiência na sociedade mais ampla, auxiliando-o a adquirir as condições e os padrões o mais próximo possível da vida cotidiana das demais pessoas (SILVA, 1986). Assim, começou-se a defender a ideia de que as pessoas com deficiência têm os direitos de qualquer cidadão, com qualidade de vida e inclusão no trabalho.

Estamos no século XXI e presenciamos a intensificação dos movimentos de defesa dos direitos das pessoas com deficiência, buscando atender suas necessidades e melhorar sua qualidade de vida. Apesar de todos os avanços, as pessoas com deficiência parecem ainda não existirem na sociedade. Eles seguem vivendo com uma noção de diferença relacionada com ideias de normalidade que se interpretam como divergências, infâmias, estereótipos, preconceitos ou discriminações.

Certo é que o ainda hegemônico modelo médico da deficiência tem uma parte de 
responsabilidade nessa realidade atual, está ligada a estereótipos ou preconceitos decorrentes da caracterização patológica de deficiência em todas as práticas gerais e narrativas que são utilizadas até hoje. O debate da "inclusão social" está na ordem do dia e busca nortear todo o sistema de proteção institucional das pessoas com deficiência no Brasil. É preciso que todos saibamos que as pessoas com deficiência foram tão negligenciadas ao longo da história que a luta delas é pelo direito de existir enquanto cidadãs nos marcos da justiça social, num Estado laico de direito (DINIZ, 2007). Isso revela um entendimento da realidade que grita existir um débito social histórico a ser resgatado às pessoas com deficiência no mundo.

\subsection{O Modelo Médico de Deficiência}

A narrativa biomédica foi a primeira guinada para a garantia dos direitos às pessoas com deficiência no século XIX. Antes uma expressão do azar ou do pecado, os impedimentos físicos, sensoriais ou cognitivos da pessoa com deficiência passaram a ser explicados com base na embriologia e na genética, e surgiram soluções nos campos da cirurgia ou da reabilitação (HUGUES apud BARBOSA et. al, 2009).

O modelo médico de Deficiência é um conjunto de ideias expostas pelos profissionais de saúde, particularmente pelos médicos, que há três séculos se ocuparam em estabelecer uma classificação de enfermidades (DINIZ, 2007), um forte discurso sobre o indivíduo, uma reflexão reduzida numa comparação a partir de um padrão corporal de normalidade (FOUCAULT, 1994).

O corpo com impedimentos tornou-se alvo do poder biomédico, cujo principal objetivo era normalizá-lo. A cultura da normalidade ganhou fôlego com os saberes biomédicos, que, ao explicarem a deficiência em termos científicos, apresentavam alternativas para a sobrevivência em uma regra de exclusão a bens e serviços pela diferença (BARBOSA et. al, 2009).

Este modelo está embasado por estudos e investigações sobre a etimologia da palavra patologia que é a manifestação no corpo e no organismo dos sujeitos, mediando concepção linear que ocorre em si mesmo na ideia do encadeamento entre a causa e os efeitos, com uma perspectiva determinista e permanente.

Os indivíduos que experimentavam a deficiência eram considerados anormais e necessitavam exclusivamente de acompanhamentos médicos para correções de suas lesões. A deficiência é detectada por uma mensuração de um padrão de normalidade, é um prejuízo social resultante de um azar individual.

No entanto, não há como descrever um corpo com deficiência como anormal. A 
anormalidade é um julgamento estético e, portanto, um valor moral sobre os estilos de vida conforme alerta Diniz (2007).

Discordar no entendimento da deficiência como algo anormal não significa ignorar que um corpo com lesão necessite de cuidados médicos ou de reabilitação. É inegável que os avanços biomédicos proporcionaram melhoria na qualidade de vida das pessoas com e sem deficiência. Afirmar a deficiência como um estilo de vida não é resultado exclusivo do progresso médico, é uma afirmação ética que desafia nossos padrões de normal e patológico.

No modelo médico, a deficiência é um problema da pessoa, consequência de qualquer problema de saúde que necessita de cuidados médicos. Esses cuidados visam à cura, à adaptação do indivíduo ou à alteração do seu comportamento. Os cuidados médicos são suficientes, apenas se considera o fator biológico na amplitude existente no fenômeno da deficiência. É esse o modelo que tem se consolidado no campo das ciências naturais (GUEDES et. al, 2006).

Foram as ciências médicas que criaram termos e conceitos que apontam as doenças e lesões de forma restrita, excluindo a subjetividade humana. Esse pensamento ignora as questões culturais, sociais e psicológicas que escapam ao biológico.

Tanto a diferenciação quanto a objetivação da lesão são práticas das ciências médicas (MEDEIROS et. al, 2006). Um exemplo dessa objetividade médica é a publicação, em 1980, da Classificação Internacional de Deficiências, Incapacidades e Desvantagens (CIDID) pela Organização Mundial de Saúde (OMS) (DINIZ, 2007; CHAGAS, 2006), um manual de classificação das enfermidades.

A CIDID codificou as doenças e lesões para sistematizar a linguagem biomédica baseando-se no modelo médico de deficiência, baseou-se em três principais conceitos que descreviam em uma sequência linear as condições decorrentes da lesão: lesão-deficiênciahandicap (DINIZ, 2007).

\footnotetext{
Lesão: é qualquer perda ou anormalidade psicológica, fisiológica ou anatômica de estrutura ou função;

Deficiência: é qualquer restrição ou falta resultante de uma lesão na habilidade de executar uma atividade de maneira ou da forma considerada normal para os seres humanos;

Handicap: é a desvantagem individual, resultante de uma lesão ou deficiência, que limita ou dificulta o cumprimento do papel considerado normal (WHO, 1980).
}

No manual, há uma relação de dependência entre esses três termos, uma vinculação à ideia de doença. O modelo médico coloca a deficiência como resultado de uma lesão no corpo de um indivíduo. Deficiência é sinônimo de lesão. A CIDID medicalizou a deficiência (WILLIAMS, 2001). No documento, tanto o conceito de handicap, como lesão e deficiência 
são considerados inadequados.

Os conceitos de lesão e deficiência na CIDID são embasados em estatísticas de normalidade, em curas de variação sobre os padrões dos corpos. Para a CIDID, lesão era uma condição necessária à deficiência, uma conexão que fundamentava a deficiência em termos exclusivamente biológicos: era a natureza quem determinava a desvantagem, e não os sistemas sociais e econômicos.

A CIDID ganhou força nos debates sobre a deficiência no mundo, houve uma valorização da autoridade do discurso médico com a devolução da deficiência ao campo das doenças ou consequências de doenças.

O modelo médico surgiu da necessidade de saber mais sobre as consequências das enfermidades, seria um manual de referência para as áreas médica, política e social. Muito embora tivesse essa pretensão, esse modelo é parcial e não conseguiu compreender a magnitude da deficiência em termos sociológicos, políticos e econômicos.

Para o modelo médico, a lesão leva a deficiência e pode gerar algumas condições de dependência, o que contribui para a personificação da pessoa com deficiência como incapaz no imaginário social coletivo. Parece que o modelo médico coloca em relevo a condição de dependência permanente, como se as pessoas com deficiência não pudessem ser autoras de seus próprios projetos de vida, representando um problema para a sociedade em que vivem.

É preciso debater o real significado implícito no modelo médico e os efeitos perversos que estão se assumindo no Estado e na sociedade. Nesse sentido, várias foram as publicações na intenção de denunciar a fragilidade da CIDID para o enfrentamento da questão política da deficiência. Oliver e Barnes (1998), então, apontam cinco críticas a CIDID: 1. o documento foi produzido por pessoas que não tinham experiência na deficiência, mas apenas sobre a deficiência, gerando uma fronteira ética importante; 2. a tipologia da CIDID baseava-se em pressuposições de normalidade, numa aproximação com fundamentos morais no debate sobre a deficiência; 3. existe um equívoco entre lesão e deficiência, numa imprecisão no sistema classificatório, o qual pressupunha que as desvantagens experimentadas pelas pessoas com deficiência resultavam exclusivamente das lesões; 4. a intervenção no corpo deficiente aproximava deficiência de doença, um corpo que precisava exclusivamente ser medicalizado; 5. a origem das desvantagens é na lesão, sendo apenas o corpo com lesão que necessitava de enfrentamento, numa análise individual e não sociológica, tendo implicações políticas na esfera da saúde pública.

A compreensão da deficiência pela CIDID era de uma limitação corporal resultante de uma tragédia particular que necessitava de medidas sanitárias de reabilitações (DINIZ, 2007). Essa compreensão da deficiência recebeu várias críticas dos estudiosos do modelo 
social de deficiência que propunham o entendimento da deficiência por aspectos sociais. Devido às diversas críticas, a OMS iniciou um processo de revisão da CIDID a partir da década de 1990 que resultou na publicação, em 2001, da CIF (DINIZ, 2007). Esse novo documento substituiu a ênfase negativa da deficiência por uma descrição neutra das estruturas corporais e seu funcionamento, considerando também a experiência da deficiência na realidade social (CHAGAS, 2006). Como queremos um debate da deficiência a partir da perspectiva da diversidade, nós devemos sim reconhecer as normatizações médicas e ir além, sendo preciso conhecer os fatores sociais, econômicos, políticos e culturais com os quais as pessoas com deficiência convivem.

\subsection{O Modelo Social de Deficiência}

O "modelo social da deficiência" é uma discussão sobre políticas de bem-estar e de justiça social para as pessoas com deficiência (BARBOSA et. al, 2009). A deficiência sai da exclusividade do discurso biomédico e entra para o campo das Ciências Humanas e Sociais a partir da década de 1970, por meio de um movimento de pessoas com deficiência que surge no Reino Unido, o que deu início ao "modelo social da deficiência". O eixo do debate sobre a deficiência foi modificado: o que antes era uma tragédia pessoal, passa a ser entendido como uma forma de opressão social (OLIVER e BARNES, 1998). Assim, segundo os teóricos do modelo social da deficiência, a deficiência deveria ser compreendida como consequência de estruturas sociais pouco sensíveis às diferenças corporais e não como um resultado de suas lesões (DINIZ, 2007; BARBOSA et. al, 2009).

Ocorreu uma transformação no conceito de deficiência a partir da Liga dos Lesados Físicos Contra a Segregação (Upias), a primeira organização de pessoas com deficiência a ser formada e gerenciada por pessoas com deficiência, foi um movimento político das pessoas com deficiência (MEDEIROS e DINIZ, 2004). A ideia de formar a organização foi do sociólogo Paul Hunt, que resolveu escrever uma carta ao jornal inglês The Guardian na intenção de criar um grupo de discussão sobre a deficiência:

\footnotetext{
Senhor editor, as pessoas com lesões físicas severas encontram-se isoladas em instituições sem as menores condições, onde suas idéias são ignoradas, onde estão sujeitas ao autoritarismo e, comumente, a cruéis regimes. Proponho a formação de um grupo de pessoas que leve ao parlamento as idéias das pessoas que, hoje, vivem nessas instituições e das que potencialmente irão substituí-las. Atenciosamente, Paul Hunt (DINIZ, 2007, p. 15).
}

Nesse primeiro momento, existia uma compreensão da deficiência a partir do conceito de estigma proposto por Goffman. O estigma é uma marca social que certos indivíduos carregam por possuírem características diversas daquelas padronizadas por uma 
sociedade. O autor diferencia três tipos de estima: 1 . as abominações do corpo; 2. as culpas de caráter individual; e 3. os estigmas de raça, nação e religião. O conceito de deficiência proposto pelo modelo social corresponderia ao primeiro tipo de estigma. O corpo com deficiência está à margem do padrão corporal estabelecido e, por não se adequar às normas sociais, é estigmatizado (GOFFMAN, 1988).

A Upias fundou o "modelo social de deficiência", rejeitou a deficiência como um problema individual, questionou a compreensão tradicional da deficiência, rompeu com o entendimento de deficiência como uma tragédia pessoal, apresentou a deficiência como uma questão eminentemente social. Nesse sentido, os objetivos da Upias eram

\begin{abstract}
diferenciar natureza de sociedade pelo argumento de que a opressão não era resultado da lesão, mas de ordenamentos sociais excludentes, na intenção de dessencializar a lesão, denunciando as construções sociológicas que a descreviam como desvantagem natural; e assumir a deficiência como uma questão sociológica, retirando-a do controle discursivo dos saberes biomédicos, isto é, o tema da deficiência não deveria ser matéria exclusiva dos saberes biomédicos, mas de ações políticas e de intervenção do Estado (DINIZ, 2007, p. 18).
\end{abstract}

Dois foram os argumentos que deram origem ao que hoje é conhecido como modelo social da deficiência. O primeiro é que o corpo ser lesado não determina e/ou explica o fenômeno social e político da subalternidade das pessoas com deficiência. Explicar a situação de opressão sofrida pelas pessoas com deficiência em termos das perdas de habilidades provocadas pela lesão é confundir lesão com deficiência. A deficiência é um fenômeno sociológico e lesão uma expressão da biologia humana. O significado da lesão como deficiência é um processo estritamente social. Houve uma retirada da deficiência do campo da natureza e sua transferência para a sociedade foi uma mudança revolucionária (ABBERLEY, 1987).

A deficiência é um fenômeno sociológico, por isso a solução para os conflitos envolvidos são da esfera política, não devendo se centrar na terapêutica. Isso é o central do segundo argumento. Os primeiros teóricos do modelo social definiam-se em oposição a todas as explicações individualizantes da deficiência, pois a deficiência não deveria ser entendida como um problema do indivíduo, uma trajetória pessoal, mas como uma consequência dos arranjos sociais pouco sensíveis à diversidade (ABBERLEY, 1987).

O marxismo foi a principal influência da primeira geração do modelo social da deficiência. A deficiência era resultado do ordenamento político e econômico capitalista, que delineava um tipo ideal de sujeito produtivo, era uma experiência vivenciada por pessoas com lesões devido a arranjos sociais opressivos (DINIZ, 2007).

Conforme análise de Diniz (2007), Paul Abberley foi um teórico da primeira geração que aproximou a compreensão da deficiência do fenômeno da opressão. A lesão não era um produto da natureza, mas uma consequência das relações de produção capitalistas. Era a 
divisão social do trabalho existente no capitalismo a responsável pelo aparecimento de lesões e da deficiência. O entendimento da lesão como algo natural era para o modelo social um entrave à consciência política das pessoas com deficiência.

O esforço do modelo social é informar que a deficiência não é um problema natural e individual, mas uma manifestação da "Questão Social", o que transfere a responsabilidade pelas desvantagens das limitações corporais do indivíduo para a incapacidade da sociedade em conviver com a diversidade humana (OLIVER, 1990). A deficiência deixa de ser um problema trágico de ocorrência isolada de alguns indivíduos para ser abordada como uma situação de discriminação coletiva e de opressão social para a qual a única resposta apropriada é a ação política (OLIVER e BARNES, 1998).

Para Diniz (2007), a diferenciação entre lesão e deficiência foi uma grande inovação trazida pelo modelo social da deficiência. O modelo social buscava diferenciar natureza e sociedade, separando a relação de causalidade entre lesão e deficiência, buscava definir deficiência como uma questão sociológica. Diferenciar lesão e deficiência contribuiria para uma compreensão de que uma pessoa pode experimentar a deficiência sem ter lesões, como pode ter alguma lesão e não experimentar a deficiência. A Upias assim redefiniu os conceitos:

\footnotetext{
Lesão é a ausência parcial ou total de um membro, ou membros, organismo ou mecanismo corporal defeituoso.

Deficiência é a desvantagem ou restrição de atividade provocada pela organização social contemporânea, que pouco ou nada considera aqueles que possuem lesões físicas e os exclui das principais atividades da vida social. A experiência da deficiência é entendida como uma desvantagem resultante da discriminação de sociedades pouco receptíveis a diversidade (DINIZ, 2007, p. 17).
}

A intenção era tornar os termos lesão e deficiência como distintos, o que contribui para transferir o debate para o campo da organização social e política. Lesão seria uma característica corporal e deficiência seria o resultado da opressão e da discriminação sofrida pelas pessoas em função de uma sociedade que se organiza de uma maneira que não permite incluí-las na vida cotidiana. Com a diferenciação dos conceitos, é possível uma pessoa ter lesão e não experimentar a deficiência, o que dependerá do quanto a sociedade esteja preparada para incorporar a diversidade (MEDEIROS e DINIZ, 2004). A partir dessa redefinição, os teóricos do modelo social propunham compreender deficiência "como uma experiência de opressão compartilhada por pessoas com diferentes tipos de lesões" (DINIZ, 2007, p. 22).

A crítica do modelo social não nasce para desqualificar a autoridade médica sobre os impedimentos corporais, mas para denunciar o aspecto opressor da medicalização dos corpos com impedimentos (DINIZ, 2007). Os defensores do modelo social concordavam que 
a lesão deveria ser alvo de cuidados biomédicos, objetivando uma melhor qualidade de vida, eles não recusavam os benefícios dos avanços biomédicos para o tratamento do corpo com lesões. A ideia era ir além da medicalização da lesão e atingir as políticas públicas para a deficiência.

A adoção do modelo social contribui para o entendimento de que as pesquisas e as políticas sociais direcionadas à deficiência não podem concentrar-se apenas nos aspectos corporais dos indivíduos para identificar a deficiência. Ao separar a deficiência da lesão, abre-se espaço para mostrar que, a despeito da diversidade de lesões, há um fator que une as diferentes comunidades de pessoas com deficiência em torno de um projeto político único à experiência da exclusão.

Oliver (1990) informa que as pessoas com deficiência experimentam a deficiência como uma restrição social, não importando se essas restrições ocorrem em consequência de ambientes inacessíveis, de noções questionáveis de inteligência e competência social, da inabilidade da população em geral para utilizar a linguagem de sinais, da falta de material em braile ou das atitudes públicas hostis das pessoas que não têm lesões corporais visíveis.

Já sabemos que os sistemas sociais opressivos levavam pessoas com lesões a experimentarem a deficiência. No entanto, era preciso deixar claro o quê o modelo social entendia por opressão pela deficiência. Nesse sentido, o objetivo de Abberley era duplo: diferenciar opressão de exploração e apresentar a lesão como uma consequência perversa do capitalismo.

"Os argumentos de Abberley tinham uma relação de causalidade: capitalismo-lesãodeficiência" (DINIZ, 2007, p. 24). Ele utilizou estatísticas de saúde que apresentava que 31\% dos casos mais severos de deficiência eram provocados por artrite. Diante da autoridade do argumento biomédico, o caso da artrite era fantástico. Assim, Abberley lançou os fundamentos do modelo social: 1. não se deve explicar o fenômeno da deficiência pela esfera natural ou individual, mas pelo contexto socioeconômico no qual as pessoas com lesão vivem; 2. é preciso estender os conceitos de lesão e deficiência a outros grupos sociais, como os idosos (DINIZ, 2007).

A proposta de Abberley foi uma teoria social da lesão, cujo fundamento era a estrutura do capitalismo, em especial o ordenamento social em torno do trabalho produtivo. Ele inclui, na categoria pessoas com deficiência, grupos não considerados como tal, como os idosos. A aproximação da deficiência ao envelhecimento foi um argumento estratégico adotado pelos teóricos do modelo social, na tentativa de ampliar a representação populacional, reconhecendo as demandas das pessoas com deficiência como demandas de justiça social (MEDEIROS e DINIZ, 2004).

Com toda essa discussão, foi construída uma teoria da deficiência como opressão 
pautada em cinco argumentos: 1. a ênfase nas origens sociais das lesões; 2. o reconhecimento das desvantagens sociais, econômicas, ambientas e psicológicas provocadas nas pessoas com lesões, bem como a resistência a tais desvantagens; 3. o reconhecimento de que a origem social da lesão e as desvantagens sofridas pelas pessoas com deficiência são produtos históricos e não resultado da natureza; 4. o reconhecimento do valor da vida das pessoas com deficiência, mas também a crítica à produção social das lesões; 5 . a adoção de uma perspectiva política capaz de garantir justiça às pessoas com deficiência.

A partir dos anos de 1990 as críticas feministas começaram a compor o debate sobre deficiência e configuraram a segunda geração de estudiosos do modelo social de deficiência (TOMAS e CORKER, 2004). Assim como as pessoas com deficiência eram oprimidas devido ao corpo com lesões, as mulheres eram oprimidas por causa do sexo e, dessa forma, as feministas encontraram na oposição à desigualdade uma aproximação argumentativa no debate sobre deficiência (DINIZ, 2007).

A afirmação de que os limites eram apenas sociais e não do indivíduo foi o ponto de partida das críticas feministas à primeira geração do modelo social de deficiência (THOMAS e CORKER, 2004; DINIZ, 2007). O objetivo foi ampliar o fenômeno da deficiência por meio da relação com outras variáveis de desigualdade, como raça, gênero, orientação sexual ou idade (THOMAS e CORKER, 2004). Foram as feministas que discutiram a necessidade de reconhecer os limites corporais, as dores e o sofrimento de determinadas lesões, pois era preciso reconhecer as particularidades do modo de vida da pessoa com deficiência, que é o corpo com lesão (DINIZ, 2007).

A deficiência, de acordo com o modelo social, é resultado de um processo histórico que incorporou as ideias e experiências dos movimentos sociais de pessoas com deficiência, as influências dos referenciais teóricos do materialismo histórico e das críticas feministas. O conceito de deficiência é complexo e está expresso na variedade de interpretações e experiências em torno do corpo e da relação deste com o ambiente (MEDEIROS et. al, 2006).

Em consequência das discussões acerca do modelo social das últimas décadas, a OMS lançou a CIF que apresenta o fenômeno da deficiência e da incapacidade tanto pela função e/ou estrutura do corpo quanto sua participação social. A funcionalidade e as incapacidades do indivíduo são determinadas pelo contexto ambiental e participação social onde a pessoa vive. A CIF representa uma nova maneira de se pensar a deficiência, é um instrumento importante para a avaliação das condições de vida e para a promoção de políticas de inclusão (FARIAS e BUCHALLA, 2005).

A funcionalidade é o principal termo no modelo da CIF, cobre os componentes de 
funções e estruturas do corpo, atividade e participação social, é utilizada em contraposição à incapacidade como aspecto negativo. A CIF informa que incapacidade é

\footnotetext{
resultante da interação entre a disfunção apresentada pelo indivíduo (seja orgânica e/ou da estrutura do corpo), a limitação de suas atividades e a restrição na participação social, além dos fatores ambientais que podem atuar como facilitadores ou como barreiras para o desempenho dessas atividades e da participação social (WHO, 2001).
}

A CIF é baseada numa abordagem biopsicossocial que incorpora os componentes de saúde nos níveis corporais e sociais, é dividida em cinco componentes que interagem entre si: as funções e estruturas do corpo, a atividade social, a participação social, os fatores ambientais e os fatores pessoais (WHO, 2001).

A utilização do modelo da CIF na saúde pública, segundo Farias e Buchalla (2005), pode fornecer as bases para políticas e disciplinas em relação à população com deficiência, pois o reconhecimento da contribuição do meio ambiente sobre as pessoas com deficiência, agindo como barreiras ou facilitadores no desempenho de suas atividades e na participação social, mudou o foco do problema da natureza biológica individual para a interação entre a disfunção apresentada e o contexto ambiental onde as pessoas estão inseridas.

Ainda hoje não há unicidade no que se entende por pessoa com deficiência (ALBRECHT; SEELMAN; BURY, 2001). No entanto, as últimas décadas revelaram o entendimento de que a deficiência não pode ser identificada apenas por atributos corporais dos indivíduos, devendo ser entendida como resultado da interação dos atributos corporais, atributos socioeconômicos e o meio em que vive a pessoa (DINIZ, 2007; BARNES; OLIVER; BARTON, 2002). Nesse sentido, é o modelo social da deficiência que representa um avanço no debate sobre a deficiência em nível mundial, evidencia a necessidade de problematizar a relação de um corpo com lesão com as estruturas sociais existentes, sendo necessária uma relação com a política, a economia, o social. Após essa discussão, é importante conhecer quem são as pessoas que sofrem a opressão pelo corpo no Brasil, saber sobre esse segmento populacional que por muitas décadas foram invisíveis na sociedade e que lutam por justiça, liberdade, equidade.

\subsection{O Fenômeno da Deficiência no Brasil}

A mais importante coleta de dados das pessoas com deficiência no Brasil é datada do ano 2000, último censo realizado pelo Instituto Brasileiro de Geografia e Estatística (IBGE). Antes desse censo, existiram formas distintas de coleta de dados e outras perspectivas sobre a deficiência.

As contagens populacionais de 1872 e de 1900 e o Censo Demográfico de 1920 
buscaram conhecer o contingente das pessoas com deficiência visual e auditiva no Brasil. Em 1872, existiam $0,16 \%$ de pessoas cegas e $0,12 \%$ de surdos. Em 1900, existiam 0,18\% de cegos e $0,07 \%$ de surdos. No censo de 1920 , esses números aumentaram para $0,30 \%$ de cegos e $0,26 \%$ de surdos, todos esse dados em relação à população total (NÉRI e SOARES, 2003).

O censo de 1940 foi um pouco além, buscou analisar a natureza da cegueira e da surdez, detectou em que idade a deficiência foi adquirida. Com esse estudo, percebeu-se que quanto maior a idade, maior é a possibilidade de se experimentar a deficiência.

Em 1981, a Pesquisa Nacional por Amostra de Domicilio (PNAD) abrangeu um universo maior das deficiências: cegueira, surdez, surdo-mudez, retardamento mental, falta de membro, paralisia total, paralisia de um dos lados do corpo, outros tipos de deficiências, mais de um tipo de deficiência. A PNAD/1981 concluiu que cerca de 1,78\% da população brasileira tinha alguma deficiência. Já o Censo de 1991 utilizou o mesmo universo de deficiências da pesquisa de 1981 e o resultado foi que $1,15 \%$ da população brasileira tinha alguma deficiência (NÉRI e SOARES, 2003).

O Censo de 2000 utilizou uma nova metodologia, incluindo pessoas com alguma incapacidade de ouvir e enxergar, bem como limitações físicas e mentais em níveis diferenciados. O Censo revelou que $14,5 \%$ da população brasileira apresentavam algum tipo de deficiência, o que correspondia a 24,5 milhões de pessoas (IBGE, 2000). Esse grande aumento estatístico não se referiu a um aumento do número de pessoas com deficiência no Brasil. A grande diferença percentual foi por conta da mudança nos mecanismos de coleta de dados que passou a considerar não apenas lesões graves, mas as dificuldades física, motora, visual, sensitiva e mental em diferentes dimensões. A tabela 1 revela os resultados do Censo/2000 sobre a representação percentual em relação às lesões.

Tabela 1 - Percentual da população total com alguma lesão pelo Censo 2000

\begin{tabular}{l|r}
\hline \multicolumn{1}{c|}{ LESÃO } & \multicolumn{1}{c}{$\%$} \\
\hline Dificuldade de enxergar & 53,2 \\
\hline Dificuldade de caminhar & 15,7 \\
\hline Dificuldade de ouvir & 13,8 \\
\hline Deficiência mental & 9 \\
\hline Tetraplegia,falta de um membro ou parte dele & 4,3 \\
\hline Dificuldade permanente de caminhar & 2,3 \\
\hline Dificuldade permanente de ouvir & 0,7 \\
\hline Dificuldade permanente de enxergar & 0,6 \\
\hline Paraplegia ou hemiplegia & 0,4 \\
\hline Fonte: IBGE, 2000. &
\end{tabular}


O Censo de 2000 revelou que as dificuldades de enxergar, de caminhar e de ouvir representam $82,7 \%$ das lesões sofridas pelas pessoas com deficiência. Sob a perspectiva de gênero, houve uma contagem de 13,1 milhões de mulheres com deficiência e 11,4 milhões de homens com deficiência, representados percentualmente no gráfico 1. As lesões mais freqüentes entre as mulheres foram a dificuldade permanente de enxergar e de caminhar (IBGE, 2000; CHAGAS, 2006).

Gráfico 1 - Representação percentual de pessoas com deficiência de acordo com o gênero/sexo

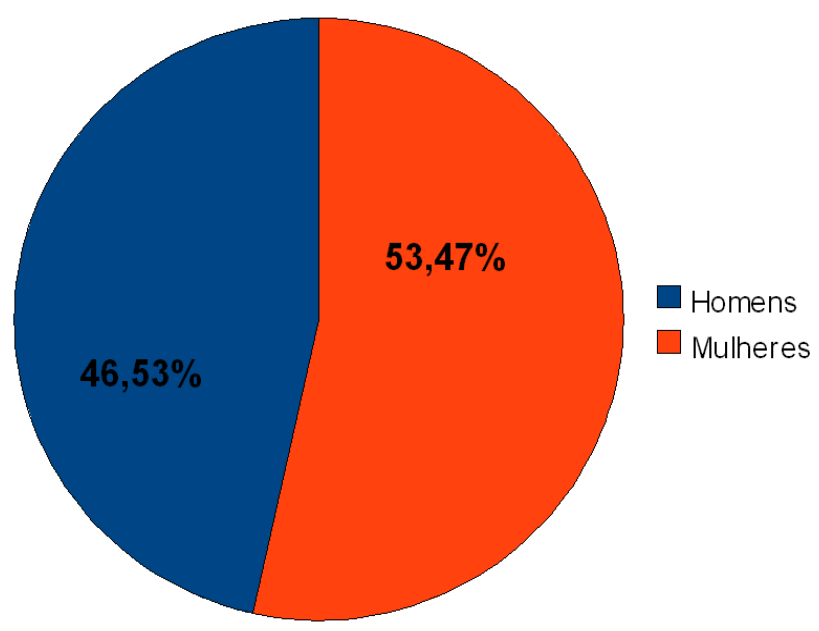

Fonte: IBGE, 2000.

Segundo o Censo 2000, as pessoas com deficiência divididas por gênero/sexo apontam uma ligeira predominância das mulheres. Do segmento de mulheres que possuem algum tipo de deficiência, $46 \%$ não têm acesso a terapias e um terço é analfabeta ou somam, no máximo, três anos de escolaridade.

Squinca (2006) informa que não é possível fazer uma análise das pessoas com deficiência a partir de uma concepção homogênea, como se todos fossem iguais e tivessem as mesmas necessidades, pois, assim, seria negada a existência de uma diversidade corporal. Como exemplo, entre as pessoas com deficiência do sexo feminino, a relação de subalternização é acirrada, existe a aglutinação entre duas categorias que sofrem discriminação no capitalismo - pessoa com deficiência e mulher.

O Censo 2000, ao quantificar a porcentagem de pessoas com deficiência com o recorte de idade, ilustrados no gráfico 2 , revela-se que a porcentagem da população com algum tipo de deficiência aumenta com a avanço da idade. A maior porcentagem fica entre as pessoas com 50 anos ou mais, marcando $42,5 \%$ e a menor porcentagem é de $4,67 \%$ entre as pessoas com 0 a 17 anos. 
Gráfico 2 - Representação percentual das pessoas com deficiência com recorte de idade

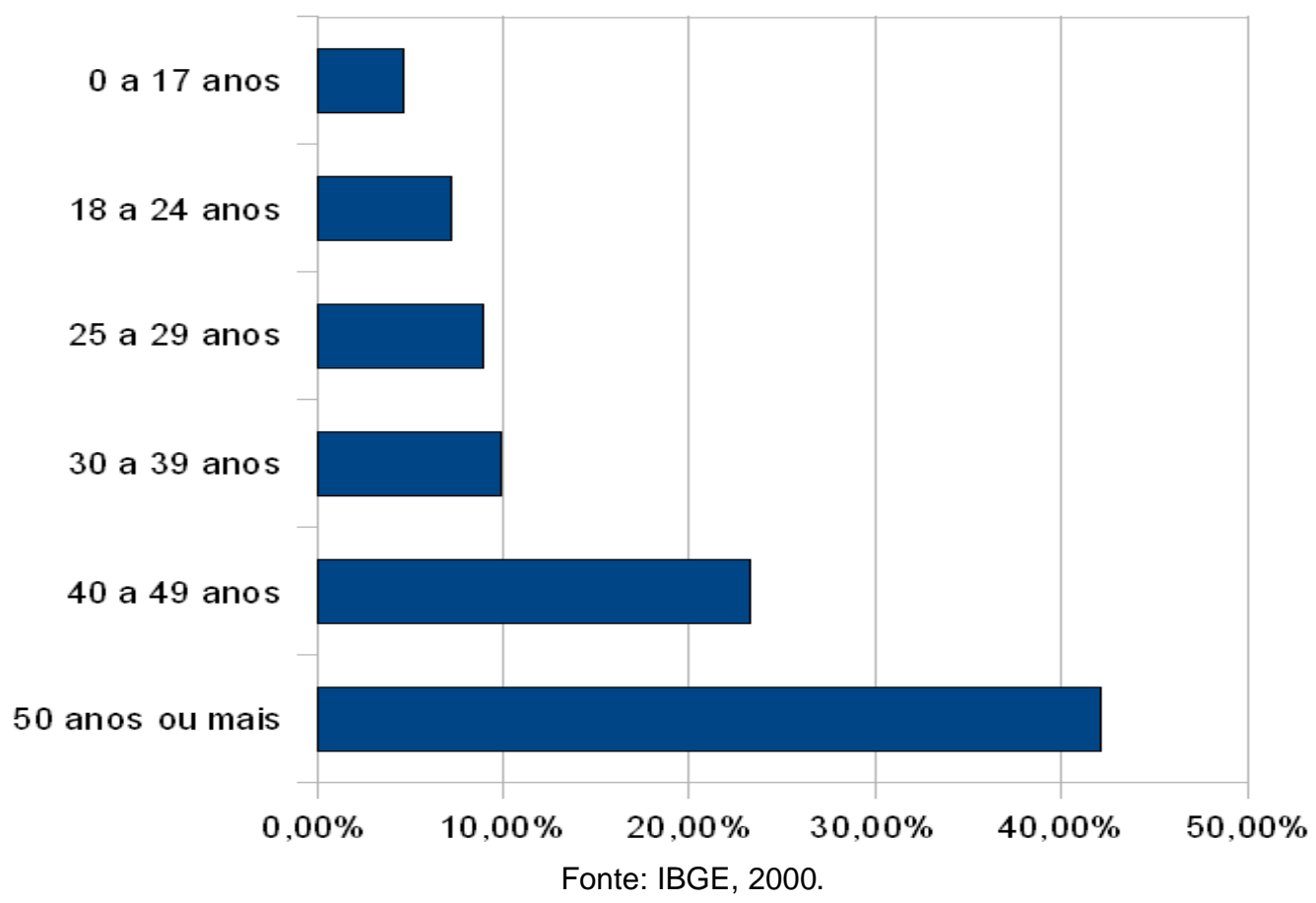

O Censo 2000 está de acordo com o entendimento de Medeiros e Diniz (2004) sobre a relação entre deficiência e envelhecimento. Esses autores defendem um conceito de deficiência para além de um problema individual, fruto de tragédia pessoal e colocam o debate da deficiência para a esfera social e política, uma responsabilidade de todos, principalmente porque vivemos num modo de produção que explora, exclui e discrimina. $\mathrm{O}$ processo de envelhecimento, conforme já anunciado, é um exemplo paradigmático da deficiência. A deficiência não é uma experiência limitada a uma minoria reduzida, mas um fato ordinário e previsível no curso de vida das pessoas, assim como o envelhecimento. Os autores mostram que a relação entre envelhecimento e deficiência é importante por várias razões:

1. o envelhecimento vem acompanhado de algumas limitações nas capacidades físicas e, às vezes, intelectuais mas, apesar do envelhecimento crescente de quase todas as populações do mundo, na maioria delas pouco ou nada se tem feito para que essas limitações não se tornem causa de deficiências; 2. na ausência de mudanças na forma como as sociedades organizam seu cotidiano, todos seguem em direção a uma fase da vida em que se tornarão pessoas com deficiência, o que motiva, ainda que por meio da defesa de interesses egoístas, a melhoria das políticas públicas voltadas à deficiência; 3 . a interdependência e o cuidado não são algo necessário apenas diante de situações excepcionais e sim necessidades ordinárias em vários momentos da vida de todas as pessoas; 4 . a previsibilidade do envelhecimento permite entender que muito da deficiência é resultado de um contexto social e econômico que se reproduz no tempo, pois a deficiência no envelhecimento é, em parte, a expressão de desigualdades surgidas no passado e que são mantidas (MEDEIROS e DINIZ, 2004, p. 18). 
O Censo 2000 também observou a distribuição por cor das pessoas com deficiência. A distribuição foi classificada de acordo com as nomenclaturas utilizadas pelo IBGE e revelou a seguinte relação entre deficiência e raça/etnia.

Gráfico 3 - Pessoas com deficiência por raça/etnia

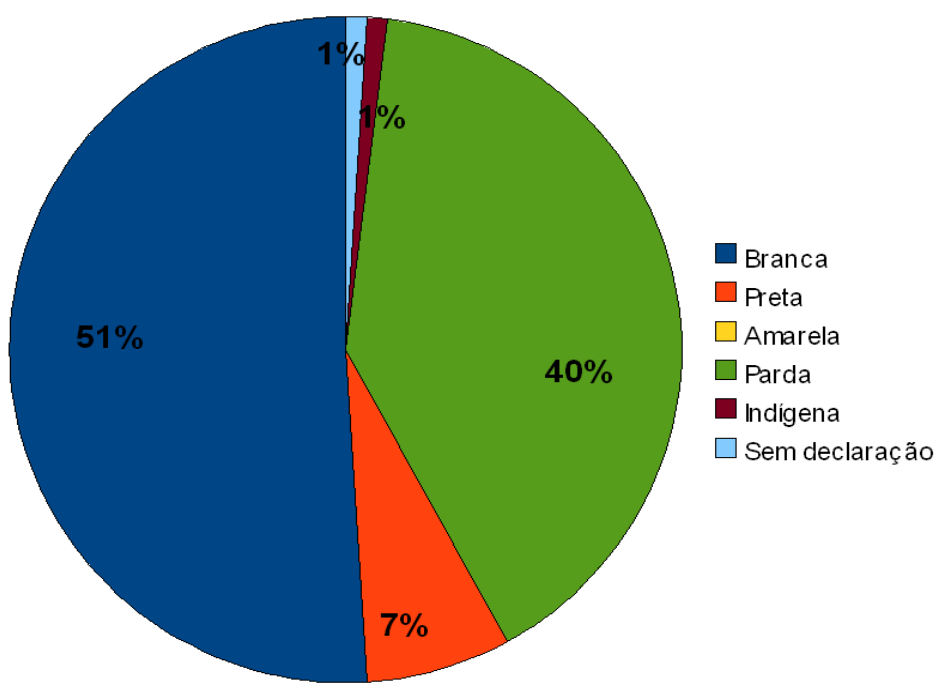

Fonte: IBGE, 2000.

Em relação ao aspecto da Educação, o Censo 2000 observou que a taxa de alfabetização das pessoas que não tinham deficiência com 15 anos ou mais de idade foi de $87 \%$. A taxa de $72 \%$ foi a observada entre as pessoas com deficiência (IBGE, 2000). Um dado alarmante na relação pessoa com deficiência e escola é apontado pelo Censo 2000: apenas $13 \%$ das pessoas com deficiência frequentavam a escola contra $34,7 \%$ de pessoas que não tinham alguma deficiência com frequência escolar (CHAGAS, 2006). Nesse sentido, é possível confirmar a desvantagem social das pessoas com deficiência na escola. A educação é um direito social de todos, no entanto, de acordo com o Censo 2000, é um direito que ainda é um desafio quanto à universalidade, um direito que não atende às demandas das pessoas com deficiência.

A relação do trabalho com a deficiência também foi analisada pelo Censo 2000. A participação das pessoas com deficiência no mercado de trabalho alcançou um índice de $38,6 \%$, enquanto esse dado era expresso em $50 \%$ na situação das pessoas que não possuíam deficiência (CHAGAS, 2006; IBGE, 2000). A questão do desemprego é um problema da conjuntura política e econômica no Brasil, o que contribui para uma exclusão de milhões de pessoas do trabalho e o não atendimento dos direitos da seguridade social.

Como um reflexo da questão do trabalho, a renda também é um problema no Brasil, onde, de acordo com o Censo $2000,44,5 \%$ da população de pessoas que não possuem deficiência não recebem rendimentos, taxa superior a de $31 \%$ das pessoas com deficiência 
(CHAGAS, 2006; IBGE, 2000). Chagas (2006) aponta que o motivo dessa prevalência dos rendimentos das pessoas com deficiência deve-se ao BPC e à Renda Mensal Vitalícia (RMV), recebidos por 1,5 milhão de pessoas com deficiência em 2006. Assim, 32\% das pessoas com deficiência recebem até um salário mínimo de rendimento, enquanto $15 \%$ das pessoas que não possuem deficiência recebem esse mesmo rendimento, porém, em relação às pessoas que recebem acima de cinco salários mínimos, 9,4\% são pessoas com deficiência e 11,6\% são pessoas que não possuem deficiência (CHAGAS, 2006).

Um dos grandes desafios da relação trabalho e deficiência, apontado no Censo 2000, foi a dificuldade das pessoas com deficiência mental no ingresso no mercado de trabalho. Segundo o Censo, 19\% das pessoas com deficiência mental permanente estão inseridas no mercado de trabalho e, em relação às outras deficiências, temos os seguintes percentuais de inclusão no mercado trabalho: $41 \%$ das pessoas com dificuldade para enxergar, $34 \%$ das pessoas com dificuldade de audição, $25 \%$ das pessoas com alguma incapacidade física ou motora (IBGE, 2000; CHAGAS, 2006; NÉRI et. al, 2003).

Assim, com os dados apresentados, é possível concluir que existe uma relação de desigualdade das pessoas com deficiência em relação às pessoas que não possuem deficiência no Brasil. As pessoas com deficiência experimentam a exclusão no acesso a diversas esferas da vida social: no trabalho, na educação, na renda, na acessibilidade. Possuem os seus direitos básicos dificultados, e muitas vezes não atendidos, para além das dificuldades das pessoas que não possuem deficiência porque ainda são várias as barreiras impostas pela sociedade no próprio direito das pessoas com deficiência de estarem no mundo. No entanto, é possível perceber um ligeiro avanço na perspectiva de "inclusão" na vida social da deficiência como algo inerente à sociedade e na busca por igualdade, mesmo que seja apenas a de oportunidade, por meio de algumas legislações de direito ao trabalho, à acessibilidade, à educação, à renda. O BPC é um exemplo paradigmático do avanço na relação deficiência e renda, é um benefício da política de assistência social, é um direito para algumas pessoas que experimentam a deficiência no Brasil que iremos problematizar no próximo capítulo. 


\section{CAPÍTULO 2}

\section{A TRAJETÓRIA DO BPC NO BRASIL}

\subsection{O Benefício de Prestação Continuada}

A organização social do trabalho é o eixo estruturante da seguridade social que é constituída de forma diferenciada em cada país, em decorrência de questões estruturais, como o grau de desenvolvimento do capitalismo e de questões conjunturais, como a organização da classe trabalhadora. A seguridade social brasileira, instituída na CF/1988, incorporou princípios tanto da lógica do contrato (ou do seguro) do modelo alemão do Chanceler Otto Von Bismarck quanto da lógica social do modelo inglês de William Beveridge porque restringe a previdência social aos trabalhadores contribuintes, a saúde é universal e limita a assistência social a quem dela necessitar. Esse mix em torno da seguridade social no Brasil, que fica entre o seguro e a assistência, em um contexto de severa desigualdade social, pobreza estrutural e fortes relações informais de trabalho, deixa sem acesso aos direitos da seguridade social uma grande parcela da população (BOSCHETTI, 2006; 2009).

O BPC é parte da política de assistência social no Brasil, constitui transferência direta de renda, independente de contribuição, o que aproxima a assistência social da garantia de um padrão básico de atendimento de necessidades, de um direito incondicional. Indica a direção de seu caráter universalizante (GOMES, 2008).

Historicamente, conforme Gomes (2008), as ações de assistência social para a população idosa e pessoas com deficiência eram sinônimo de programas descontínuos, incertos e desarticulados, marcados por características assistencialistas. Com o BPC, iniciou-se um padrão de assistência social como certeza e regularidade, rompeu-se com o tradicional campo de ações da assistência social em que predominava a ausência de regras claras e definidas para acesso, dependente da disponibilidade financeira.

A partir do BPC ocorreu a primeira proteção social de massa na política de assistência social, pois:

a) quebrou a tradicional regulação ad hoc, aquela operada caso a caso pelo ajuizamento individual de técnicos sociais a partir de critérios pouco objetivos com concessão no âmbito interno de uma instituição; b) introduziu a forma pública de relação social do Estado no acesso a benefícios não contributivos no campo da assistência social; c) afiançou a condição de certeza de acesso à atenção de idosos e de pessoas com deficiência (SPOSATI, 2008, p. 125). 
O BPC é um benefício em nível federal cuja operacionalização fica a cargo do INSS, sob a coordenação do MDS. O benefício foi previsto na CF/1988 que estabeleceu o seguinte:

Art. 203. A assistência social será prestada a quem dela necessitar, independente de contribuição à seguridade social, e tem por objetivos:

V - a garantia de um salário mínimo de benefício mensal à pessoa portadora de deficiência e ao idoso que comprovem não possuir meios de prover à própria manutenção ou de tê-la provida por sua família, conforme dispuser a lei (BRASIL, 1988).

Após cinco anos de debates sobre a regulamentação da política de assistência social, foi promulgada a LOAS/1993, uma lei que regulamentou os artigos 203 e 204 da CF/1988 e dispõe sobre a organização da Assistência Social.

Foi a LOAS/1993 que apresentou os elementos constitutivos do BPC. Apesar de instituído pela CF/1988 e regulamentado pela LOAS/1993, a implantação do BPC se deu apenas em 1996 - oito anos após a sua inserção na CF/1988 e três anos após essa lei.

O BPC substituiu a RMV que era uma espécie de "braço assistencial" da previdência e contribuiu para certa redução da pobreza absoluta dos idosos, pessoas com deficiência e doentes crônicos. Segundo Gomes (1999), a inserção do BPC na CF/1988 realizou um avanço em relação à RMV: com o BPC, não há exigência de quaisquer contribuições.

No entanto, com a substituição da RMV pelo BPC, constatam-se alguns problemas: 1. a solução de continuidade, pois os novos acessos à RMV foram interrompidos sem que fosse iniciada a concessão do BPC; 2. o menor alcance e abrangência do BPC em relação à RMV, uma vez que o primeiro possui critérios mais restritivos de acesso (GOMES, 2001).

Quando regulamentado pela LOAS/1993, o BPC teve seu alcance reduzido se compararmos com a RMV: 1. inicialmente, a idade para acesso do idoso foi estipulada em 70 anos na LOAS/1993 e não em 65 anos conforme RMV; 2. houve uma restrição no entendimento sobre deficiência: a RMV ia além da pessoa com deficiência incapacitada para o trabalho e vida independente, alcançava pessoas com patologias crônicas (GOMES, 2008).

Após novas leis e decretos, o BPC, então, é reconhecido atualmente como o primeiro benefício não contributivo garantido na $\mathrm{CF} / 1988$, é uma transferência de renda para idosos com 65 anos ou mais ou pessoas com deficiência incapacitadas para a vida independente e para o trabalho que comprovem não possuir meios para prover a própria manutenção e nem de tê-la provida por sua família, o que representa uma comprovação de renda familiar per capita inferior a um quarto de salário mínimo ( $\mathrm{R} \$ 127,50 \mathrm{em}$ agosto de 2010). O valor do benefício é igual a um salário mínimo mensal ( $R \$ 510,00$ em agosto de 2010). As transferências não são vitalícias, são intransferíveis, independentes de contribuições prévias 
para o sistema de seguridade social e não podem ser acumuladas a outros benefícios da seguridade social com exceção da assistência médica e da pensão especial de natureza indenizatória. É um benefício integrado às demais políticas setoriais, visa ao enfrentamento da pobreza, à garantia da proteção social, ao provimento de condições para atender contingências sociais e à universalização dos direitos sociais (BRASIL, 1993; 2007a; 2007d; 2008).

Entretanto, na análise de Gomes (2001), o BPC é bastante seletivo e focalizado naqueles absolutamente incapazes de prover sua subsistência, os quais estão em situação de vulnerabilidade social praticamente irreversível, considerando inclusive a renda per capita exigida de um quarto de salário mínimo. Desse ponto de vista, o BPC se separou da característica universalizante da assistência social.

BPC e renda per capita, a partir da LOAS/1993, passam a ser elementos indissociáveis. Pereira (1998) afirma que a focalização revela o BPC como um direito arbitrário, restrito, dependente de verificação de cumprimento dos critérios para acesso, de um atestado de necessidade, o que contribui para a estigmatização dos beneficiários como necessitados. O rigoroso critério de elegibilidade associado à inexistência de articulação com outros programas e serviços, acaba por privilegiar o seu caráter emergencial, constituindo-se numa "armadilha da pobreza" e, perversamente, reforço das desigualdades sociais (PEREIRA, 1998).

Os parágrafos relativos ao art. 20 da LOAS/1993 procuram regulamentar mais detalhadamente os critérios para acesso ao BPC:

§ 1ํ Para os efeitos do disposto no caput, entende-se como família o conjunto de pessoas elencadas no art. 16 da Lei n. 8.213, de 24 de julho de 1991, desde que vivam sob o mesmo teto. (nova redação dada pela Lei $n^{0} .9 .720 / 98$ ).

$\S 2^{\circ}$ Para efeito de concessão deste benefício, a pessoa portadora de deficiência é aquela incapacitada para a vida independente e para o trabalho.

$\S 3^{\circ}$ - Considera-se incapaz de prover a manutenção da pessoa portadora de deficiência ou idosa a família cuja renda mensal per capita seja inferior a 1/4 (um quarto) do salário mínimo.

$\S 4^{\circ} \mathrm{O}$ benefício de que trata este artigo não pode ser acumulado pelo beneficiário com qualquer outro no âmbito da seguridade social ou de outro regime, salvo o da assistência média.

$\S 5^{\circ}$ A situação de internado não prejudica o direito do Idoso ou do portador de deficiência ao benefício.

$\S$ 6ำ A concessão do benefício ficará sujeita a exame médico pericial e laudo realizados pelos serviços de perícia médica do Instituto Nacional do Seguro Social INSS. (nova redação dada pela Lei $n^{0}$. 9.720/98).

$\S 7^{0} \mathrm{Na}$ hipótese de não existirem serviços no município de residência do beneficiário, fica assegurado, na forma prevista em regulamento, o seu encaminhamento ao município mais próximo que contar com tal estrutura. (nova redação dada pela Lei $n^{0}$.9.720/98).

$\S 8^{\circ}$ A renda familiar mensal a que se refere $\circ \S 3^{\circ}$ deverá ser declarada pelo 
requerente ou seu representante legal, sujeitando-se aos demais procedimentos previstos no regulamento para o deferimento do pedido. (nova redação dada pela Lei $n^{0}$. 9.720/98) (BRASIL, 1993).

Esses parágrafos apresentam uma série de elementos definidores dos termos conceituais e dos parâmetros estabelecidos pela LOAS/1993 e que servem de base para a sua operacionalização.

O BPC deverá ser requerido junto às agências da previdência social ou aos órgãos autorizados para este fim (BRASIL, 2007a). Os formulários utilizados para o requerimento do benefício serão disponibilizados pelo MDS, INSS, órgãos autorizados e em meios eletrônicos oficiais.

Para fins de identificação da pessoa com deficiência e do idoso e de comprovação da idade do idoso, deverá o requerente apresentar um dos seguintes documentos: 1. certidão de nascimento; 2. certidão de casamento; 3. certificado de reservista; 4. carteira de identidade; ou 5. carteira de trabalho e previdência social (BRASIL, 2007a).

A comprovação da renda familiar mensal per capita será feita mediante "Declaração da Composição e Renda Familiar" em formulário próprio, assinado pelo requerente ou seu representante legal, confrontado com os documentos pertinentes, ficando o declarante sujeito às penas previstas em lei no caso de omissão de informação ou declaração falsa (BRASIL, 2007a).

Os rendimentos dos componentes da família do requerente deverão ser comprovados mediante a apresentação de um dos seguintes documentos: 1. carteira de trabalho e previdência social com as devidas atualizações; 2 . contracheque de pagamento ou documento expedido pelo empregador; 3. o Guia da Previdência Social - GPS no caso de Contribuinte Individual; ou 4. extrato de pagamento de benefício ou declaração fornecida por outro regime de previdência social público ou previdência social privada (BRASIL, 2007a).

A evolução nos números de idosos e pessoas com deficiência atendidos até maio de 2010 são bastante expressivos. Segundo o MDS, o BPC foi destinado a 346.219 idosos e pessoas com deficiência em 1996, no seu ano de implantação. Em maio de 2010, o número de beneficiários aumentou aproximadamente 842\% em comparação a todo o ano de 1996, sendo destinado a mais de 3,2 milhões pessoas no Brasil. 
Quadro 1 - Evolução da quantidade de beneficiários do BPC no Brasil (1996-2010*)

\begin{tabular}{|c|c|c|c|c|c|}
\hline Ano & PcD & $\% \mathrm{PcD}$ & Idosos & $\%$ Idosos & Total \\
\hline 1996 & 304.227 & 87,87 & 41.992 & 12,13 & 346.219 \\
\hline 1997 & 557.088 & 86,25 & 88.806 & 13,75 & 645.894 \\
\hline 1998 & 641.268 & 75,59 & 207.031 & 24,41 & 848.299 \\
\hline 1999 & 720.274 & 69,76 & 312.299 & 30,24 & 1.032 .573 \\
\hline 2000 & 806.720 & 66,68 & 403.207 & 33,32 & 1.209 .927 \\
\hline 2001 & 870.072 & 64,97 & 469.047 & 35,03 & 1.339 .119 \\
\hline 2002 & 976.257 & 62,55 & 584.597 & 37,45 & 1.560 .854 \\
\hline 2003 & 1.036 .365 & 60,92 & 664.875 & 39,08 & 1.701 .240 \\
\hline 2004 & 1.127 .849 & 54,72 & 933.164 & 45,28 & 2.061 .013 \\
\hline 2005 & 1.211 .761 & 53,21 & 1.065 .604 & 46,79 & 2.277 .365 \\
\hline 2006 & 1.293 .645 & 52,22 & 1.183 .840 & 47,78 & 2.477 .485 \\
\hline 2007 & 1.385 .107 & 51,67 & 1.295 .716 & 48,33 & 2.680 .823 \\
\hline 2008 & 1.510 .682 & 51,48 & 1.423 .790 & 48,52 & 2.934 .472 \\
\hline 2009 & 1.563 .970 & 51,17 & 1.492 .302 & 48,83 & 3.056 .272 \\
\hline $2010^{*}$ & 1.688 .881 & 51,78 & 1.572 .743 & 48,22 & 3.261 .624 \\
\hline
\end{tabular}

O quadro 1, que revela a evolução dos benefícios por categoria de usuário (idosos e pessoas com deficiência), demonstra o desenvolvimento de uma proporção diferenciada ao longo dos anos. No ano em que a operacionalização do benefício foi iniciada, os idosos representavam apenas $12,13 \%$ do total de beneficiários, enquanto as pessoas com deficiência representavam $87,87 \%$. Os dados mais recentes evidenciam uma proporcionalidade diferente, uma vez que os idosos representam aproximadamente $48,22 \%$ do total dos beneficiários e as pessoas com deficiência representam aproximadamente $51,78 \%$. As pessoas com deficiência ainda expressam a maior parte dos beneficiários atendidos pelo BPC, no entanto podemos observar um crescimento significativo dos idosos atendidos pelo programa.

Um componente que deve ser destacado para o aumento dos beneficiários idosos foi a redução da idade limite: passou-se dos 70 anos no texto inicial da LOAS/1993 para 67 anos consequência da Lei $n^{0} .9 .720$ de 1998 e para 65 anos a partir do Estatuto do Idoso de outubro de 2003.

O aumento do número de idosos também está de acordo com o próprio processo de envelhecimento populacional no Brasil. Os dados estatísticos do IBGE apontam o crescimento quantitativo da população idosa no Brasil ao longo dos anos. O último censo revelou um quantitativo de, aproximadamente, 10 milhões de pessoas com 65 anos ou mais no Brasil (IBGE, 2000). Todavia, a constatação de que mais de 1,5 milhão de idosos acessaram o BPC em maio 2010 tende a indicar a grave situação de vulnerabilidade social desse 
segmento populacional.

O FNAS, como apontam Boschetti et. al (2006), vem apresentando crescimento ao longo dos anos: 1,3 bi de reais (1996), 1,7 bi de reais (1997), 2,1 bi de reais (1998), 2,9 bi de reais (1999), 3,7 bi de reais (2000), 4,8 bi de reais (2001), 5,7 bi de reais (2002), 8,1 bi de reais (2003). Em 2009, o fundo contou com, aproximadamente, 19,2 bilhões de reais destinados para a Proteção Social Básica e Especial. Desse montante, um investimento de, aproximadamente, 16,9 bilhões de reais foi utilizado para o pagamento do BPC, um valor, aproximadamente, 9.782\% superior ao valor necessário para o pagamento do benefício em 1996 (quadro 2).

Quadro 2 - Evolução do investimento com o BPC no Brasil (1996-2010*) (em R\$)

\begin{tabular}{|l|r|r|r|}
\hline \multicolumn{1}{|c|}{ Ano } & \multicolumn{1}{c|}{ PcD } & \multicolumn{1}{c|}{ Idosos } & \multicolumn{1}{c|}{ Total } \\
\hline 1996 & 148.282 .853 & 24.060 .088 & 172.342 .940 \\
\hline 1997 & 674.961 .409 & 94.771 .269 & 769.732 .678 \\
\hline 1998 & 912.771 .073 & 221.428 .227 & 1.134 .199 .299 \\
\hline 1999 & 1.107 .283 .715 & 425.838 .708 & 1.533 .122 .422 \\
\hline 2000 & 1.360 .524 .997 & 640.943 .222 & 2.001 .468 .219 \\
\hline 2001 & 1.767 .144 .248 & 926.877 .264 & 2.694 .021 .512 \\
\hline 2002 & 2.176 .399 .854 & 1.251 .700 .370 & 3.428 .100 .225 \\
\hline 2003 & 2.790 .381 .784 & 1.742 .839 .724 & 4.533 .221 .508 \\
\hline 2004 & 3.300 .027 .494 & 2.514 .255 .524 & 5.814 .283 .018 \\
\hline 2005 & 4.054 .094 .729 & 3.469 .766 .715 & 7.523 .861 .444 \\
\hline 2006 & 5.112 .542 .025 & 4.606 .245 .556 & 9.718 .787 .581 \\
\hline 2007 & 5.987 .030 .235 & 5.561 .314 .689 & 11.548 .344 .925 \\
\hline 2008 & 7.110 .730 .320 & 6.675 .058 .372 & 13.785 .788 .691 \\
\hline 2009 & 8.638 .336 .138 & 8.221 .076 .468 & 16.859 .412 .606 \\
\hline $2010^{*}$ & 4.227 .816 .610 & 3.970 .546 .638 & 8.198 .363 .245 \\
\hline
\end{tabular}

Fonte: http://www.mds.gov.br/relcrys/bpc/download_beneficiarios_bpc.htm *Dados até maio/2010

O financiamento da assistência social é orientado a partir da CF/1988 no art. 195 pelo princípio da co-responsabilidade entre governos federal, estadual e municipal e suas fontes se originam tanto do orçamento da seguridade social como do orçamento fiscal. Estudos acerca do financiamento da assistência social revelam que duas importantes tendências têm marcado o comportamento dos recursos do FNAS.

A primeira é o crescimento constante dos recursos, que passaram de $0,68 \%$ do orçamento da seguridade social, em 1996, ano de sua regulamentação, 1,28\% (1997), 1,56\% (1998), 1,77\% (1999), 2,03\% (2000), 2,24\% (2001), para 2,5\% (2002), 2,7\% (2003) e 3,48\% (2004) (BOSCHETTI et. al, 2006). A segunda tendência é de crescente concentração desses recursos no BPC que foi responsável por 79,5\% dos recursos do FNAS em 2003, 92\% (2004), 89,15\% (2005) (BOSCHETTI e SALVADOR, 2006) e de 88,5\% em 2009. 
Gráfico 4 - Representação percentual dos gastos do FNAS em 2009

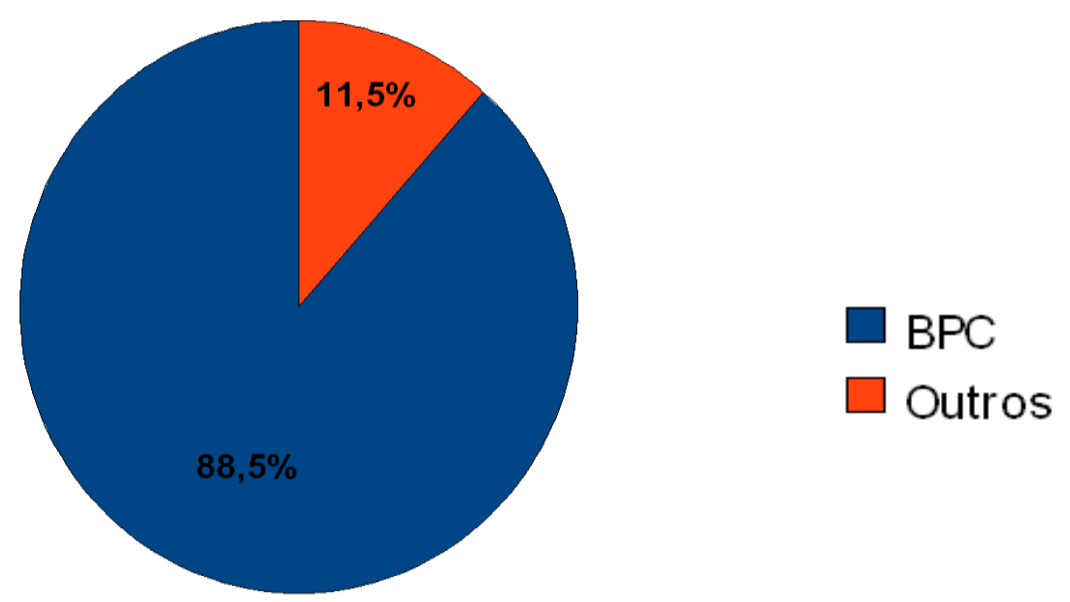

Fonte: http://www9.senado.gov.br/portal/page/portal/orcamento_senado/_LOA/Elaboracao:PL?p_ano=2009

Esses dados indicam a importância do BPC dentro da política pública de assistência social, uma magnitude dada não só pelo montante dos recursos utilizados, mas pela expressiva quantidade de usuários que o acessam.

Ao tomar conhecimento dos números do acesso ao BPC, podemos indicar informações relevantes sobre os usuários que são atendidos pelo programa. Esses dados expõem em parte as condições sociais pelas quais passam os idosos e as pessoas com deficiência em situações de pobreza no Brasil. São milhões de pessoas que estão excluídas do mercado formal de trabalho e, portanto, não tiveram acesso aos direitos previdenciários, que procuram uma forma de sobreviver por meio de um benefício que contribui para a redução da pobreza absoluta no Brasil (GOMES, 2008). Junto com o Programa Bolsa Família, o BPC foi uma das soluções para minorar os efeitos do não acesso aos direitos da seguridade social no Brasil, principalmente porque não alcançamos o patamar europeu de sociedade salarial, sendo, portanto, uma estratégia de compensação de ausência de rendimentos do trabalho (BOSCHETTI, 2006; 2008).

Após conhecermos alguns elementos do BPC e por esse trabalho se tratar dos desafios da avaliação social para acesso ao BPC, uma atividade ligada à operacionalização do benefício, o próximo item abordará como foi toda a trajetória operacional para saber como esse direito está sendo implementado. 


\subsection{A operacionalização do BPC}

O BPC, como já foi exposto, consiste em um programa que garante um salário mínimo mensal aos idosos e às pessoas com deficiência no Brasil que não tenham condições de manter a sua sobrevivência e que estejam comportados dentro de determinados critérios como o de idade mínima (no caso dos idosos), renda per capita inferior a $1 \frac{1}{4}$ de salário e deficiência que incapacite o sujeito para a vida independente e para o trabalho (BRASIL, 1993; 2007a).

O Decreto $n^{0}$. 1.330, de 8 de dezembro de 1994, foi o primeiro instrumento que estabeleceu as regras iniciais para a operacionalização do BPC. O Decreto previa o início da operacionalização do benefício para junho de 1995 com a consequente manutenção, no âmbito da previdência social, do pagamento da RMV (BRASIL, 1994).

Entretanto, o benefício teve seu início protelado para janeiro de 1996. Um mês antes, foi assinado um novo Decreto, o de $n^{0} .1 .744$, de 8 de dezembro de 1995, que redefinia a data de início da operacionalização do BPC, assim como estabelecia a responsabilidade e a competência de organizar e implementar os meios necessários à consecução da operacionalidade do programa para o INSS, assim:

Art. 43. Compete ao Instituto Nacional de Seguro Social (INSS) expedir as instruções e instituir formulários e modelos de documentos necessários à operacionalização do benefício de prestação continuada previsto neste Regulamento (BRASIL, 1995).

O decreto 1.744/1995, então, definiu os conceitos e os procedimentos que serviram de modelo adotado pelo INSS para a organização de todo o instrumental necessário (instruções normativas, formulários, etc.) à efetiva operacionalização do benefício.

Muito embora o BPC seja de origem da política de assistência social, foram apresentadas duas justificativas para a escolha do INSS na sua operacionalização: 1. a presença do órgão em grande parte dos municípios brasileiros; 2. a experiência acumulada com a organização e o controle dos benefícios previdenciários que possuíam abrangência nacional.

Durante o período de preparação para o início da operacionalização do BPC, diversos comunicados foram expedidos e procuravam:

mobilizar os gerentes e chefes de postos para verificação de todas as medidas necessárias e preconizadas para a implantação do benefício a partir do $1^{\circ}$ dia útil do ano, em especial, aquelas que possibilitam a orientação adequada a idosos e deficientes que acorrerem aos nossos Postos, a partir da madrugada de $3^{\underline{a}}$ feira, dia 02/01/96 (INSS, 1995, p. 8). 
Iniciado o ano de 1996, várias foram as dúvidas que surgiam de diferentes municípios, o que gerou a necessidade de confecção do instrumento denominado de "Nota Técnica" (INSS, 1996) que compreendia um conjunto de perguntas e respostas sobre os procedimentos operacionais do benefício.

Nos primeiros anos de implantação do BPC, os procedimentos para o acesso sofreram alterações com relação aos critérios e às sistemáticas para a inclusão do beneficiário. Em síntese, podemos identificar quatro períodos diferentes que expressavam características particulares quanto aos critérios de acesso ao benefício.

1. por meio do Decreto 1.744/1995, quando se inicia a concessão, em 1996 , constatam-se exigências e interpretações que extrapolam a LOAS/1993, de par com as resoluções e ordens de serviço do INSS. Esse período vai de janeiro de 1996 a agosto de 1997, com a ressalva de que já em março de 1997, pela resolução INSS no. 435 , os laudos e os pareceres emitidos pelas demais instituições ficam submetidos à avaliação da perícia do Instituto Nacional de Seguridade Social INSS, sem a presença do beneficiário; 2 . com a previsão do novo conceito de família pela Medida Provisória n‥ 1.473/34, somente a perícia do INSS compete a emissão de laudos e pareceres, e delega ao próprio beneficiário a responsabilidade pela declaração de renda - período a partir de setembro de 1997; 3. a partir de 1998, ocorreu a sistemática para revisão e avaliação dos beneficiários para fins de manutenção ou cancelamento do benefício (GOMES, 2001, p.117);

4. a Ordem Interna de Serviço do INSS/DIRBEN (Diretoria de Benefícios) / n‥ 081, de 15 de janeiro de 2003, que dispôs sobre os novos elementos para o roteiro de procedimentos para operacionalização do benefício de prestação continuada, destinado a idosos e pessoas portadoras de deficiência (INSS, 2003, p. 1).

Esses momentos expressam um conjunto de particularidades e procedimentos específicos, no entanto todos têm o mesmo objetivo: estabelecer os critérios e os conceitos adotados para a operacionalidade do BPC, os paradigmas adotados pelas equipes responsáveis pela concessão e/ou revisão do benefício.

O texto inicial da LOAS/1993 estabeleceu alguns itens que deveriam compor os procedimentos operacionais do benefício, como: 1. a compreensão a respeito do conceito de família; 2. a idade mínima para o idoso; 3. a definição de pessoa com deficiência; 4. o patamar financeiro per capita; 5 . a proibição do acúmulo do BPC com outro benefício da seguridade social exceto assistência médica; 5. a necessidade do laudo pericial expedido por uma equipe multiprofissional que ateste a deficiência (BRASIL, 1993).

A LOAS/1993 procurou regulamentar os parâmetros que deveriam ser adotados na organização dos procedimentos operativos do benefício. Alguns autores apontam que os parâmetros de acesso foram muito restritivos, no entanto não podemos deixar de considerar que a lei é produto de correlações de forças políticas em uma dada conjuntura histórica que, no caso, está intimamente associada ao contexto de "contrarreforma" do Estado brasileiro que gerou mudanças sociais e políticas importantes após o período de redemocratização do país (BEHRING, 2003). 
Após alguns anos de debate sobre os elementos colocados pelo Decreto 1.744/95, principalmente nos requisitos de acesso ao BPC, foram editados dois novos Decretos que promoveram algumas melhorias no sentido de se aproximar de um modelo de benefício com maior justiça social. Dentre essas melhorias, destacamos: um novo instrumento de avaliação da pessoa com deficiência, facilidade do acosso de pessoas em situação de rua, avanço no cálculo da renda familiar per capita para o caso dos idosos, a acumulação do BPC com outros benefícios no âmbito da seguridade social.

Atualmente, existem dois Decretos que regulamentam o BPC. O decreto $n^{0}$. 6.214, de 26 de setembro de 2007, que revogou os Decretos $n^{0}$. 1.744/1995 e $n^{0}$. 4.712/2003. No Decreto de 2007, podemos apontar importantes avanços em relação aos seguintes pontos:

1. Estabeleceu-se que o desenvolvimento das capacidades cognitivas, motoras ou educacionais e a realização de atividades não remuneradas de habilitação e reabilitação, dentre outras, não constituem motivo de suspensão ou cessação do benefício e possibilita novo acesso do benefício à pessoa com deficiência que teve o BPC cessado para assumir trabalho remunerado;

2. Instituição de novo modelo para avaliação da deficiência e do grau de incapacidade para fins de acesso ao BPC, composta por uma avaliação médica e outra social, que obedecerá aos critérios da CIF, o que permitiu analisar não apenas as limitações na estrutura e funções do corpo, mas também o impacto de fatores ambientais e sociais na limitação do desempenho de atividades e na restrição de participação social;

3. Instituição do Sistema Nacional de Monitoramento e Avaliação do BPC que permitirá o registro do acompanhamento dos beneficiários e suas respectivas famílias no âmbito do SUAS e do seu acesso a outras políticas e abarcará a revisão periódica de que trata 0 art. 21 da LOAS/1993;

4. Mudança da concepção de família para o cálculo da renda per capita: conjunto de pessoas que vivem sob o mesmo teto, assim entendido, o requerente, o cônjuge, a companheira, o companheiro, o filho não emancipado, de qualquer condição, menor de 21 anos ou inválido, os pais, e o irmão não emancipado, de qualquer condição, menor de 21 anos ou inválido;

5. Quando o requerente for pessoa em situação de rua, deve ser adotado como referência o endereço do serviço da rede socioassistencial pelo qual esteja sendo acompanhado, ou, na falta deste, de pessoas com as quais mantém relação de proximidade;

6. As famílias das pessoas em situação de rua são as elencadas no tópico 4 , desde que convivam com o requerente na mesma situação de rua; 
7. O BPC será devido a mais de um membro da mesma família enquanto atendidos os requisitos de elegibilidade, no entanto o BPC concedido a idoso não será computado no cálculo da renda mensal bruta familiar.

Já o Decreto $\mathrm{n}^{0}$. 6.564, de 12 de setembro de 2008, alterou o regulamento do BPC, aprovado pelo Decreto de 2007, e aprovou as seguintes alterações:

1. O BPC poderá ser acumulado apenas com dois outros benefícios no âmbito da seguridade social: a assistência médica e a pensão especial de natureza indenizatória;

2. No ato do requerimento do BPC, não é obrigatório apresentar o Cadastro de Pessoa Física (CPF);

3. Para fins de reconhecimento do direito ao BPC às crianças e adolescentes menores de 16 anos de idade, deve ser avaliada a existência da deficiência e o seu impacto na limitação do desempenho de atividade e restrição da participação social, compatível com a idade, sendo dispensável proceder à avaliação da incapacidade para o trabalho;

4. Também é beneficiário do BPC o brasileiro naturalizado, domiciliado no Brasil, idoso ou com deficiência, observados os critérios estabelecidos, que não perceba qualquer outro benefício no âmbito da seguridade social ou de outro regime, nacional ou estrangeiro, salvo o da assistência médica e no caso de recebimento de pensão especial de natureza indenizatória;

5. O MDS e o INSS tiveram o prazo até o dia 31 de maio de 2009 para implementar a avaliação da deficiência e do grau de incapacidade.

Os decretos de 2007 e de 2008 possuem grande relevância para este trabalho, uma vez que se constituem nos instrumentos reguladores do benefício hoje. A partir desses Decretos, o INSS precisou organizar todos os procedimentos internos, com os correspondentes instrumentais técnicos para a efetividade do BPC. Cabe considerar que

\footnotetext{
o decreto tem como função regulamentar a Lei, criando os procedimentos para a sua efetiva operacionalização, não podendo, assim, extrapolar aos limites desta ou criar obrigações, condições, restrições ou direitos não previstos pela Lei ou artigo que objetiva regulamentar (CFESS, 1996, p. 4).
}

Partindo desse entendimento, pretendemos analisar neste TCC, principalmente, a questão da obrigatoriedade da avaliação social a partir de 31 de maio de 2009, prazo estipulado pelo Decreto de 2008 para a introdução desse novo instrumento que promoverá acesso às pessoas com deficiência ao BPC. Parte essencial da avaliação social é conhecer um pouco da história de acesso ao BPC pelas pessoas com deficiência. Nesse sentido, vamos problematizar no próximo item a relação do BPC com a pessoa com deficiência no Brasil. 


\subsection{BPC e Pessoa com Deficiência}

Tanto a LOAS/1993 quanto o Decreto 6.214/2007 afirmam que "pessoa com deficiência é aquela cuja deficiência a incapacita para a vida independente e para o trabalho", mediante avaliação da deficiência e do grau de incapacidade que será composta de avaliação médica e social (BRASIL, 1993; 2007a).

Compreender o que vem a ser essa condição de incapacitado é bastante problemática, principalmente a incapacidade para 0 trabalho, pois os procedimentos técnicos adotados para o reconhecimento desta incapacidade referem-se ao enquadramento do usuário em certos requisitos delimitados pelo INSS.

Até maio de 2009, o INSS utilizava uma tabela que avaliava se as pessoas com deficiência eram consideradas aptas ao BPC. Era uma avaliação exclusivamente feita pelos médicos-perito do INSS. O "Acróstico Avaliemos" foi o instrumento utilizado para enquadrar as pessoas com deficiência à condição de incapacitado para a vida independente e para o trabalho. Esse instrumento seguia uma lógica a partir de pontuação em uma tabela, sendo o laudo uma conclusão resumida e foi utilizado como modelo em todas as agências do INSS espalhadas pelo Brasil, independentemente das particularidades regionais (GOMES, 2008).

Entretanto, desconsiderou-se a realidade heterogênea dos estados e municípios brasileiros, diferenças marcantes entre regiões e entre as áreas urbanas e rurais. Nesse sentido, o "Acróstico Avaliemos" tendeu a uma operacionalização do BPC discriminatória e injusta, já que um município que possui uma economia mais desenvolvida acaba contando com uma oportunidade maior de acesso ao trabalho para as pessoas com deficiência.

O "Acróstico Avaliemos" colidia com a diretriz da descentralização políticoadministrativa da LOAS/1993 e também com o princípio da igualdade no acesso ao atendimento, sem discriminação de qualquer natureza, garantindo-se equivalência às populações urbanas e rurais. Assim, a igualdade de direitos ao acesso implica em construir as condições necessárias para os futuros beneficiários da assistência social tanto na zona rural quanto urbana, o que remete à importância de organizar os critérios de elegibilidade de forma descentralizada política e administrativamente e priorizar as características e particularidades locais na implantação de ações do benefício.

Um grande problema do BPC para pessoas com deficiência encontra-se na imprecisão conceitual sobre a deficiência. Parece existir um consenso do entendimento de que a deficiência não pode ser identificada apenas por atributos corporais dos indivíduos, conforme a perspectiva do velho "Acróstico Avaliemos", devendo ser entendida como resultado da interação dos atributos corporais, atributos socioeconômicos e o meio em que vive a pessoa (DINIZ, 2007). O BPC está em consonância com esse debate: o Decreto 
6.214/2007 determina que a definição de incapacidade leve em conta a interação entre a pessoa e seu ambiente físico e social (MEDEIROS et. al, 2009).

Para endossar o problema anterior, a incapacidade para o trabalho não é objeto do debate teórico sobre deficiência e BPC. A discussão sobre o BPC parece concentrar nos critérios de renda utilizados pelo programa (COSTA, 2009). Segundo estudos, os próprios peritos encarregados da seleção de beneficiários do BPC não utilizam critérios uniformes para definir incapacidade para o trabalho (BARBOSA et. al, 2009; DINIZ et. al, 2007).

Não encontramos princípios constitucionais que contribuam no entendimento de incapacidade como incapacidade absoluta, o que parece caracterizar a elegibilidade da pessoa com deficiência ao BPC. Entendemos incapacidade para o trabalho como incapacidade de conseguir um trabalho cuja remuneração seja suficiente para assegurar a própria subsistência (MEDEIROS et. al, 2009).

O BPC, benefício componente da política de seguridade social, constitui como o principal da política de assistência social para as pessoas pobres com deficiência, pois garante proteção às necessidades básicas (MEDEIROS et. al, 2009). No entanto, a imprecisão conceitual sobre quem seja a pessoa com deficiência contribui para a restrição no acesso ao benefício.

O modelo médico de deficiência foi hegemônico para orientar a perícia médica para o acesso ao BPC: a dificuldade estava em como estabelecer as fronteiras entre deficiências e doenças crônicas. No entanto, a demonstração do limite do modelo biomédico para avaliar os processos de exclusão ao benefício provocados pela deficiência contribuiu para questionar a exclusividade dos saberes biomédicos para avaliar se uma pessoa com deficiência tem direito ao BPC (BARBOSA et. al, 2009).

Os critérios que visam a compreensão de quem seja a pessoa com deficiência foram alterados no Brasil em 2009 por meio da adoção da CIF, o que modificou os critérios de elegibilidade ao BPC. Passa-se a avaliar a deficiência com base na participação de uma pessoa com impedimentos corporais na vida social, o que aproxima o conceito do modelo social de deficiência, resultado da relação entre um corpo com impedimentos e a sociedade. Entende-se que o ambiente impõe restrições e barreiras à plena participação (BARBOSA et. al, 2009).

Além da incorporação da CIF nos critérios de acesso ao BPC, o Congresso Nacional ratificou a Convenção sobre os Direitos das Pessoas com Deficiência, um novo instrumento legal que contribui para uma nova era para as políticas sociais relativas à deficiência (BRASIL, 2009). A Convenção apresenta o novo conceito de deficiência que vai além do corpo com impedimentos, reconhece na restrição de participação um fenômeno determinante para a identificação da pessoa com deficiência, conforme defendido pela CIF. 
A Convenção reconstrói o conceito de deficiência, sendo a referência para identificar quem é a pessoa com deficiência que terá direito ao BPC.

Muito embora tenhamos uma evolução no conceito de deficiência, existe uma disputa do modelo médico e social de deficiência no momento da perícia médica. Pesquisas revelam que afirmar o modelo biomédico como o único presente na perícia médica do BPC é uma interpretação errada. O que existe é uma tensão entre os modelos biomédico e social da deficiência na prática da perícia médica. Como exemplo, pesquisa realizada em Brasília no II Congresso Brasileiro de Perícia Médica Previdenciária em 2009, que contou com a participação de 850 médicos-perito, chegou-se a conclusão de que há casos em que o modelo biomédico no processo da perícia médica é questionado. A tensão entre os dois modelos pode ser identificada na pergunta sobre uma criança de três anos com anemia falciforme e crises regulares de dor. Essa pergunta feita aos médicos buscou saber se o caso seria elegível ao BPC. Como resposta, 38,2\% (171) dos peritos responderam que não e 59,2\% (265) disseram que sim (BARBOSA et. al, 2009). A anemia falciforme é uma doença genética que causa alterações nas hemoglobinas, prejudicando o transporte de oxigênio pelo corpo e causando problemas circulatórios de várias ordens (SILVA; RAMALHO; CASSORLA, 1993). A anemia falciforme não é tradicionalmente considerada deficiência para o modelo biomédico, podendo gerar severas restrições de participação ou ser amplamente controlada por meio de cuidados diários (GUIMARÃES; MIRANDA; TAVARES, 2009). Segundo o modelo biomédico, a doença talvez não fosse considerada deficiência, no entanto a maioria dos peritos respondeu que o caso era elegível ao BPC.

A subjetividade dos médicos na avaliação também é outro problema que podemos apontar na antiga avaliação da deficiência e do grau de incapacidade: uma mesma situação era avaliada de forma diferente, o que contribuía para o não acesso ao benéfico de milhares de pessoas com deficiência no Brasil.

Os intensos debates sobre a questão do acesso ao BPC para pessoas com deficiência fez surgir a necessidade de ir além da avaliação médica, foi reconhecida a necessidade imperiosa de se adotar tanto a perícia médica, que sempre ocorreu desde o início do BPC, quanto a avaliação social, realizada pelo Serviço Social do INSS, entendendo que o fenômeno da deficiência vai além do aspecto médico, devendo ser considerados os aspectos sociais na avaliação para saber se uma pessoa com deficiência é elegível ao benefício. Nesse sentido, em 2009, a avaliação social se tornou o mais novo instrumento para acesso ao BPC para mais de 1,6 milhão de pessoas com deficiência no Brasil. É sobre esse novo instrumento que trataremos no próximo item deste capítulo. 


\subsection{BPC, Deficiência e Avaliação Social}

A Lei $n^{0}$. 8.662/1993, que dispõe sobre a profissão de assistente social, afirma ser uma competência do assistente social "realizar estudos sócio-econômicos com os usuários para fins de benefícios e serviços sociais junto a órgãos da administração pública direta e indireta, empresas privadas e outras entidades" e ser uma atribuição privativa "realizar vistorias, perícias técnicas, laudos periciais, informações e pareceres sobre a matéria de Serviço Social" (BRASIL, 1993).

A perícia pode ser considerada como um processo por meio do qual um especialista realiza o exame de situações sociais com a finalidade de emitir um parecer sobre a mesma. Quando solicitada a um profissional de Serviço Social, é chamada de perícia social, que é um estudo social, realizado com base nos fundamentos teórico-metodológicos, éticopolíticos e técnico-operativos próprios do Serviço Social (MIOTO, 2001). A perícia social diz respeito a

uma avaliação, exame ou vistoria, solicitada ou determinada sempre que a situação exigir um parecer técnico ou científico de uma determinada área do conhecimento, que contribua para o juiz formara a sua convicção para a tomada de decisão (FÁVERO, 2008, p. 43).

O trabalho do assistente social no âmbito do INSS exige diferentes competências e atribuições. Nesse estudo, iremos analisar a função do assistente social como perito social, responsável em realizar a avaliação social para analisar, após o requerimento da pessoa com deficiência, se a sua deficiência é elegível ou não ao BPC.

A realização da avaliação social estabelecida pelo Decreto de 2007 representa um avanço no reconhecimento inicial do direito ao BPC destinado às pessoas com deficiência. No novo modelo, o fenômeno da incapacidade passa a ser entendido também como resultante da maneira como a sociedade se organiza. Partindo desse entendimento, "a incapacidade passa a ser não mais apreendida como um atributo da pessoa, mas como consequência de um conjunto complexo de situações, das quais um número razoável é criado pelo próprio contexto sócio-ambiental" (BRASIL, 2007d, p. 42)

Diferentes dimensões da saúde (biológica, individual e social), ao serem apreendidas e consideradas na avaliação social e médica, permitem uma visão de totalidade, entendendo o fenômeno da incapacidade para a vida independente e para o trabalho nos seus múltiplos aspectos. Com o intuito de reduzir o grau de limitação e subjetividade existente nos moldes anteriores de avaliação da pessoa com deficiência, esse novo modelo busca uma uniformização na construção dos instrumentos de avaliação e inseriu a perspectiva de totalidade prevista na avaliação social. 
Essa compreensão está fundamentada na CIF que utiliza a terminologia "incapacidade" para conceituar um fenômeno multidimensional que resulta da interação entre pessoas e seu ambiente físico e social, não se tratando, porém, de uma classificação de pessoas, mas das características de saúde das mesmas dentro do contexto das situações individuais de vida e dos impactos ambientais (BRASIL, 2007d).

A trajetória da avaliação social é muito recente no BPC. Em maio de 2009, Patrus Ananias, então Ministro de Estado do MDS, e Valdir Moysés Simão, Presidente do INSS, assinaram a Portaria Conjunta MDS/INSS $n^{0}$. 1, de 29 de maio de 2009, que instituiu instrumentos para avaliação da deficiência e do grau de incapacidade de pessoas com deficiência requerentes ao BPC (BRASIL, 2009), tendo por base: 1. o novo modelo de avaliação social que amplia a mera avaliação da deficiência e do grau de incapacidade da pessoa com deficiência requerente ao BPC; 2 . o estabelecimento da data de 31 de maio de 2009 para início da avaliação social para efeito da revisão e concessão do BPC (decreto $\mathrm{n}^{0}$. 6.564/2008); e 3. a determinação legal acerca da responsabilidade de operacionalização do BPC pelo INSS.

Os instrumentos são constituídos de dois modelos diferentes, assim discriminados:

a) avaliação da deficiência e do grau de incapacidade - Pessoa com deficiência - 16 anos ou mais;

b) avaliação da deficiência e do grau de incapacidade - Pessoa com deficiência criança e adolescente menor de 16 anos (BRASIL, 2009b, Art. 1‥ $§ 1^{\circ}$.).

Cada modelo do instrumento para avaliação da deficiência e do grau de incapacidade é constituído por duas partes distintas, sendo que os campos destinados à utilização pelo assistente social do INSS possuem algumas particularidades, principalmente nos elementos a serem avaliados considerando os grupos etários, da seguinte forma:

I - Assistente Social:

a) avaliação social, considerando e qualificando os fatores ambientais por meio dos domínios: produtos e tecnologias; condições de moradia e mudanças ambientais; apoios e relacionamentos; atitudes; serviços, sistemas e políticas.

b) avaliação social considerando e qualificando atividades e participação - parte social, para requerentes com 16 anos de idade ou mais, por meio dos domínios: vida doméstica; relação e interações interpessoais; áreas principais da vida; vida comunitária, social e cívica.

c) avaliação social, considerando e qualificando atividades e participação - parte social, para requerentes menores de 16 anos de idade, por meio dos domínios: relação e interações interpessoais; áreas principais da vida; vida comunitária, social e cívica (BRASIL, 2009b, Art. 2º, I).

A avaliação social destina-se a avaliar os fatores ambientais, sociais e pessoais da pessoa com deficiência, considerando a limitação do desempenho de atividades e a 
restrição da participação social, segundo suas especificidades. Essa nova forma de analisar a deficiência está fundamentada na CIF que orienta uma avaliação que leve em consideração a interação entre pessoas e seu ambiente físico e social, não se tratando, porém, de uma classificação de pessoas, mas das características de saúde das mesmas dentro do contexto das situações individuais de vida e dos impactos ambientais (BRASIL, 2007d).

O processo da avaliação social para acesso ao BPC consiste num instrumento técnico-operacional que tem a finalidade de realizar o estudo e emitir a opinião profissional sobre o grau de barreiras existente em relação aos fatores contextuais, ou seja, as condições pessoais e do ambiente físico e social onde vive o indivíduo e o grau das dificuldades existentes em relação à atividade e participação (BRASIL, 2007d). Nesse sentido, a avaliação social objetiva avaliar o grau de deficiência e incapacidade e as dificuldades vivenciadas pelas pessoas numa sociedade pouco tolerante à diversidade corporal.

A avaliação social é realizada após o requerimento de pessoas com deficiência ao BPC nas agências da previdência social do INSS, prioritariamente nessas agências ou, quando necessário, em domicílios, instituições hospitalares e em outros locais. É o assistente social, pertencente ao quadro próprio de pessoal do INSS, regularmente inscrito no Conselho Regional de Serviço Social (CRESS), o responsável em realizar a avaliação social.

Quanto aos princípios que norteiam a avaliação social, são postas exigências contemporâneas para o assistente social que passam por três dimensões: conhecimento teórico-metodológico, compromisso ético-político e capacitação técnico-operativa. Essas dimensões remetem aos princípios elencados no Código de Ética do Assistente Social, de 1993, e na Lei de Regulamentação da Profissão, de 1993 (GUERRA, 1995).

São componentes da avaliação social os fatores ambientais e a atividade e participação. Fatores ambientais são constituídos pelo ambiente físico e social no qual as pessoas vivem e conduzem suas vidas. Esses fatores são externos ao indivíduo e formam o contexto da vida, podendo influenciar de forma positiva (facilitador) ou negativa (barreira) na capacidade de desempenhar ações na participação em sociedade ou sobre a função ou estrutura do corpo (BRASIL, 2007d).

Atividade e Participação, o segundo componente da avaliação social, consiste na execução de uma tarefa ou ação por um indivíduo e seu envolvimento em uma situação da vida. A atividade representa a perspectiva individual da funcionalidade e a participação a perspectiva social da funcionalidade (BRASIL, 2007d).

No processo de avaliação social, há elementos importantes para saber o que e quais 
são os domínios da avaliação social com base na CIF. Avaliam-se os conjuntos práticos e significativos de ações, tarefas ou áreas da vida. Cada componente da avaliação social contém vários domínios que são organizados em nível individual ou social (BRASIL, 2007d).

Em relação ao nível individual, é avaliado o ambiente imediato do indivíduo como: domicílio, local de trabalho e escola. Inclui as características físicas e materiais do ambiente em que o indivíduo se encontra, bem como o seu relacionamento com a família, conhecidos, vizinhos, e outros. Já em relação ao nível social, são avaliadas as estruturas sociais formais e informais, regras de conduta, sistemas predominantes na comunidade ou sociedade que têm impacto sobre a vida do indivíduo: aqui inclui a existência de organizações, atividades comunitárias, órgãos governamentais, serviços de comunicação e de transporte e redes sociais, bem como leis, regulamentações, regras formais e informais (BRASIL, 2007d).

Os domínios do componente Fatores Ambientais são: 1. produtos e tecnologia; 2. condições de moradia e mudanças ambientais; 3 . apoio e relacionamentos; 4 . atitudes; 5. serviços, sistemas e políticas.

Quadro 3 - Domínios que são avaliados no componente Fatores Ambientais

\begin{tabular}{|c|c|c|}
\hline Domínio & Caracterização & Descrição \\
\hline I & $\begin{array}{l}\text { Produtos e } \\
\text { Tecnologia }\end{array}$ & $\begin{array}{l}\text { Produtos e substâncias para consumo pessoal; } \\
\text { produtos e tecnologia para mobilidade na vida diária; } \\
\text { produtos e tecnologia para comunicação; produtos e } \\
\text { tecnologia para educação, cultura e lazer e produtos e } \\
\text { tecnologia usados em projetos, arquitetura e } \\
\text { construção de edifícios para uso público/privado. }\end{array}$ \\
\hline II & $\begin{array}{l}\text { Condições de } \\
\text { Moradia e } \\
\text { Mudanças } \\
\text { Ambientais }\end{array}$ & $\begin{array}{l}\text { Nível de vulnerabilidade e risco social do território de } \\
\text { moradia; e situação e condição de moradia. }\end{array}$ \\
\hline III & $\begin{array}{l}\text { Apoio e } \\
\text { Relacionamentos }\end{array}$ & $\begin{array}{l}\text { Apoio e proteção da família; apoio e relacionamentos } \\
\text { com conhecidos, companheiros, colegas, vizinhos e } \\
\text { membros da comunidade; apoio e relacionamento com } \\
\text { profissionais da educação, saúde e cuidadores; e } \\
\text { condições familiares que interferem na disponibilidade } \\
\text { de apoio e relacionamentos. }\end{array}$ \\
\hline IV & $A$ & $\begin{array}{l}\text { Vive situações de atitudes preconceituosas, } \\
\text { discriminatória e/ou negligentes de conhecidos, } \\
\text { companheiro, colegas, vizinhos, membros da } \\
\text { comunidade, profissionais de saúde e de educação e } \\
\text { outros. }\end{array}$ \\
\hline V & $\begin{array}{l}\text { Serviços, } \\
\text { Sistemas e } \\
\text { Políticas }\end{array}$ & $\begin{array}{l}\text { Serviços, sistemas e políticas dos serviços públicos; de } \\
\text { transporte; de políticas legais; de saúde; de educação } \\
\text { e treinamento; e de assistência social. }\end{array}$ \\
\hline
\end{tabular}

Fonte: Brasil, 2007d, p. 68. Elaboração própria.

Já no componente Atividade e Participação, existem quatro domínios a serem 
avaliados pelo assistente social, tais sejam: 1. vida doméstica; 2. relação e interações pessoais; 3. áreas principais da vida; 4. vida comunitária, social e cívica.

Quadro 4 - Domínios que são avaliados no componente Atividade e Participação

\begin{tabular}{|l|l|l|}
\hline Domínio & Caracterização & \multicolumn{1}{|c|}{ Descrição } \\
\hline VI & Vida Doméstica & $\begin{array}{l}\text { Tem problema em realizar atividade e ter } \\
\text { responsabilidades relacionadas a vida doméstica e de } \\
\text { cooperar com os demais membros da família. }\end{array}$ \\
\hline VII & $\begin{array}{l}\text { Relação e } \\
\text { Interações } \\
\text { Interpessoais }\end{array}$ & $\begin{array}{l}\text { Tem problema para se relacionar com os outros; } \\
\text { Mantém relações sociais, interagindo com afeto e } \\
\text { respeito nos relacionamentos. }\end{array}$ \\
\hline VIII & $\begin{array}{l}\text { Tem problema em realizar atividades e cumprir as } \\
\text { responsabilidades relacionadas à escola; coopera com } \\
\text { os demais alunos; em participar de programas } \\
\text { educacionais para graduação ou nível superior; em } \\
\text { realizar transações econômicas básicas, utilizando } \\
\text { dinheiro para efetivar compras ou troca de } \\
\text { mercadorias. }\end{array}$ \\
\hline Áreas Principais \\
da Vida
\end{tabular}

Fonte: Brasil, 2007d, p. 69. Elaboração própria.

Não são todas as pessoas com deficiência que serão avaliadas em todos esses domínios. Para realizar a avaliação social, também será levada em consideração a idade da pessoa com deficiência requerente ao BPC, critério que irá orientar quais os domínios serão avaliados. Nesse sentido,

\footnotetext{
quando a pessoa com deficiência tiver 16 anos ou mais de idade: avaliar quatro domínios: vida doméstica, relação e interações interpessoais, áreas principais da vida e vida comunitária, social e cívica.

quando a pessoa com deficiência tiver mais de 03 anos de idade e menos de 16 anos: avaliar três domínios: relação e interações interpessoais, áreas principais da vida e vida comunitária, social e cívica.

quando a pessoa com deficiência tiver até 03 anos de idade: avaliar dois domínios: relação e interações interpessoais e áreas principais da vida (BRASIL, 2007d, p. 34).
}

Orientado pela CIF, o instrumento de avaliação social conta com um qualificador no processo de avaliação social que é um valor em escala que indica a presença e gravidade de um problema em funcionalidade nos níveis pessoal ou social.

Para os Fatores Ambientais, o qualificador indica a presença de obstáculo ou barreira em uma escala de 0 a 4, que aponta o grau ou a gravidade da barreira. Barreiras são fatores 
ambientais que, por meio da sua ausência ou presença, limitam a funcionalidade e provocam a incapacidade. São avaliados aspectos como um ambiente físico inacessível, falta de tecnologia de assistência apropriada, atitudes negativas das pessoas em relação a incapacidade, bem como serviços, sistemas e políticas inexistentes ou que dificultam o envolvimento de pessoas com uma condição de saúde em várias áreas da vida (BRASIL, 2007d).

Quadro 5 - Escala para avaliar o impacto das barreiras em relação aos fatores ambientais e as dificuldades na avaliação da restrição de participação

\begin{tabular}{|l|l|l|l|}
\hline Genérico & \multicolumn{1}{|c|}{$\%$} & Atividades e Participação & Fatores Ambientais \\
\hline 0 & $0-4$ & Nenhuma Dificuldade & Nenhuma Barreira \\
\hline 1 & $5-24$ & Dificuldade Leve & Barreira Leve \\
\hline 2 & $25-49$ & Dificuldade Moderada & Barreira Moderada \\
\hline 3 & $50-95$ & Dificuldade Grave & Barreira Grave \\
\hline 4 & $96-100$ & Dificuldade Total & Barreira Total \\
\hline \multicolumn{2}{|l}{ Fonte: CIF apud Brasil, 2007d, p. 43. }
\end{tabular}

Para o componente Atividades e Participação, o qualificador indica a presença de uma dificuldade utilizando a mesma escala. Para os domínios do componente Atividades e Participação, dois importantes princípios são oferecidos: desempenho e capacidade. Juntos, estes possibilitam identificar a extensão ou magnitude de dificuldade que um indivíduo apresenta (BRASIL, 2007d).

O qualificador de capacidade descreve a habilidade ou condição de um indivíduo para executar uma tarefa ou desenvolver uma ação.

Existindo dificuldades em executar atividades, podemos dizer que existem limitações de atividade, definida na CIF como sendo dificuldades que um indivíduo pode encontrar na execução de atividades. Existindo dificuldade de participação na vida social, podemos dizer que existem restrições de participação definida na CIF como sendo: problemas que o indivíduo pode experimentar no envolvimento em situações da vida.

Os instrumentos técnico-operativos utilizados no processo de avaliação social são: 1. a observação; 2. a documentação; 3. a abordagem; 4. a visita técnica (domiciliar e institucional); 5. a entrevista.

A observação requer do assistente social clareza e conhecimento para compreender e explicar a realidade. Não é neutra, nem um instrumento de constatação. A documentação é concebida como um instrumento que organiza e veicula informações, de interesses da população usuária e do próprio assistente social. A abordagem exige uma relação de 
horizontalidade e de respeito com o usuário (BRASIL, 2007d).

A visita técnica compreende a visita domiciliar e a visita institucional. A visita domiciliar deve ser objetivada como um instrumento facilitador para emissão da avaliação social. Deve ser realizada nas situações de impossibilidade de comparecimento do requerente ou quando o assistente social necessitar de subsídios para o seu estudo. Deve, sempre que possível, ser agendada com o usuário, familiares e/ou representante legal, evitando o fator "surpresa" e situações vexatórias e constrangedoras. Não tem a intenção fiscalizadora. A visita institucional deve ser realizada quando o requerente/usuário encontrarse na situação de internado em hospital ou em instituição de longa permanência e sem condições de comparecer ao local da realização da avaliação. Pode ainda ser realizada, quando o assistente social necessitar manter contato com profissionais de determinadas instituições (hospitais, conselhos tutelares, entre outros) para obter informações complementares necessárias à conclusão da avaliação social (BRASIL, 2007d).

A entrevista é instrumento primordial do fazer profissional do assistente social no momento de realização da avaliação social, que se concretiza por meio do atendimento individual ao usuário, aos familiares e/ou o representante legal, com a finalidade de obter elementos relevantes para subsidiar o estudo e a análise das condições pessoais, do ambiente físico e social que impactam na funcionalidade e incapacidade. Exige do profissional conhecimento e habilidade, evitando-se situações vexatórias e constrangedoras (BRASIL, 2007d).

Em meio a tantas mudanças no acesso ao BPC para pessoas com deficiência, principalmente pela introdução da avaliação social para saber qual pessoa com deficiência tem direito ao benefício, é possível afirmar que existem várias dúvidas no processo de avaliação social. Conhecer todo o processo é uma tarefa complexa, exige um profissional competente do ponto de vista teórico-metodológico, técnico-operativo e ético-político, conforme aponta as Diretrizes Curriculares da Associação Brasileia de Ensino e Pesquisa em Serviço Social (ABEPSS) (1996). É preciso pesquisar esse novo método de avaliação, conhecer quais as dificuldades e os desafios encontrados pelas assistentes sociais quando estão frente a uma pessoa com deficiência requerente ao BPC, pois dessa forma será possível apontar novos direcionamentos para minimizar cada vez mais as arbitrariedades ainda muito presente em todo o processo de concessão do benefício e expandir o BPC, valorizando a importância dos fatores ambientais e a participação social no momento de avaliação da pessoa com deficiência que requere o benefício.

Podemos, então, entender avaliação social como um instrumento técnico-operacional que tem a finalidade de realizar o estudo e emitir a opinião profissional sobre o grau de barreiras existente em relação aos fatores contextuais, ou seja, as condições pessoais e do 
ambiente físico, social e de atitude onde vive o indivíduo e o grau das dificuldades existentes em relação à atividade e participação. Construído com base nos princípios da CIF, a avaliação social possibilita identificar situações que interferem na funcionalidade e na incapacidade do indivíduo, que buscam o acesso ao BPC.

Por atender um grande contingente populacional sem exigir contribuições prévias ao sistema de seguridade social, o BPC apresenta-se como um programa de grande importância no Brasil que possui um mercado de trabalho marcado pela informalidade e desemprego bem altos. A avaliação social é um novo instrumento que busca superar a limitação anteriormente vigente que avaliava a deficiência apenas nos seus aspectos biomédicos. A CIF e os novos decretos que regulamentam o BPC tentam minimizar injustiças no momento de acesso ao benefício para pessoas com deficiência, incorporando elementos sociais, ambientais e avaliação da participação das pessoas com deficiência na sociedade. O que ocorreu foi uma guinada em relação ao processo avaliativo para saber qual pessoa com deficiência possui direito ao benefício, um reconhecimento que era preciso ir além do critério corporal, sobretudo avaliar a relação deficiência e sociedade. Isso gerou um forte impacto no único benefício da política de assistência social antes prevista na CF/1988, o que hoje gera grandes desafios na operacionalização do BPC. No próximo capítulo, iremos conhecer um pouco da trajetória do assistente social no INSS, assim como analisar alguns desafios colocados pelas profissionais quando realizam a avaliação social. 


\section{CAPÍTULO 3}

\section{SERVIÇO SOCIAL E OS DESAFIOS DA AVALIAÇÃO SOCIAL}

\subsection{O Serviço Social Previdenciário}

A compreensão da trajetória do Serviço Social previdenciário nesse trabalho justificase porque são os/as assistentes sociais do INSS que realizam a avaliação social para acesso ao BPC. A partir da análise dos projetos profissionais orientadores do trabalho dos assistentes sociais em diferentes momentos históricos, queremos recuperar um pouco dessa trajetória do Serviço Social na previdência social. Para realizarmos essa análise, tomamos como referência os projetos profissionais dos Planos de Ação do Serviço Social dos anos de 1972 e de 1978 e a Matriz Teórico-Metodológica do Serviço Social no INSS publicada em 1994 (SILVA, 2008).

$\mathrm{Na}$ intenção de entendermos melhor a trajetória do Serviço Social na política previdenciária, apresentamos um quadro esquemático a partir da década de 1940.

Quadro 4 - Cronologia do Serviço Social na previdência social

\begin{tabular}{|l|l|}
\hline 1942 & Seção de Estudos e Assistência Social no IAPC. \\
\hline 1944 & $\begin{array}{l}\text { Autorização para a implantação de Serviço Social nos IAPs e CAPs - Portaria } n^{0} . \\
\text { 52 do Conselho Nacional do Trabalho (CNT). }\end{array}$ \\
\hline 1945 & $\begin{array}{l}\text { Organização de cursos intensivos de Serviço Social para os funcionários dos IAPs } \\
\text { e CAPs - Portaria do DNPS/MT. }\end{array}$ \\
\hline 1948 & $\begin{array}{l}\text { Adoção do Serviço Social nas instituições de previdência: assistência } \\
\text { complementar - Ofício n }{ }^{0} \text {. 250/DNPS. }\end{array}$ \\
\hline 1948 & Oficialização do Serviço Social no IAPC em São Paulo. \\
\hline 1950 & Seções ou turma de Serviço Social nas Delegacias Regionais dos IAPs. \\
\hline 1960 & Definição da assistência complementar na Lei Orgânica da Previdência Social. \\
\hline 1965 & Concepção do Serviço Social como assistência complementar. \\
\hline 1972 & Plano Básico de Ação do Serviço Social - Resolução INPS n ${ }^{0} .401 .4$. \\
\hline 1976 & $\begin{array}{l}\text { Assistência complementar por meio do Serviço Social - Art. 71 da Consolidação } \\
\text { das Leis da Previdência Social. }\end{array}$ \\
\hline 1978 & Plano Básico de Ação do Serviço Social - Resolução INPS n ${ }^{0}$. 064.2. \\
\hline 1991 & $\begin{array}{l}\text { Competência do Serviço Social: esclarecimento quanto aos direitos sociais e } \\
\text { meios de exercê-los; ações intra e extra-institucionais - Art. 88 da Lei n }{ }^{0} .8 .213 \text { de } \\
\text { 24/07/1991. }\end{array}$ \\
\hline
\end{tabular}


1994 Matriz Teórico-Metodológica do Serviço Social na Previdência Social.

Fonte: Silva, 2008, p. 20-1.

A primeira experiência oficial de implantação do Serviço Social na previdência social ocorreu por meio da Seção de Estudos e Assistência Social no Instituto de Aposentadorias e Pensões dos Trabalhadores do Comércio (IAPC) em 1942. São, então, 68 anos de história do chamado Serviço Social previdenciário (SILVA, 2008).

Foi, então, a partir do governo de Getúlio Vargas que o Serviço Social previdenciário recebeu um sopro de vida, em um momento em que a previdência social passava a ter importância como expressão da ofensiva do governo autoritário, populista, corporativo e gestor das relações de trabalho, tendo como marcos a criação dos Institutos de Aposentadorias e Pensões (IAPs) (ABREU e LOPES, 2008; BOSCHETTI, 2006).

O Serviço Social na previdência social só foi institucionalizado seis anos após sua primeira experiência no IAPC por meio do Ofício Circular $n^{0} .250 / 1948$, expedido pelo então diretor-geral do Departamento Nacional de Previdência Social, Moacir Veloso Cardoso de Oliveira. Esse Ofício orientava para adoção das seguintes medidas que deveriam ser adotadas pelas instituições da previdência: 1. organização de seções de Serviço Social; 2. lotação nas seções dos servidores com curso regular de assistência social ou com curso intensivo de "auxiliar social"; 3. controle do registro de entrada e saída dos servidores, observadas as necessidades dos "trabalhos de serviço social"; 4. colaboração dos diversos órgãos da instituição; 5. não aumento de despesa quanto a pessoal pelo aproveitamento dos servidores já disponíveis; 6 . concessão de bolsas de estudo para o preparo de novos servidores (SILVA, 2008).

O Serviço Social previdenciário historicamente parece ser reduzido a uma mera assistência complementar importante tanto para o futuro da previdência social quanto no sentido da individualização do benefício a fim de poder prestar apoio à solução dos problemas dos desajustamentos sociais no Brasil. Essa afirmação encontra fundamento nas atividades que foram atribuídas ao Serviço Social na previdência no final da década de 1940: 1. orientação quanto aos benefícios e à obtenção de documentos, tutelas, registros de nascimento, etc.; 2. orientação social nas casas dos segurados; 3. encaminhamento de segurados a outras instituições públicas ou privadas quando uma demanda não esteja no âmbito da previdência social; 4. estudo e exame dos casos individuais de desajustamento dos segurados e beneficiários e seu acompanhamento por meio de visitas periódicas e registro em fichas reservadas, uma função de ajuda, quando identificada a dificuldade ou impossibilidade de agir do segurado (SILVA, 2008; NEVES e SILVA, 2008; IAMAMOTO e CARVALHO, 2005).

Essas atividades contribuíram para ratificar a configuração da individualização dos 
benefícios e a humanização da ação educativa a ser desenvolvida pelos assistentes sociais (IAMAMOTO e CARVALHO, 2005).

Durante décadas, o Serviço Social previdenciário seguiu a orientação "complementar, supletiva, individualizante, humanizante, educativa em torno da previdência social, tendo como objeto o ajustamento social" (SILVA, 2008, p. 22). O termo complementar, que parece caracterizar certo status de estigma ao Serviço Social previdenciário, tem diferentes significados: o de satisfação de necessidades que o mercado não satisfaz; o de que as necessidades, no caso, são realmente residuais no âmbito da reprodução social; o de provisão de necessidades que o trabalhador e sua família não são capazes de prover por si mesmos (PEREIRA, 2006).

O entendimento de Serviço Social como algo complementar na previdência social foi confirmado por meio da Lei $n^{0}$. 3.807/1960 - Lei Orgânica da Previdência Social (LOPS) que, então, definiu a assistência complementar:

Art. 22. As prestações asseguradas pela previdência social consistem em benefícios e serviços, a saber: I - Quanto aos segurados: a) auxílio-doença; b) aposentadoria por invalidez; c) aposentadoria por velhice: d) aposentadoria especial; e) aposentadoria por tempo de serviço; f) auxílio-natalidade; g) pecúlio; h) assistência financeira. II - Quanto aos dependentes: a) pensão; b) auxílio-reclusão; c) auxíliofuneral; d) pecúlio. III - Quanto aos beneficiários em geral: a) assistência médica; b) assistência alimentar; c) assistência habitacional; d) assistência complementar; e e) assistência reeducativa e de readaptação profissional.

Art. 52. A assistência complementar compreenderá a ação pessoal junto aos beneficiários, quer individualmente, quer em grupo, por meio da técnica do Serviço Social, visando à melhoria de suas condições de vida.

$\S 1^{0}$. A assistência complementar será prestada diretamente ou mediante acordo com os serviços e associações especializadas.

$\S 2^{0}$. Compreende-se na prestação da assistência complementar a de natureza jurídica, a pedido dos beneficiários ou "ex-oficio" para a habilitação aos benefícios de que trata esta lei e que deverá ser ministrada, em juízo ou fora dele, com isenção de selos, taxas, custas e emolumentos de qualquer espécie (BRASIL, 1960).

Muito embora o Serviço Social já se fizesse presente de alguma forma na previdência social há dezoito anos (1942-1960), ainda existia uma ausência em termos jurídicos do que seria o Serviço Social na previdência, um ranço, que já podemos anunciar, ainda presente no Serviço Social previdenciário hoje que veremos mais adiante como um dos desafios da avaliação social para acesso ao BPC.

Cinco anos após a promulgação da LOPS/1960, foram detalhadas as Normas Gerais para o Serviço Social na previdência. Para os que tinham alguma dúvida, a Resolução de 1965 formalizou o Serviço Social na previdência como

assistência complementar que através de métodos, instrumentos e técnicas próprias: I - atende os beneficiários carentes de ajuda, individualizando e tornando humanas as relações com a Instituição na concessão e manutenção das prestações 
asseguradas pela Lei; II - contribui pela atuação junto aos setores da Instituição incumbidos das prestações, para que estas não tenham apenas caráter paliativo, mas sejam rela fator de ajustamento social; III - previne e corrige desajustamentos através de atuação direta na família, no trabalho e na comunidade (MTPS, 1965, Art. $3^{\circ}$.).

A resolução 1.081/1965 não conseguiu ultrapassar a noção de prevenção e correção de desajustamentos por meio da atuação direta na família, no trabalho e na comunidade. Aos profissionais que ainda precisavam de um instrumento jurídico mais explícito da perspectiva funcionalista, foi lançado o Regulamento Geral da Previdência Social, em 1973, que reiterou a ajuda pessoal nos desajustamentos individuais e do grupo familiar em seu artigo 180 (FALEIROS, 2008).

O Serviço Social previdenciário da década de 1970 não conseguiu ir além da mera reprodução das ideias de seu tempo histórico. As práticas tradicionais continuaram sem qualquer tipo de questionamento. O trabalho, totalmente orientado pelo Movimento de Reconceituação do Serviço Social ${ }^{3}$, era descobrir instrumentos de acordo com a realidade sem chegar a um questionamento das estruturas sociais vigentes e continuando a ter como referencial teórico o funcionalismo.

Embora o Movimento de Reconceituação do Serviço Social tenha surgido como um movimento de revisão e crítica na década de 1960, com pretensões a romper com o metodologismo tradicional que caracterizava o Serviço Social de origem norte-americana anacrônico à realidade histórica, social, econômica e política latinoamericana (MACEDO, 1986), a crítica de Netto (2007) identifica tal movimento como a

\begin{abstract}
perspectiva modernizadora, um esforço no sentido de adequar o Serviço Social, enquanto instrumento de intervenção inserido no arsenal de técnicas sociais a ser operacionalizado no marco de estratégias de desenvolvimento capitalista, às exigências postas pelos processos sociopolíticos emergentes no pós-64. Trata-se de uma linha de desenvolvimento profissional que, se encontra o auge da sua formulação exatamente na segunda metade dos anos sessenta, sem dúvidas, são os textos dos seminários de Araxá e Teresópolis, revelar-se-á um eixo de extrema densidade na reflexão profissional: não só continuará mobilizando energias nos anos seguintes, como, especialmente, mostrar-se-á aquele vetor de renovação que mais fundamente vincou a massa da categoria profissional (NETTO, 2007, p. 154).
\end{abstract}

3 Aguiar (1982) explicita que, no início da década de 1960, grupos de assistentes sociais passam a questionar o Serviço Social quanto a sua natureza e operacionalidade. Esse questionamento é o da validade do corpo teórico do Serviço Social em face à realidade da América Latina. No Brasil, esse questionamento se fez por um número significativo de assistentes sociais, quer pelos que estavam comprometidos com os programas do governo, mas que desejavam reformas, quer por aqueles mais ligados com o povo. Coloca-se que um dos aspectos da reconceituação é o de sistematizar as experiências para reelaborar, a nível latinoamericano, uma teoria própria de Serviço Social. Um grupo de assistentes sociais preocupados com essa nova realidade passou a ser conhecido como a "geração 65". Esse movimento nasceu para adequar o Serviço Social para a América Latina e tinha como referência o desenvolvimentismo. Um importante teórico que merece ser destacado, Lucena Dantas, também se preocupa em adequar a metodologia para a realidade brasileira. O Movimento de Reconceituação no Brasil tem o seu início como o Primeiro Seminário de Teorização do Serviço Social, promovido pelo Centro Brasileiro de Cooperação e Intercâmbio de Serviços Sociais (CBCISS), que convocou um grupo de 38 assistentes sociais para uma semana de estudos sobre "Teorização do Serviço Social". Esse encontro aconteceu em março de 1967, em Araxá, Minas Gerais, momento em que foi resolvido discutir um roteiro sobre conceitos básicos e estudar a metodologia sob um prisma genérico, ao invés da dinâmica dos processos. Após o Seminário, houve a publicação do que se chama Documento de Araxá. 
O núcleo central da Reconceituação é a tematização do Serviço Social como interveniente, dinamizador e integrador no processo de desenvolvimento. O que caracteriza esta perspectiva está longe de resumir-se à exclusão de tendências contestadoras: antes, o que lhe confere seu tônus peculiar é a nova fundamentação de que se socorre para legitimar o papel e os procedimentos profissionais. Constatam-se reiterações da tradição, registramse avanços inequívocos, com aportes extraídos do estrutural-funcionalismo norteamericano. Este é o caráter modernizador desta perspectiva: ela aceita como dado inquestionável a ordem sociopolítica derivada do golpe militar de 1964 e procura dotar a profissão de referências e instrumentos capazes de responder às demandas que se apresentam nos seus limites, uma característica tecnocrática do perfil que pretende atribuir ao Serviço Social no país. No âmbito estrito da profissão, a "modernização" se reporta aos seus valores e concepções mais tradicionais, não para superá-los ou negá-los, mas para inseri-los numa moldura teórica e metodológica menos débil, subordinando-os aos seus vieses modernos do lastro eclético de que é portadora. Seu traço conservador e sua colagem à ditadura incompatibilizam-na com os segmentos profissionais críticos quer em face da burguesia, quer em face dos seus substratos teóricos - segmentos cuja incidência acadêmica e na categoria profissional ganha tanto mais densidade quanto mais a autocracia burguesa experimenta o seu ocaso (NETTO, 2007).

A expressão do Movimento de Reconceituação no Serviço Social previdenciário, então, foi marcada pela ilusão e integração social. O desenvolvimento não passou de interpelação ideológica, representou não mais que uma ilusão.

O Plano Básico de Ação do Serviço Social no então Instituto Nacional de Previdência Social (INPS) foi aprovado por meio da Resolução INPS $n^{0} .401 .4$, de 07/02/1972, seguido da Padronização de Documentação Técnica - Sistema Básico de Registro de Dados. O Plano de 1972 é uma das mais significativas expressões da perspectiva modernizadora no exercício da prática profissional de então (FALEIROS, 2008). O plano pressupõe

\footnotetext{
a capacidade para tomada de decisões, com o fim de selecionar e nortear as atividades do Serviço Social no INPS, construindo-se, no seu todo, uma tentativa de unificar teorias emanadas da prática. É, outrossim, fundamental que ele represente junto às demais linhas de atividades do INPS, a interpretação do papel do Serviço Social na instituição considerando-se como papel o conjunto de expectativas em torno de determinada função no sistema social. Essas expectativas devem corresponder aos objetivos do Instituto, às finalidades do Serviço Social e às necessidades da clientela (INPS, 1972, p. 6).
}

A função do Serviço Social vai se expressar na racionalidade técnica e administrativa do enfoque assistencialista da política previdenciária. O projeto profissional que se define nesses marcos reafirma-se como ação político-pedagógica com orientação individualista e psicossocial, tendo a prestação e administração de serviços como a principal referência 
material, ao mesmo tempo em que reforça e contribui para o ocultamento dos processos de racionalização desses serviços nos limites do padrão burocrático do assistencialismo implantado pela ditadura militar (FALEIROS, 2008; ABREU e LOPES, 2008).

O Serviço Social previdenciário, então, com o Plano de 1972, foi reduzido a uma "ação educativa individualizada, subalternizante, centrada na necessidade de manutenção do trabalhador e sua família em permanente estado de necessidade em relação aos meios de sua subsistência física" (INPS, 1972, p. 15).

O projeto profissional do início da década de 1970, ao incidir sobre as manifestações individuais da "Questão Social", reduzida a suas expressões psicossociais, reatualizou princípios tradicionais da individualização e da autodeterminação do sujeito, que tendem a respaldar a pulverização do atendimento às demandas sociais e legitimar a ênfase no esforço individual na busca de respostas às suas necessidades imediatas (IAMAMOTO, 2008).

A partir de 1977, a "assistência social previdenciária" foi definida como atividade autônoma, exigindo (re)estruturação no âmbito nacional em face da extensão e peculiaridade dos serviços que deverá prestar. O final da década de 1970 ocorreu uma valorização da assistência social do MPAS e superestimou as possibilidades profissionais do Serviço Social:

há apenas um reduzido contingente da população, em termos percentuais, permanecendo marginalizada no tocante à proteção social, mas mesmo esse contingente de pessoas carentes deverá ser um dia redimido graças à programação prevista pra o setor de assistência social do MPAS (SILVA, 2008, p. 27).

Em um contexto de ditadura militar, com restrições de direitos políticos, o Serviço Social é superdimensionado em face da complexidade e da gravidade da "Questão Social" (NETTO, 2007). Na verdade, percebe-se que ainda se tinha mais do mesmo para o Serviço Social previdenciário: uma "ilusão integradora com termos que remetiam para um campo mágico, para uma suposta capacidade redentora da assistência social" (MOTA, 2010, p. 138).

A ilusão integradora continuou a sobreviver com o lançamento do Plano Básico de Ação do Serviço Social de 1978 que, conforme assinalado por Pereira (1978), apresenta ainda um Serviço Social

selecionado para seu sistema cliente, não apenas a pessoa do beneficiário, mas também o seu meio ambiente [...] nossa prática no INPS é orientada na busca da integração social do beneficiário e reconhece as implicações da interação (pessoa em situação), e que esta prática se situa no "social abrangente", que compreende a realidade social através da identificação de categorias de fenômenos que são: psicossociais, socioculturais, socioeconômicos, etc., e que esses fenômenos são tomados na dimensão da interação social das relações sociais (PEREIRA, 1978, p. 304). 
O Plano Básico de Ação para o Serviço Social, RS/INPS n0. 064.2/1978, a partir da perspectiva funcionalista do tratamento psicossocial, superdimensionada em suas possibilidades, tentava buscar "a solução de problemas que impediam a integração social de grupos que se apresentavam em processo de adaptação ao meio urbano". Na verdade, buscava-se encontrar solução para o processo de acumulação nas grandes cidades e o equacionamento dos "profundos desequilíbrios entre os recursos sociais existentes e a demanda de serviços" (PEREIRA, 1978, p. 300, 312-3).

O que fica evidente é uma tendência de se entender os serviços prestados pelo Serviço Social na previdência mais como dever moral de ajuda, não como direito (PEREIRA, 2006). O ajustamento social sob a abordagem psicossocial e a integração social, tendo como foco a interação da pessoa ao meio ambiente é o caminho encontrado pelo Serviço Social previdenciário das décadas de 1970 e 1980.

As críticas aos Planos Básicos de 1972 e de 1978 podem ser assim resumidas:

\begin{abstract}
enquanto o Serviço Social definir sua política de ação e formular programas a partir do conhecimento imediato da política previdenciária e institucional, sem buscar conhecer seus motivos reais, distorções continuarão a existir, tornando cada vez mais difícil a identificação da programação do Serviço Social com a clientela. É necessário duvidar. Procurar conhecer as relações que está por trás, compreender, portanto, as relações entre as classes e a mediação do Estado como determinantes no estabelecimento da política previdenciária, sendo esta uma manifestação da política trabalhista adotada pelos governos em cada período histórico. Caso contrário, as programações do Serviço Social continuarão apenas dando respostas às exigências da Instituição (CABRAL apud SILVA, 2008, p. 30-1).
\end{abstract}

Essa perspectiva integradora isenta de um debate crítico não pode ser aceita por um Serviço Social que aspira ir além de uma atitude adaptativa. Nesse sentido, a preocupação vai além do como fazer e se volta para a direção que toma o conhecimento em produção (IAMAMOTO, 2008). Segundo Cartaxo (1995, p. 143), "importa entender a questão pelas condições mais amplas, em seus elementos estruturais e conjunturais, assim como pela ineficiência do próprio organismo previdenciário".

Na década de 1990, de acordo com Moreira (2008), o Serviço Social previdenciário passa a expressar os avanços consubstanciados na CF/1988 em torno dos direitos sociais e da participação dos usuários na gestão das políticas sociais. A Lei $n^{0}$. 8.213, de 24 de julho de 1991, que dispõe sobre os Planos de Benefícios da Previdência Social, foi capaz de revelar a competência do Serviço Social no âmbito da política previdenciária.

Art. 88. Compete ao Serviço Social esclarecer junto aos beneficiários seus direitos sociais e os meios de exercê-los e estabelecer conjuntamente com eles o processo de solução dos problemas que emergirem da sua relação com a previdência social, tanto no âmbito interno da instituição como na dinâmica da sociedade.

$\S 1^{0}$. Será dada prioridade aos segurados em benefício por incapacidade temporária 
e atenção especial aos aposentados e pensionistas.

$\S 2^{0}$. Para assegurar o efetivo atendimento dos usuários, serão utilizadas intervenção técnica, assistência de natureza jurídica, ajuda material, recursos sociais, intercâmbio com empresas e pesquisa social, inclusive mediante celebração de convênio, acordos ou contratos.

$\S 3^{0}$. O Serviço Social terá como diretriz a participação do beneficiário na implementação e no fortalecimento da política previdenciária, em articulação com as associações e entidades de classe.

$\S 4^{0}$. O Serviço Social, considerando a universalização da previdência social, prestará assessoramento técnico aos Estados e Municípios na elaboração e implantação de suas propostas de trabalho (BRASIL, 1991).

A partir de 1991, na análise de Silva (2008), as atividades do Serviço Social ganham espaço nos âmbitos internos e externos. No interno, ficaram destinadas as seguintes ações para o Serviço Social: prestação e socialização das informações previdenciárias, articulação com os setores da Instituição, prestação de recursos materiais e emissão de laudo e parecer social. No âmbito externo, o Serviço Social do INSS ficou responsável pela articulação com as associações, entidades de classe, sindicatos, empresas, obras sociais e outros recursos, por meio da criação de canais contínuos que possibilitem a discussão e análise dos direitos sociais e da política previdenciária, a inclusão dos trabalhadores na participação, implementação e fortalecimento da mesma.

A prestação e socialização das informações previdenciárias constituem um trabalho social que possibilita ao usuário a decodificação da lei e de seus procedimentos burocráticos para facilitar ao usuário o acesso aos benefícios e serviços e, ao mesmo tempo, possibilitar uma análise crítica das questões previdenciárias (MOREIRA, 2008).

Essa guinada na principal atividade no Serviço Social previdenciário a partir da década de 1990 aponta para um avanço do projeto de profissão na previdência social ancorado a uma concepção de projeto societário com uma perspectiva voltada para os interesses imediatos e históricos da classe trabalhadora (MOREIRA, 2008; CARTAXO e CABRAL, 2008).

A concepção de projeto profissional articulada a um projeto societário emancipatório tem no Código de Ética do Assistente Social (1993), na Lei de Regulamentação da Profissão (1993) e nas Diretrizes Curriculares da ABEPSS (1996), uma nova legalidade reafirmada na década de 1990, orientada por uma nova direção social hegemônica do Serviço Social nos anos de 1980. O projeto profissional e sua direção sociopolítica têm sua influência decisiva nas lutas e movimentos sociais em uma perspectiva classista em que o trabalho profissional vai perfilando uma nova configuração no interior da contradição capital-trabalho (IAMAMOTO e CARVALHO, 2005; CARTAXO e CABRAL, 2008).

O movimento de ruptura do Serviço Social na previdência ocorreu uma década após a ruptura pública e coletiva da profissão, que tem no III Congresso Brasileiro de Assistentes 
Sociais (1979) sua referência emblemática (IAMAMOTO, 2008). Foi na década de 1990 que se consolidou, na previdência social, a maturidade teórico-profissional do projeto de ruptura que se materializou na Matriz Teórico-Metodológica do Serviço Social (1994) na previdência social que orienta a ação profissional. Essa Matriz declarou o compromisso de ruptura do Serviço Social com o modelo tradicional na previdência social e assumiu nova identidade pela aproximação com o discurso hegemônico da profissão, o projeto ético-político profissional (CARTAXO e CABRAL, 2008).

A Matriz de 1994 apresentou um novo paradigma para o Serviço Social na área da previdência social que reestrutura o fazer profissional do Serviço Social na área e vai se constituir um marco na história da profissão na previdência, revelando "uma opção clara e fundamentada pelos princípios democráticos que buscam recuperar e resgatar o exercício da cidadania e do direito" (INSS, 1994, p. 7).

Com a Matriz, um novo sopro de vida foi dado ao Serviço Social previdenciário, um sopro bem diferente de cinquenta anos atrás. Esse documento surge como contraposição às orientações funcionalista/ajustadora dos velhos Planos de Ação de 1972 e 1978 que durante anos orientaram a prática dos assistentes sociais da previdência social. A partir da metade da década de 1990 foi iniciado um embate com as forças institucionais conservadoras que foi capaz de traçar uma trajetória diferenciada, construída a partir de uma apreensão crítica da realidade. Esse novo paradigma vai apoiar-se no método crítico dialético, apresentando como fundamento novas bases teóricas, estratégicas, éticas e legais para a ação profissional, sendo orientado por uma concepção de previdência social como direito (MOREIRA, 2008; SILVA, 1999).

O debate avançou em algumas dimensões, como: 1. a compreensão do Serviço Social inserido no processo de reprodução das relações sociais; 2. a explicitação das demandas colocadas socialmente ao Serviço Social e das necessidades sociais a que a profissão busca responder pelo caráter contraditório da prática profissional; 3. a análise do trabalho do assistente social e de algumas de suas particularidades como a vinculação histórica com a assistência social; 4. as bases legais do Serviço Social (IAMAMOTO e CARVALHO, 2005; CARTAXO e CABRAL, 2008).

A Matriz trouxe muitas mudanças para o Serviço Social previdenciário e afirmou que

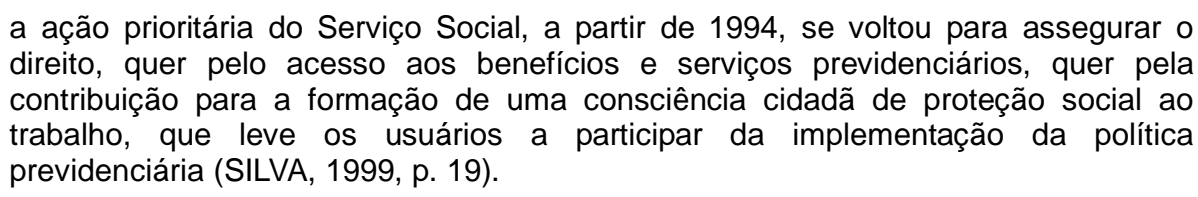

Silva (1999) informa que essa competência foi concretizada por meio de ações profissionais coordenadas pela Divisão de Serviço Social (DSS) extinta em junho de 1999 
pelo decreto $\mathrm{n}^{0}$. 3.081/1999. Foi no contexto da "contrarreforma do Estado" (BEHRING, 2003) que a cobertura e o acesso aos direitos da política previdenciária sofreram grave queda, momento também que foi posta em discussão a existência do Serviço Social no INSS.

Silva (1999) aponta dois momentos importantes que contribuíram na luta da categoria e da sociedade pela permanência do Serviço Social no INSS: 1. em dezembro de 1998, quando, como parte da contrarreforma, foi publicada a Medida Provisória 1.729, cujo texto continha, dentre outros assuntos, a extinção do Serviço Social do INSS. Tal medida indignou o Serviço Social e a sociedade pela forma autoritária e não transparente como foi editada. A DSS só tomou conhecimento da medida por meio do Diário Oficial da União. Toda a categoria profissional se mobilizou, articulada com entidades e personalidades políticas da sociedade civil. Em dois dias, mais de 220 organizações da sociedade, manifestaram-se pela exclusão dos artigos referentes ao Serviço Social da MP. A capacidade de mobilização da categoria e da sociedade em torno da MP 1.729/1998 significou uma vitória parcial do Serviço Social e usuários desse serviço; 2. o período decorrido entre a mobilização pela alteração do conteúdo da MP 1.729/1998 e o que antecedeu a publicação do decreto 3.081/1999: foram mobilizadas mais de 1800 organizações da sociedade civil, incluindo personalidades políticas, das quais 931 manifestaram-se, enviando defesas escritas pela permanência do Serviço Social no INSS e representantes do governo.

A mobilização da categoria dos assistentes sociais em relação à permanência do Serviço Social na previdência repercutiu no Ministério da Previdência e Assistência Social que recuou da extinção definitiva do Serviço Social, conforme pretendeu com a MP 1.729/1998, mantendo-o como atividade no âmbito do INSS (LOPES, 1999).

Tanto na análise de Silva (1999) quanto de Cartaxo e Cabral (2008), as demandas contemporâneas que desafiam o Serviço Social previdenciário estão orientadas para ações e projetos que possuem como principais objetivos a confirmação da previdência social como um direito do cidadão; a ampliação da visibilidade interna e externa do Serviço Social; o fortalecimento das articulações com outros setores da instituição; o engajamento com os movimentos sociais e organizações da sociedade civil.

A luta do Serviço Social previdenciário, conforme Cartaxo e Cabral (2008), também está na recomposição do espaço sócio-ocupacional em face da publicação da Portaria Interministerial $n^{0}$. 01/2007 - MPS/MDS, de 20/03/2007, que constituiu um grupo de trabalho para reestruturar este serviço, com a participação de representações do Ministério da Previdência, MDS e do CFESS.

Outra luta dos assistentes sociais da previdência e também do conjunto CFESS/CRESS, está no combate ao Projeto de Lei que regulamenta os fundos privados de 
previdência complementar criados com a Reforma Previdenciária de 2003 na perspectiva do fortalecimento da previdência privada e a Lei 11.457, que regulamenta o funcionamento da Receita Federal, com a fusão das Secretarias da Receita Previdenciária e da Receita Federal, o que implica injetar recursos da seguridade social no caixa único da União, que tem priorizado o pagamento da dívida pública. É nesse cenário de incertezas que se inscreve a reestruturação do Serviço Social previdenciário.

Muito embora uma tendência de avanço em termos teórico-metodológicos, éticopolíticos e técnico-operativos do Serviço Social na previdência nos últimos dezesseis anos, as antigas expressões do pensamento conservador não estão suprimidas da agenda político-institucional (CARTAXO e CABRAL, 2008).

Exemplo desse pensamento conservador, o progressivo desmonte da seguridade social em três diferentes tendências, tais sejam: 1. desconfiguração dos direitos previstos constitucionalmente; 2. fragilização dos espaços de participação e controle democrático previstos na CF/1988; e 3. apropriação indevida do orçamento, em que estão em disputa interesses antagônicos, a luta pela apropriação de bens, serviços e recursos sociais, talvez seja o principal desafio na relação Serviço Social e previdência social hoje (BOSCHETTI, 2008; 2009).

Em uma realidade de crise estrutural da economia mundial atual em seus aspectos global, permanente e sistêmico e de seu rebatimento sobre as políticas sociais (ACANDA, 2010), a resposta profissional é de afirmação e defesa do caráter público da previdência social, de sua universalidade e democratização enquanto política de direitos de cidadania. Os assistentes sociais da previdência social não estão alheios a esse debate e buscam resistir, no cotidiano profissional, às reformas conservadoras e lutam na construção de políticas sociais politizadas e voltadas aos direitos de cidadania de seus usuários.

\subsection{O Serviço Social, a Avaliação Social e o Desafio do Concurso Público}

A luta em defesa do Serviço Social na previdência social não é recente e se vincula à garantia de um espaço de trabalho profissional comprometido com a defesa dos direitos sociais, com a efetivação da seguridade social pública e de qualidade, consonante com a direção do projeto ético-político do Serviço Social brasileiro (CFESS, 2010a).

O Conjunto CFESS/CRESS vem sendo um dos protagonistas na defesa desse espaço sócio-ocupacional. Na gestão 2005/2008 do CFESS, foram realizadas duas audiências com o Ministério da Previdência Social, para tratar sobre o concurso público, que resultou na criação do Grupo de Trabalho (GT) pela Portaria Conjunta №. 1, de 28/03/07, do Ministério da Previdência Social e do MDS, com a participação do CFESS, conforme já 
anunciado (CFESS, 2010a).

Esse GT teve como objetivos: a) apresentar proposta de reestruturação do Serviço Social do INSS de modo a contemplar as novas exigências quanto aos serviços específicos a serem prestados à população previdenciária e àquela necessitada dos benefícios assistenciais de modo a subsidiar a realização de concurso público para profissionais da área; b) definir atribuições, competências, funções dos profissionais de Serviço Social no âmbito da previdência social a fim de readequar a estrutura existente às demandas atuais; c) propor alterações que se fizerem necessárias no que diz respeito às condições de trabalho dos assistentes sociais no INSS (CFESS, 2010a).

O GT apresentou como resultado do seu trabalho uma minuta de Decreto, que dentre outras previsões, estabelece as atribuições de assistentes sociais no âmbito do INSS, documento que foi encaminhado ao Ministério do Planejamento, Orçamento e Gestão (MPOG), e que ainda hoje se encontra nesse órgão (processo 04500.006030/2007-24).

A publicação do Decreto 6.214/2007, que estabelece a obrigatoriedade da avaliação social como parte integrante do processo de avaliação da incapacidade para a vida independente e para o trabalho das pessoas com deficiência para acesso ao BPC a partir de 2009, reforçou a necessidade do concurso público para assistentes sociais no âmbito do INSS.

Em resposta à exigência expressa pelo Decreto de 2007, inicialmente, o MPOG autorizou 600 vagas para o concurso público, insuficientes para a necessária recomposição do quadro. Foram realizadas diversas articulações e dessa forma conseguiu-se a concordância do MPOG em aumentar o número de vagas (CFESS, 2010a).

Após anos de lutas para (re)estabelecer o quadro de assistentes sociais no INSS, foi publicado no D.O.U. o Edital nº. 1, de 6 de novembro de 2008, concurso público para provimento de 900 vagas no cargo de Analista de Seguro Social com formação em Serviço Social para todo o Brasil.

O concurso realizado foi para assistente social, no âmbito do INSS, tendo como objetivo principal atender a demanda de realizar a avaliação social da deficiência e do grau de incapacidade para a vida independente e para o trabalho das pessoas com deficiência que buscam o BPC (CFESS, 2010)

As 900 vagas, embora superior a oferta inicial do MPOG, é insuficiente para o provimento do quadro de pessoal das 100 Gerências Executivas e 1.217 Agências da Previdência Social no Brasil. Antes da realização do concurso público, o INSS contava com apenas 548 profissionais, sendo que somente 270 desempenhavam suas ações nas seções específicas de Serviço Social. Os demais profissionais atuavam nos setores de Reabilitação Profissional, Recursos Humanos, exerciam cargos comissionados e/ou atuavam nos 
diversos setores do órgão. Os estudos realizados pelo GT demonstravam a necessidade de contratação de aproximadamente 1.600 profissionais para suprir as reais demandas de atendimento aos usuários das políticas da previdência e assistência social (CFESS, 2010a).

Uma grande conquista, a Portaria 450 sobre o concurso, do MPOG, admite a possibilidade de nomeação de candidatos aprovados até o limite de $50 \%$ a mais do quantitativo original de vagas, o que implica dizer que ainda existe a oportunidade de 450 assistentes sociais serem nomeados, podendo chegar ao patamar de 1.350 nomeações em todo o Brasil, número mais próximo da necessidade de profissionais apontado pelo GT (CFESS, 2010a).

A pesquisa de campo realizada em Brasília, Taguatinga e Ceilândia, cidades do Distrito Federal, foi possível pela autorização dada pela diretora da Saúde do Trabalhador do INSS, após submissão do projeto e instrumento de coleta de dados inicialmente censurado em questões relativas: 1 . aos aspectos éticos, técnicos e materiais do trabalho do assistente social no INSS; 2. às competências e atribuições profissionais no órgão; 3. à autonomia profissional; 3. aos desvios de função. Essa ação comprometeu a autonomia da pesquisa, mas fizeram parte das entrevistas por serem elementos essenciais para uma análise qualificada desse estudo.

Reflexo do concurso público de 2009, o perfil das assistentes sociais entrevistadas revela uma nova identidade do Serviço Social previdenciário no Distrito Federal. Grande parte das entrevistadas, $80 \%$, ainda se encontra em estágio probatório em seus postos de trabalho e são recém-formadas, o que ainda causa certa imprecisão quanto ao objetivo fundamental do seu trabalho, o conhecimento do que é "deficiência" no contexto capitalista e, em alguns momentos, dúvidas e incertezas no cotidiano profissional quando estão de frente com a pessoa com deficiência. Muitas dessas dúvidas e incertezas ocorrem, essencialmente, por uma falta de orientação das competências e atribuições do cargo de Analista do Seguro Social com formação em Serviço Social para além dos caracteres expressos ainda no edital do concurso realizado em 2009.

O processo de trabalho do assistente social na avaliação social está repleto de desafios colocados à categoria profissional conforme alerta Cartaxo (2010): 1. discussão com um novo olhar na forma de avaliação da incapacidade para o trabalho baseada na CIF; 2. rigoroso trato teórico-metodológico para apreensão crítica da realidade social; 3. constante pesquisa como fundamento do exercício profissional em seus programas e projetos - numa relação dialética entre a teoria- prática profissional; 4. permanente capacitação profissional qualificada às demandas dos usuários $e$ as requisições institucionais de acordo com o Código de Ética da profissão; 5. reafirmação da Matriz Teórico-Metodológica do Serviço Social; 8. articulação da política previdenciária com a 
saúde e assistência social.

Moreira (2010) também coloca alguns desafios a serem problematizados e superados entre os assistentes sociais que realizam a avaliação social: 1. defesa da ampliação da renda per capita dos membros da família do requerente considerado no cálculo da renda familiar; 2. realizar estudos e pesquisas sobre os resultados alcançados com a adoção do novo modelo; 3 . intensificar o debate junto à sociedades sobre o novo modelo; 4. identificar necessidades e demandas e propor soluções de aperfeiçoamento do instrumento; 5. agilizar a implementação das ações necessárias ao aperfeiçoamento do instrumento e da avaliação; 8. ampliação o acompanhamento dos beneficiários do BPC na rede de serviços socioassistenciais.

Em meio a tantos desafios apontados por Moreira (2010) e Cartaxo (2010), vamos focar, nesse estudo, aqueles que se apresentam com maior regularidade entre as assistentes sociais pesquisadas e os pontos mais polêmicos apresentados à categoria após um ano de implantação da avaliação social.

\subsection{Competências e Atribuições do Assistente Social no INSS}

A realização de concurso público, pelo INSS, para contratação de assistentes sociais, foi um marco histórico para a categoria. No entanto, o cenário que se configurou após a nomeação dos profissionais é conflituoso devido ao entendimento equivocado, por alguns gestores do INSS, que insistem em determinar aos profissionais a realização de atividades estranhas às competências do Serviço Social do INSS, nos termos da Lei 8.213/1991, e às competências e atribuições desses profissionais previstas na Lei que regulamenta a profissão - Lei 8.662/1993, assim como as atividades estabelecidas no Edital do concurso de 2009 (CFESS, 2010; 2010a).

O Parecer Jurídico CFESS 12, de 2010, informa que o documento OS IAPAS - SAD no. 135, de 04/03/1986, que trata das atribuições dos assistentes sociais no INSS se encontra desatualizado e já não atende às novas demandas institucionais. Em função do intervalo de tempo decorrido e das alterações na estrutura organizacional do INSS, os assistentes sociais procuraram adequar suas atividades às demandas apresentadas pelos usuários.

O trabalho desenvolvido pelos assistentes sociais do Serviço Social no INSS tem respaldo na Lei no. 8.213/1991, artigo 88, e no Decreto ํㅜ. 3.048/1999, artigo 161, que divergem daqueles elencados no documento de 1986.

A Lei 10.855/2004, após alteração pela MP 359/2004, convertida na Lei 11.501, de 2007, possibilita a regulamentação das atribuições de Analistas do Seguro Social, com 
atribuições específicas, conforme especificados nos seguintes artigos:

Art. $5^{0}$. A. Os cargos de provimento efetivo de nível superior de analista Previdenciário, integrantes da Carreira do Seguro Social, do Quadro de Pessoal do INSS, mantidas as atribuições gerais, passam a denominar-se Analista do Seguro Social (BRASIL, 2007e).

O cenário de incerteza sobre competências e atribuições ainda presente no cargo de Analista em Seguro Social com formação em Serviço Social tem ampla contribuição na própria relação das assistentes sociais com os gerentes das Agências da Previdência Social.

Antes, não tinha analista nas agências da previdência, nós somos as primeiras e isso provocou certa instabilidade na relação profissional. Avalio que os gerentes ficaram em alerta na possibilidade de perderem seus cargos (entrevistada 5).

Inicialmente, tive dificuldade no trabalho principalmente com o gerente da agência. Temos visões sobre determinadas coisas diferentes. O gerente não sabe o que é o trabalho do assistente social no INSS e isso implica em dizer que temos que a todo o momento reafirmar o nosso papel aqui (entrevistada 2).

Muito embora a publicação do ato normativo possa ser um instrumento capaz de resolver parte desses problemas, a espera pelo documento não é tão tranquila para todas as assistentes sociais do INSS do Distrito Federal.

Sinceramente, não sei o que esperar desse ato normativo. Tenho medo dos desdobramentos e do que virá escrito nele (entrevistada 4).

Existe um discurso hegemônico de que a publicação deste ato normativo é urgente para um respaldo e objetividade do trabalho do assistente social. Os relatos a seguir trazem uma reflexão sobre ausência de um termo jurídico que aponte as competências profissionais no INSS:

\begin{abstract}
A falta do ato normativo do INSS sobre as atribuições profissionais do cargo de Analista do Seguro Social com formação em Serviço Social pode ser uma brecha para que ocorram desvios de função. Só tenho o edital do concurso para questionar sobre minhas atribuições profissionais aqui, além da Lei de Regulamentação. Embora exista o entendimento de que a habilitação do BPC seja competência do Técnico do Seguro Social, o ato normativo viria a responder a todos que isso não é competência do Serviço Social (entrevistada 2).
\end{abstract}

O ato normativo ajudaria e protegeria o profissional. Por exemplo, aqui não tenho apoio administrativo. Isso faz com que eu tenha que protocolar processos, solicitar transporte para visitas, telefonar para o usuário para remarcar o processo. Nunca habilitei benefício, mas existe um discurso de colocar qualquer coisa para 0 assistente social fazer: se colar, se topar, ótimo (entrevistada 3). 
da Previdência Social sobre a orientação no trabalho do assistente social no INSS. Exemplo de determinações equivocadas, destacamos o memorando 72/2009 de Gerência Executiva do INSS em Juazeiro/BA, de 29/12/2009, e o memorando circular 02/INSS da Gerência Executiva do INSS em Petrolina/PE, de 19/10/2009, determinando a realização de habilitação de benefícios pelos assistentes sociais. Nessa tensa relação entre o gerente da agência e o assistente social, foram realizadas ameaças por alguns gestores nas quais registram que o não acatamento das ações determinadas por eles gerará avaliações negativas nos estágios probatórios destes profissionais, na avaliação de desempenho e em denúncias aos órgãos de corregedoria do INSS (CFESS, 2010; 2010a).

Toda a normatização que regulamenta a ação do Serviço Social na instituição, bem como as diretrizes teórico-metodológicas, bem diferente de habilitar benefícios, determinam que as ações do Serviço Social tenham como focos principais a socialização de informações previdenciárias, o fortalecimento do coletivo e a assessoria às organizações públicas e privadas em matéria de previdência social, com intuito de contribuir para o melhor acesso do trabalhador aos direitos previdenciários (INSS, 1994).

lamamoto (2005) nos lembra que o Serviço Social é regido por normas próprias, ou seja, qualquer alteração no que se refere às suas competências e atribuições privativas deve estar de acordo com a regulamentação vigente e submeter-se a discussão da categoria profissional nos seus mecanismos representativos, CRESS e CFESS. Sobre competências e atribuições privativas do assistente social, a Lei 8.662/1993 determina que:

Art. 4ํㅡㄴ Constituem competências do Assistente Social:

I - elaborar, implementar, executar e avaliar políticas sociais junto a órgãos da administração pública, direta ou indireta, empresas, entidades e organizações populares;

II - elaborar, coordenar, executar e avaliar planos, programas e projetos que sejam do âmbito de atuação do Serviço Social com participação da sociedade civil;

III - encaminhar providências, e prestar orientação social a indivíduos, grupos e à população;

IV - (Vetado);

V - orientar indivíduos e grupos de diferentes segmentos sociais no sentido de identificar recursos e de fazer uso dos mesmos no atendimento e na defesa de seus direitos;

VI - planejar, organizar e administrar benefícios e Serviços Sociais;

VII - planejar, executar e avaliar pesquisas que possam contribuir para a análise da realidade social e para subsidiar ações profissionais;

VIII - prestar assessoria e consultoria a órgãos da administração pública direta e indireta, empresas privadas e outras entidades, com relação às matérias relacionadas no inciso II deste artigo;

IX - prestar assessoria e apoio aos movimentos sociais em matéria relacionada às políticas sociais, no exercício e na defesa dos direitos civis, políticos e sociais da coletividade;

$X$ - planejamento, organização e administração de Serviços Sociais e de Unidade de Serviço Social;

XI - realizar estudos sócio-econômicos com os usuários para fins de benefícios e serviços sociais junto a órgãos da administração pública direta e indireta, empresas privadas e outras entidades. 
Art. 5 Constituem atribuições privativas do Assistente Social:

I - coordenar, elaborar, executar, supervisionar e avaliar estudos, pesquisas, planos, programas e projetos na área de Serviço Social;

II - planejar, organizar e administrar programas e projetos em Unidade de Serviço Social;

III - assessoria e consultoria e órgãos da Administração Pública direta e indireta, empresas privadas e outras entidades, em matéria de Serviço Social;

IV - realizar vistorias, perícias técnicas, laudos periciais, informações e pareceres sobre a matéria de Serviço Social;

V - assumir, no magistério de Serviço Social tanto a nível de graduação como pós graduação, disciplinas e funções que exijam conhecimentos próprios e adquiridos em curso de formação regular;

VI - treinamento, avaliação e supervisão direta de estagiários de Serviço Social;

VII - dirigir e coordenar Unidades de Ensino e Cursos de Serviço Social, de graduação e pós-graduação;

VIII - dirigir e coordenar associações, núcleos, centros de estudo e de pesquisa em Serviço Social;

IX - elaborar provas, presidir e compor bancas de exames e comissões julgadoras de concursos ou outras formas de seleção para Assistentes Sociais, ou onde sejam aferidos conhecimentos inerentes ao Serviço Social;

$X$ - coordenar seminários, encontros, congressos e eventos assemelhados sobre assuntos de Serviço Social;

XI - fiscalizar o exercício profissional através dos Conselhos Federal e Regionais;

XII - dirigir serviços técnicos de Serviço Social em entidades públicas ou privadas;

XIII - ocupar cargos e funções de direção e fiscalização da gestão financeira em órgãos e entidades representativas da categoria profissional (BRASIL, 1993).

Diante disso, pode-se afirmar que a realização de habilitação de benefícios é uma prática contraditória às competências e atribuições privativas do profissional de Serviço Social, da mesma forma que, forçar os assistentes sociais a tal prática se torna uma ilegalidade, ferindo toda a legislação que regulamenta a atuação profissional no INSS, o Código de Ética Profissional (1993) e a Lei que regulamenta a profissão (8.662/1993).

Em relação ao BPC, o assistente social atua na realização da avaliação da deficiência e do grau de incapacidade das pessoas com deficiência que buscam o BPC, juntamente com a perícia médica, conforme determina o Decreto 6.214/2007. Além disso, realiza ações de socialização das informações junto aos usuários e à sociedade civil, por meio de abordagens individuais e grupais viabilizando articulações com instituições e os poderes públicos.

Sobre a descrição do cargo de Analista do Seguro Social com formação em Serviço Social, o Edital 1/2008 é bastante claro na descrição do que chama de "atividades" do cargo:

\section{DO CARGO}

2.1. Analista do Seguro Social com formação em Serviço Social

2.1.1. Descrição das atividades: Prestar atendimento e acompanhamento aos usuários dos serviços prestados pelo INSS e aos seus servidores, aposentados e pensionistas; elaborar, executar, avaliar planos, programas e projetos na área de Serviço Social e Reabilitação Profissional; realizar avaliação social quanto ao acesso aos direitos previdenciários e assistenciais; promover estudos sócio-econômicos visando a emissão de parecer social para subsidiar o reconhecimento e a manutenção de direitos previdenciários, bem como a decisão médico-pericial; e executar de conformidade com a sua área de formação as demais atividades de competência do INSS (CFESS, 2010). 
Tendo como referência o constante no item 2 do Edital 1/2008, não há dúvida de que as atividades ali previstas, majoritariamente, são atribuições privativas dos assistentes sociais, conforme estabelece a Lei 8.662/1993, que regulamenta a profissão de assistente social, tais como:

elaborar, executar, avaliar planos, programas e projetos na área de Serviço Social; realizar avaliação social quanto ao acesso aos direitos previdenciários e assistenciais; promover estudos sócio-econômicos visando à emissão de parecer social para subsidiar o reconhecimento e a manutenção de direitos previdenciários, bem como a decisão médico-pericial (BRASIL, 1993, Art. 5‥).

Acrescente-se, ainda, de acordo com o Parecer Jurídico CFESS 12/10, que no mesmo item consta a exigência da formação em Serviço Social para o cargo de Analista de Seguro Social, ou seja, somente profissionais com formação em Serviço Social, portanto assistentes sociais, estavam aptos à inscrição no certame, apresentando o diploma respectivo. De acordo com a Lei 8.662/1993, para o exercício regular da profissão de assistente social, além da apresentação do diploma do curso de Serviço Social regularmente reconhecido pelo Ministério da Educação (MEC), é obrigatória a inscrição no CRESS da respectiva jurisdição onde se dará a atuação profissional.

\footnotetext{
Art. $1^{0}$. O exercício da profissão de assistente social requer prévio registro nos Conselhos Regionais de Serviço Social, que tenham jurisdição sobre a área de atuação do interessado, nos termos do parágrafo único do artigo $1^{\circ}$ da Lei $\mathrm{n}^{\circ}$ 8662/93.
}

Art. $3^{0}$. A designação profissional de "assistente social" é privativa dos inscritos nos Conselhos Regionais de Serviço Social/CRESS, estando obrigado ao registro ou a permanência deste perante os CRESS, inclusive aqueles que estejam em desvio de função, mas que tenham cargo, registro ou contrato sob esta denominação.

Art. $6^{0}$. É prerrogativa do assistente social e de qualquer trabalhador, independentemente da denominação de seu cargo ou função, exercer somente as funções pertinentes ao cargo que ocupa ou que foi investido ou contratado (CFESS, 2010).

Esclarecemos que a não obediência a essas exigências legais caracteriza exercício ilegal da profissão (CFESS, 2010).

Por fim, o edital prevê que aquele que for empossado no cargo em questão, deve executar, em conformidade com a sua área de formação, as demais atividades de competência do INSS. Neste aspecto, fica evidente que as demais atividades executadas deverão ser na área de formação de Serviço Social. Portanto, só pode ser exigido que o assistente social, analista de seguro do INSS, exerça atribuições compatíveis a sua formação profissional e de acordo com a Lei de Regulamentação da profissão de assistente social de 1993 (CFESS, 2010). 


\subsection{Aspectos Materiais, Técnicos e Éticos no Exercício Profissional}

Tratar dos aspectos materiais, técnicos e éticos no trabalho do assistente social é também tomar conhecimento dos elementos para uma análise do trabalho do assistente social em tempo do capital fetiche, que considere suas particularidades e focalize as tensas relações entre projeto ético-político profissional e estatuto assalariado (IAMAMOTO, 2008).

O dilema condensado na inter-relação entre projeto profissional e estatuto assalariado significa afirmar a relativa autonomia do assistente social na condução de suas ações profissionais, socialmente legitimada pela formação acadêmica de nível universitário e pelo aparato legal e organizativo que regulam o exercício de uma "profissão liberal" na sociedade. A autonomia é condicionada pelas lutas hegemônicas presentes na sociedade que alargam ou retraem as bases sociais que sustentam a direção social projetada pelo assistente social ao seu exercício, permeada por interesses de classes e grupos sociais, que incidem nas condições que circunscrevem o trabalho voltado ao atendimento de necessidades de segmentos majoritários da classe trabalhadora (IAMAMOTO, 2008).

Embora regulamentado como uma profissão liberal na sociedade, lamamoto (2008) defende que o Serviço Social não se realiza como tal. Isso significa que o assistente social não detém todos os meios necessários para a efetivação de seu trabalho: financeiros, técnicos e humanos necessários ao exercício profissional autônomo. Parte dos meios ou recursos materiais, financeiros e organizacionais, necessários ao exercício desse trabalho, são fornecidos pelas entidades empregadoras. Portanto, a condição de trabalhador assalariado não só enquadra o assistente social na relação de compra e venda da força de trabalho, mas molda a sua inserção socioinstitucional na sociedade brasileira.

Falar em autonomia profissional no âmbito do INSS é delicado para algumas assistentes sociais que são subordinadas tecnicamente à Divisão de Serviço Social e administrativamente ao gerente da Agência da Previdência Social. O chefe próximo e direto das profissionais é o gerente da agência. O limite da autonomia profissional está na confusão estabelecida para saber quem é o profissional que irá marcar a avaliação social e ainda na confusão de alguns gestores em não conhecer o significado do trabalho do assistente social.

A autonomia profissional constitui um dos desafios contemporâneos postos ao assistente social, embora esta questão seja garantida como um dos seus direitos no artigo $2^{\circ}$ alínea "h" do Código de Ética de 1993: "[...] ampla autonomia no exercício da profissão, não sendo obrigado a prestar serviços profissionais incompatíveis com as suas atribuições, cargos ou funções" (CFESS, 1993, p. 13).

Uma das condições do exercício democrático é captar os reais interesses e 
necessidades da classe trabalhadora, conhecer suas demandas para que se possa efetuar a crítica do senso comum da herança intelectual acumulada (IAMAMOTO, 2008).

O Código de Ética do Assistente Social (1993) nos indica um rumo ético-político, um horizonte para o exercício profissional. O desafio é a materialização dos princípios éticos na cotidianidade do trabalho, evitando que se transformem em indicativos abstratos, descolados do processo social.

Um importante desafio ético colocado às assistentes sociais do INSS é o sigilo profissional. Elemento imprescindível na relação com a pessoa com a deficiência no momento da avaliação social, alguns problemas foram encontrados na efetivação daquilo que trata o capítulo V (do Sigilo Profissional) do Código de Ética de 1993.

\begin{abstract}
Quando cheguei aqui não tinha sala do Serviço Social. Ao questionar com o gerente da agência, encontrei a resposta que o atendimento seria no balcão, um lugar aberto, de frente para dezenas de cadeiras com pessoas esperando pelo atendimento. Já nessa primeira reunião, informei que o atendimento do Serviço Social não poderia ser feito dessa maneira, era necessário uma sala específica para garantir o sigilo profissional (entrevistada 5).
\end{abstract}

Uma conversa nesse tom que estamos tendo, não é possível pessoas que estejam aqui fora, esperando pelo atendimento, ouçam. Mas, por exemplo, nesse momento, conseguimos ouvir o que a funcionária aqui do lado conversa com outra pessoa. Acredito que, nessa sala, não exista um sigilo profissional absoluto (entrevistada 3).

O atendimento efetuado pelo assistente social deve ser feito a portas fechadas, de forma a garantir o sigilo (CFESS, 2006). No entanto, só isso por si não garante o sigilo profissional. As salas das entrevistadas acima eram delimitadas por meio de divisórias que realmente não possuem um eficiente isolamento acústico, o que, mesmo de portas fechadas, torna difícil, em alguns momentos, seguir o que é preconizado pelo Código de Ética de 1993 ao afirmar que constitui direito do assistente social manter o sigilo profissional e que tal sigilo protegerá o usuário em tudo aquilo de que o assistente social tome conhecimento, como decorrência do exercício da atividade profissional (CFESS, 1993).

Outro importante instrumento que merece destaque nesse item, a Resolução CFESS $n^{0}$. 493, de 21 de agosto de 2006, dispõe sobre as condições éticas e técnicas do exercício profissional do assistente social. $\mathrm{Na}$ intenção de deixar claro como deve ser a realidade profissional do assistente social no espaço sócio-institucional, a Resolução de 2006 apresenta logo no primeiro artigo:

É condição essencial, portanto obrigatória, para a realização e execução de qualquer atendimento ao usuário do Serviço Social a existência de espaço físico, nas condições que esta Resolução estabelecer (CFESS, 2006, Art. 1‥).

Em algumas Agências da Previdência Social, encontramos um cenário, em termos materiais, que vão de encontro à Resolução CFESS 493/2006, ao afirmar que o local de 
atendimento destinado ao assistente social deve ser dotado de espaço suficiente para abordagens individuais ou coletivas, conforme as características dos serviços prestados, e deve possuir e garantir as seguintes características físicas: 1. iluminação adequada ao trabalho diurno e noturno, conforme a organização institucional; 2. recursos que garantam a privacidade do usuário naquilo que for revelado durante o processo de intervenção profissional; 3. ventilação adequada a atendimentos breves ou demorados e com portas fechadas; 4. espaço adequado para colocação de arquivos para a adequada guarda de material técnico de caráter reservado (CFESS, 2006).

A questão da iluminação das salas das assistentes sociais foi considerada boa para todas as profissionais entrevistadas. Já a questão da ventilação e do espaço foi ponto em destaque na falas das assistentes sociais.

A estrutura física aqui é muito ruim. Essa sala é muito pequena e totalmente fechada, sem janela. Já tivemos casos aqui de usuários passarem mal. Claramente, não houve uma preparação da agência para me receber, um profissional que executa parte de uma ação obrigatória para acesso das pessoas deficientes ao BPC (entrevistada 2).

Outro problema apresentado pelas entrevistadas é sobre a condição do material necessário na operacionalização do trabalho e a segurança do arquivo material técnico na Agência da Previdência Social.

\begin{abstract}
Mesmo já reclamando algumas vezes com o gerente da agência, ainda temos mesa caindo aos pedaços, gaveta quebrada, porta da sala que não tem chave, o que provoca falta de segurança em relação aos processos, [...] a impressora é lenta, o computador defasado. A modernidade do INSS tem um limite, somente está onde a mídia chega. Quando vejo reportagens pela televisão, vejo computadores modernos, mesas em bom estado. Isso não ocorre no Serviço Social, talvez por um pensamento conservador que até hoje coloca que o Serviço Social não é prioridade, é algo complementar e também, talvez, por eu ser uma servidora nova no órgão. Em termos materiais, é uma modernização que ainda não chegou por aqui (entrevistada $3)$.
\end{abstract}

Essa realidade revela certo descaso ao trabalho do assistente social no INSS, ainda carregado do ranço conservador histórico do caráter complementar, não essencial, do trabalho do assistente social no INSS (SILVA, 2008). Já sabíamos, e a Resolução CFESS 493/2006 tornou escrito, o material técnico utilizado e produzido no atendimento é de caráter reservado, sendo seu uso e acesso restrito aos assistentes sociais (CFESS, 2006), o que não ocorre em algumas agências no Distrito Federal.

O assistente social deve informar por escrito à entidade, instituição ou órgão que trabalha ou presta serviços, sob qualquer modalidade, acerca das inadequações constatadas por este, quanto às condições éticas, físicas e técnicas do exercício profissional, sugerindo alternativas para melhoria dos serviços prestados (CFESS, 2006). Os problemas relatados aqui já foram levados ao setor competente pelas profissionais que 
ainda tentam resolver esses problemas por meios administrativos.

Os aspectos materiais, éticos e técnicos do trabalho profissional, em comparação aos outros aspectos que procuramos conhecer, foram relatados com mais propriedade e angústia pelas assistentes sociais. Elas apresentaram um cenário complexo e com muitos desafios ainda a serem superados no exercício profissional, o que contribuiu para entendermos a fragilidade e dificuldades do trabalho do assistente social no INSS mesmo após um ano do concurso nacional em que centenas de profissionais foram aprovadas, classificadas e se encontram em exercício.

No item a seguir, iremos tratar sobre alguns elementos que as profissionais relataram como os mais difíceis no momento da avaliação social, bem como estabelecer um diálogo crítico com os critérios de elegibilidade do BPC a partir das entrevistas.

\subsection{A Deficiência, os Critérios de Elegibilidade e a Avaliação Social}

A exigência da pobreza familiar como critério de acesso ao BPC transforma o benefício em uma garantia de renda destinada à família e não somente à pessoa com deficiência. $O$ critério de $1 / 4$ de salário mínimo per capita familiar de renda que permite 0 acesso ao BPC aliado à pobreza das famílias das pessoas com deficiência configuram o alcance do benefício como restrito para promover mudanças significativas nos padrões de consumo das pessoas com deficiências atendidas (SPOSATI, 2008; GOMES, 2008).

Fato considerado motivo de estigma no BPC pelas entrevistadas é a comprovação por parte dos usuários dos critérios restritos de elegibilidade (SPOSATI, 2008). Em resposta a isso, as profissionais entrevistadas apresentaram alguns pontos a serem superados quanto aos critérios de elegibilidade do benefício. Os critérios restritivos do BPC que devem ser superados, apontados pelas assistentes sociais, e que se caracterizam também como desafios são:

1. a renda familiar per capita de $1 / 4$ de salário mínimo tem de ser alterada para, pelo menos meio salário mínimo, com o objetivo de expandir o BPC a um número maior de pessoas;

2. a necessidade de uma melhor compreensão do que seja deficiência e luta para que as doenças crônicas sejam entendidas como incapacitantes para o trabalho;

3. a redução da idade para 60 anos na condição de acesso ao benefício para idosos, o que estará de acordo com a idade mínima que caracteriza alguém como pessoa idosa estipulada pela Organização Mundial de Saúde (OMS) e pelo Estatuto do Idoso (2003);

4. a não inclusão do benefício como cálculo da renda per capita no caso de uma segunda pessoa com deficiência na família conforme já ocorre com os idosos. 
Em relação a prática da atividade da avaliação social, os domínios vida doméstica, relação e interações pessoais, áreas principais da vida, e vida comunitária, social e cívica, referentes ao componente Atividade e Participação, são os mais difíceis de serem avaliados de acordo com as profissionais entrevistadas.

Unanimidade apresentada pelas assistentes sociais foi a dificuldade em avaliar crianças de até quatro anos com o novo instrumento. Um questionamento colocado pelas profissionais foi

como avaliar uma criança de um ano se ela tem problema para se relacionar? (entrevistada 3).

Assim, como a questão anterior, algumas assistentes sociais relataram que algumas questões do instrumento não deveriam ser perguntadas para crianças como "tem problema para se relacionar com os outros?" ou "mantém relações sociais, interagindo com afeto e respeito nos relacionamentos?". Outras profissionais consideram desnecessário crianças com deficiência passarem por avaliação social.

Por muitas vezes, parece não fazer sentido realizar avaliação social com crianças. É bem difícil e me parece algo descabido (entrevistada 5).

A falta de certa objetividade do instrumento é capaz de gerar entendimentos diferenciados sobre uma mesma questão. Não existe visão única acerca da aplicação do instrumento. Uma assistente social relatou que, no momento de um recurso de processo, avaliou bem diferente uma mesma pessoa com deficiência, antes avaliada por outra colega.

Acerca da objetividade de todo o processo necessário para acesso ao BPC, reafirmamos o posicionamento de Diniz et. al (2007), quando informa que as maiores chances de objetividade no acesso ao BPC está condicionada a uma maior padronização no momento da avaliação para saber qual pessoa com deficiência tem direito ao benefício.

As dúvidas, por meio das entrevistas, sobre a uniformidade no entendimento de todas as questões presentes na avaliação social revelam um caráter difuso dos critérios ainda não padronizados para dizer quem é elegível ao BPC. Segundo Diniz et. al (2007), isso ainda revela a concessão do benefício vinculada à interpretação individual profissional sobre quais devem ser as deficiências atendidas pelo BPC.

As questões "tem problema em brincar sozinho ou com os outros?", "tem problema em participar da educação pré-escolar?" e "tem problema em realizar as atividades e cumprir as responsabilidades relacionadas à escola?" e "coopera com os demais alunos?" são exemplos da chamada "Áreas Principais da Vida" que se referem à realização das tarefas e ações necessárias para participar das atividades de educação e das transações econômicas. Essas são questões que as assistentes sociais devem fazer para crianças de 
dois anos por exemplo.

Como devo avaliar isso? É no campo real, no imaginativo? E se a criança não tiver na escola? O que é ter problema em participar da educação pré-escolar? Temos de imaginar o que seria essas coisas para realizar a avaliação (entrevistada 3).

Todas as assistentes sociais afirmaram que a avaliação é importante instrumento quando se fala em BPC para pessoas com deficiência. Ao reconhecer a importância de se avaliar fatores ambientais e participação social, é estabelecida tanto uma exigência presente no decreto 6.214/2007 quanto se ultrapassa um entendimento da deficiência além do corpo e do biológico, sendo possível compreender e avaliar a relação social estabelecida da pessoa com deficiência e o mundo em que ela vive, o que aproxima o BPC à CIF e ao "modelo social de deficiência" que questionou o saber puramente biomédico no entendimento da deficiência.

Embora ainda exista certa imprecisão conceitual no que seria deficiência por parte das assistentes sociais no INSS, é possível identificar falas que revelam o entendimento de que a deficiência não pode ser identificada apenas por atributos corporais dos indivíduos, devendo ser entendida como resultado da interação dos atributos corporais, atributos socioeconômicos e o meio em que vive a pessoa.

O "modelo social da deficiência", que parece ser o defendido entre as entrevistadas, representa um avanço no debate sobre a deficiência em nível mundial, evidencia a necessidade de problematizar a relação de um corpo com lesão com as estruturas sociais existentes, sendo necessária uma relação com a política, a economia e o social (DINIZ, 2007).

As entrevistadas apontaram que a avaliação social é parte de um processo capaz de transformar vidas por meio da transferência de um salário mínimo. Muito embora um valor bem limitado, o benefício é capaz de contribuir para uma melhoria relativa do beneficiário, sendo o valor, por exemplo, capaz de promover o pagamento de um aluguel, melhorar a condição alimentar.

As assistentes sociais também relataram que a avaliação social tem o poder de promover a ampliação do acesso ao BPC para pessoas com deficiência, embora ainda acreditem que a perícia médica tenha um poder decisório. Segundo as entrevistadas, a avaliação social pode resolver um caso de uma deficiência moderada que antes do novo instrumento de avaliação social era praticamente impossível de se conseguir. Já os casos de deficiência leve, segundo as entrevistadas, é bem difícil conseguir.

Colocar o potencial da avaliação social capaz de definir o acesso ao BPC de uma pessoa com deficiência moderada vai além da análise de Diniz et. al (2007, p. 2.589, grifo nosso) ao colocar, em um momento em que ainda não se realizava a avaliação social, que 
"as transferências monetárias do BPC são concedidas a pessoas idosas ou pessoas com deficiência grave, cuja renda familiar per capita seja inferior a um quarto de salário mínimo".

Segundo relato das entrevistadas, parece existir certa subordinação da avaliação social à perícia médica. O grau da deficiência parece ainda ser um elemento essencial no acesso ao BPC. No entanto, com a introdução do novo instrumento, ampliou-se o benefício, foi possível ir além do acesso ao benefício apenas aquelas pessoas com deficiência que tinham deficiência grave.

Há uma clareza por parte das profissionais de que o BPC para pessoas com deficiência é um direito que está sendo garantido devido à incapacidade para o trabalho e para a vida independente. A concessão do benefício é a efetivação de um direito social.

Reafirmar o BPC como um direito é importante em um momento em que parece existir uma crise na efetivação de direitos na nossa sociedade capitalista, (re)afirmar o BPC como direito ainda é um desafio colocado às profissionais. A fala das assistentes encontram respaldo teórico na literatura crítica do Serviço Social que "o balanço do caminho percorrido pela introdução do BPC exige um conjunto de reflexões que permitam consagrá-lo como política de direito à proteção social não contributiva" (SPOSATI, 2008, p. 125).

$\mathrm{Na}$ intenção de qualificar, entender melhor e sanar dúvidas sobre a avaliação social, as profissionais entrevistadas consideram importante a construção de uma política de participação em cursos de treinamento e especialização sobre temas relacionados tanto, exclusivamente, ao instrumento de avaliação social, quanto aos programas, projetos, serviços e benefícios sociais. Todas relataram que realizaram um curso de capacitação para a prática profissional antes de entrarem em exercício. Avaliaram o curso como quase perfeito, afirmando que seria necessário um maior tempo para discussão do instrumento de avaliação social e estudos de caso. As assistentes sociais reportaram a importância da capacitação continuada para trocar experiências, compartilhar e solucionar dúvidas sobre o instrumento na intenção de alcançar uma maior uniformidade da avaliação em todo o Distrito Federal.

Sobre a capacitação continuada no Serviço Social, Mota (2003) realiza uma defesa como necessidade latente que contribui para uma direção social coerente com o projeto ético-político profissional. Entretanto, conforme lamamoto (2008), o conjunto de princípios e valores que norteiam o exercício profissional, que têm relação estreita com a perspectiva ídeo-política e com as escolhas de cada assistente social, também são pautadas na visão de mundo dos sujeitos profissionais.

Por fim, a avaliação social realizada pelas assistentes sociais do INSS para o acesso ao BPC contribui para ampliar o acesso ao benefício e superar as concepções restritas de deficiência e de incapacidade para o trabalho e vida independente. Isso implica em ir além 
do saber biomédico que decidia qual pessoa com deficiência tinha direito ao benefício. Esse estudo se mostrou importante por revelar que a implantação da avaliação social representa também a existência de algumas tensões no momento da avaliação no sentido da compreensão de algumas questões do instrumento, falta de uniformidade entre as pesquisadas sobre o entendimento de outras questões e apontamentos de alguns problemas no momento da operacionalização do BPC. 


\section{CONSIDERAÇÕES FINAIS}

O debate acerca da deficiência passou muitos séculos construído a partir de um discurso místico. Antes considerada uma expressão do azar, a deficiência ganha um novo status por meio da narrativa biomédica do século XIX em que o principal objetivo era normalizar o corpo com lesão, ajustar o corpo com deficiência a partir de um julgamento moral estético. A partir de 1970, a deficiência sai da exclusividade do discurso biomédico. modelo médico de deficiência passa a ser questionado, a deficiência não é mais uma simples expressão de uma lesão que impõe restrições à participação social de uma pessoa. Deficiência é um conceito complexo que reconhece o corpo com lesão, mas que também denuncia a estrutura social que oprime a pessoa com deficiência (DINIZ, 2007).

A valorização do corpo considerado perfeito para produzir ao gosto capitalista é comparado ao corpo com lesão. As estruturas sociais vigentes discriminam o corpo com alguma restrição e promovem a exclusão ao mercado de trabalho milhões de pessoas com deficiência. As diversas expressões da deficiência exigem do Estado ações e instrumentos legais que permitam a proteção social às pessoas com deficiência. A deficiência é um produto da sociedade capitalista e constitui um problema do Estado e da sociedade, sendo necessária a introdução de instrumentos que promovam equidade e justiça social. Precisamos reconhecer a deficiência como expressão da diversidade humana. A proteção social assume várias orientações por meio de diferentes políticas sociais. Nesse trabalho, foi escolhida a política de assistência social como urgente e privilegiada muito por conta da importância e abrangência do BPC como uma resposta às desvantagens sociais em que se encontra as pessoas com deficiência e como resposta para reduzir a pobreza extrema no Brasil.

O BPC é o único benefício não contributivo do sistema de seguridade social brasileiro para pessoas com deficiência, objetivo da assistência social da CF/1988, benefício de destaque na LOAS/1993 e hoje regulamentado por meio dos Decretos 6.214/2007 e 6.564/2008. Não é letra morta, materializa-se como um importante e real instrumento de proteção social também para pessoas com deficiência.

Talvez os limites do benefício se encontrem nos rigorosos critérios de seletividade para o acesso e escassez nos estudos sobre o BPC que tratam da implementação, gerenciamento e expansão do seu alcance. A pesquisa que fundamentou esta monografia avaliou aspectos relativos à operacionalidade do BPC, variável com presença tímida entre os intelectuais da temática.

O Decreto 6.214/2007 incorporou as propostas feitas pela CIF que analisa a experiência da deficiência a partir de aspectos médicos e sociais, ou seja, a avaliação da 
deficiência e do grau de incapacidade será composta de avaliação médica e social. A avaliação médica da deficiência e do grau de incapacidade considerará as deficiências nas funções e nas estruturas do corpo, e a avaliação social considerará os fatores ambientais, sociais e pessoais, e ambas considerarão a limitação do desempenho de atividades e a restrição da participação social, segundo suas especificidades. As avaliações médica e social serão realizadas, respectivamente, pela perícia médica e pelo serviço social do INSS, por meio de instrumentos desenvolvidos especificamente para este fim (BRASIL, 2007).

Para atender a uma ampla demanda do BPC em relação à avaliação social, uma exigência do Decreto 6.214/2007, o órgão responsável pela operacionalização do benefício, - INSS, após mais de vinte anos sem concurso para assistentes sociais e ampla luta do CFESS e da sociedade, liberou o Edital para o concurso para Analista do Seguro Social com formação em Serviço Social em novembro de 2008 com a prova em janeiro de 2009.

Em resposta à pergunta que norteou esse estudo - quais os desafios do processo da avaliação social tendo em vista as concepções restritivas da perícia médica sobre deficiência e grau de incapacidade? -, os achados da pesquisa mostram que os principais desafios a serem enfrentados pelas assistentes sociais nos processos relacionados são: 1 . construção e publicação das competências e atribuições profissionais em relação ao cargo que as profissionais ocupam - Analista do Seguro Social com formação em Serviço Social; 2. efetivação dos aspectos ético, material e técnico profissional de acordo com a Resolução CFESS 493/2006, bem como respeito a autonomia profissional; 3. a dificuldade em avaliar crianças em relação ao componente Atividade e Participação com o instrumento vigente.

Esses desafios revelam a dificuldades das condições para o exercício profissional do assistente social no âmbito do INSS, um órgão público em que o contrato de trabalho é estabelecido pelo considerado melhor meio jurídico do mercado de trabalho hoje que é o Regime Jurídico dos Servidores Públicos Civis da União, das Autarquias e das Fundações Públicas Federais, mediante a Lei $n^{0}$. 8.112/1990. Talvez essa fragilidade encontre resposta no pouco tempo, um ano, de exercício profissional no órgão.

As tendências da profissão, em relação ao exercício profissional, estão articuladas: 1) à realidade objetiva, ou seja, às condições éticas, materiais e técnicas de trabalho e ao conjunto de exigências e demandas (im)postas pelo empregador; b) à capacidade das assistentes sociais de decodificar criticamente as estrutura sociais vigentes e propor iniciativas que se contraponham ao processo atual de exploração e dominação burguesas; e c) às possibilidades de organização e participação política coletiva dos profissionais (DUARTE, 2007). As assistentes sociais que realizam a avaliação social no Distrito Federal encontram grandes problemas, principalmente, em relação ao item 1 apontado por Duarte (2007). 
A literatura do Serviço Social informa que parece existir uma crise de identidade na profissão também devido às novas competências e atribuições apresentadas na contemporaneidade (MARTINELLI, 2000). A inserção das profissionais de Serviço Social nas Agências da Previdência Social estudadas é pautada por limites e desafios em relação às exigências profissionais e à autonomia. Muito embora algumas realidades diferenciadas, esses desafios aparecem muito claros nos discursos das assistentes sociais. É certo que os maiores desafios estão ligados ao exercício profissional, em assegurar os direitos do assistente social em relação à Lei de Regulamentação da Profissão de Assistente Social (1993), ao Código de Ética do Assistente Social (1993) e à Resolução CFESS 493/2006.

Provável perda de identidade profissional no âmbito do INSS, que poderia revelar prejuízos tanto no poder de luta quanto no reconhecimento e fortalecimento da profissão na atualidade, não encontra fundamentação empírica nesse estudo. Muito embora exista certa fragilidade em termos de identidade profissional por conta da confusão entre cargo (Analista do Seguro Social com formação em Serviço Social) e profissão (assistente social), todas fizeram questão de demonstrar que a Lei 8.662/1993, importante instrumento jurídico do assistente social, é importante para assegurar as competências e atribuições do assistente social no órgão, já que o descaso em relação à divulgação do ato normativo sobre tais competências e atribuições na instituição é algo genuíno. Também podemos chegar a uma conclusão de que existe forte engajamento em busca de solução para os problemas dos assistentes sociais no âmbito do INSS por meio de algumas reuniões para tratar do trabalho do assistente social no INSS inclusive no XIII Congresso Brasileiro de Assistentes Sociais que ocorreu em 2010.

Para além de uma dificuldade em avaliar crianças, principalmente, o questionamento na necessidade de avaliar algumas questões para crianças, e o desconforto ético no momento da avaliação quando os dados de renda não condizem com a realidade de algum solicitante ao benefício (atualizar ou não atualizar a renda?), o instrumento utilizado para realizar a avaliação social não foi motivo de críticas severas e sistematizadas pelas profissionais. No entanto, afirmaram acerca da necessidade imperiosa de construção de cursos na intenção de uniformizar o entendimento de algumas questões e sanar dúvidas que possam existir.

O caminho percorrido neste trabalho não encerra as reflexões e os debates sobre os desafios da avaliação social para acesso ao BPC para pessoas com deficiência. Isso porque a avaliação social é uma exigência nova e precisa de alguns ajustes e porque se considera que a realidade é uma totalidade sempre mais rica do que todas as determinações que se possam reconstruir, ou melhor, abstrair, sendo possível conhecê-la somente por aproximações sucessivas. Por isso, concluir esse TCC não significa finalizar análises e 
reflexões sobre o objeto de estudo. Espera-se ter contribuído com o debate sobre os desafios da avaliação social para acesso ao BPC, possibilitando elementos para novos estudos, questionamentos e aprofundamentos da temática que iluminem, não só o fazer profissional no INSS, mas que possibilitem a crítica qualificada e articulada aos processos sociais da atualidade. 


\section{REFERÊNCIAS BIBLIOGRÁFICAS}

ABBERLEY, Paul. The Concept of Opression and the Development of a Social Theory of Disability. In: BARTON, Len; OLIVER, Mike. Disability Studies: Past, Present and Future. Leeds: The Disability Press, 1987.

ABREU, Marina M.; LOPES, Josefa B. O Plano Básico de Ação do Serviço Social no INPS - 1972: racionalidade técnica modernizadora no serviço assistencial da política previdenciária. In: BRAGA; CABRAL (Org.). Serviço social na Previdência: trajetória, projetos profissionais e saberes. 3. ed. São Paulo: Cortez, 2008.

ACANDA, Jorge Luis. Política social, sociedad civil y crisis económica: retos del futuro. In: Revista SER Social, v. 1, n. 2. Brasília: SER Social UnB, 2010. pp. 13-30

AGUIAR, Antônio Geraldo de. Serviço Social e Filosofia: das origens a Araxá. São Paulo, Cortez, 1982.

ALBRECHT, G. L.; SEELMAN, K. D.; BURY, M. (Eds.). Handbook of Disability Studies. Thousand Oaks. Sage Publications. 2001.

BARBOSA, L.; DINIZ, D.; SANTOS, W. Diversidade corporal e perícia médica: novos contornos da deficiência para o Benefício de Prestação Continuada. Revista Textos e Contextos, v. 8, n. 2. Porto Alegre: PUCRS, 2009.

BARNES, C.; OLIVER, M.; BARTON, L. (Eds.). Disability Studies Today. Cambridge, UK: Polity Press in association with Blackwell Publishers. 2002.

BEHRING, Elaine Rossetti. Brasil em contra-reforma - desestruturação do Estado e perda de direitos. São Paulo: Cortez, 2003.

BEHRING, E.; BOSCHETTI, I. Política Social: fundamentos e história. São Paulo: Cortez, 2006. (Biblioteca Básica do Serviço Social; v. 2).

BIANCHETTI, L. Aspectos históricos da apreensão e da educação dos considerados deficientes. In: BIANCHETTI, L.; FREIRE, I. M. (orgs). Um olhar sobre a diferença: interação, trabalho e cidadania. Campinas, SP: Papirus, 1998. p. 21-51.

BOSCHETTI, Ivanete. A política de seguridade social no Brasil. In: Serviço Social: direitos sociais e competências profissionais. Brasília: CFESS/ABEPSS, 2009.

Assistência Social no Brasil: um direito entre originalidade e conservadorismo. Brasília, 2002.

Seguridade social e trabalho: paradoxos na construção das políticas de previdência e assistência social no Brasil. Brasília: Letras Livres/Editora UnB, 2006.

Seguridade Social na América Latina. In: BOSCHETTI; BEHRING; SANTOS; MIOTO (Orgs.). Política social no capitalismo: tendências contemporâneas. São Paulo: Cortez, 2008.

BOSCHETTI, Ivanete; SALVADOR, Evilásio. Orçamento da seguridade social e política econômica: perversa alquimia. Revista Serviço Social \& Sociedade, São Paulo, n. 87, pp. 25-57, 2006. 
BOSCHETTI, Ivanete Salete; TEIXEIRA, Sandra Oliveira; DIAS, Adriane Tomazelli. A execução orçamentária da política de assistência social e dos programas para crianças e adolescentes. Serviço Social \& Sociedade, v. 85, p. 71-97, 2006.

BRASIL. Ação Civil Pública n. 2007. 30.00.000204.-0, de 11 de abril de 2007. Proposta pelo Ministério Público Federal e Defensoria Pública Federal contra o Instituto Nacional de Seguro Social (INSS), que trata dos critérios de elegibilidade do Benefício de Prestação Continuada. Brasil, 2007c.

Constituição da República Federativa do Brasil. Brasília: Gráfica do Senado Federal, 1988. Brasil, 1988.

Decreto n. 1.330, de 08 de dezembro de 1994. Dispõe sobre a concessão do benefício de prestação continuada, previsto no art. 20 da Lei n. 8.742, de 7 de dezembro de 1993, e dá outras providências. Brasil, 1994.

Decreto n. 1.744, de 08 de dezembro de 1995. Regulamenta o benefício de prestação continuada devido à pessoa portadora de deficiência e ao idoso, de que trata a Lei n. 8.742, de 07 de dezembro de 1993, e dá outras providências. Brasil, 1995.

Decreto n. 3.298, de 20 de dezembro de 1999. Regulamenta a Lei n. 7.853, de 24 de outubro de 1989, dispõe sobre a Política Nacional para a Integração da Pessoa Portadora de Deficiência, consolida as normas de proteção, e dá outras providências. Brasil, 1999.

Decreto n. 3.956, de 8 de outubro de 2001. Promulga a Convenção Interamericana para a Eliminação de Todas as Formas de Discriminação contra as Pessoas Portadoras de Deficiência. Brasil, 2001.

Decreto n. 6.214, de 26 de setembro de 2007. Regulamenta o Benefício de Prestação Continuada da Assistência Social devido à pessoa com deficiência e ao idoso de que trata a Lei n. 8.742, de 07 de dezembro de 1993, e a Lei n. 10.741, de $1^{\circ}$ de outubro de 2003, acresce parágrafo ao art. 162 do Decreto n. 3.048, de 06 de maio de 1999, e dá outras providências. Brasil, 2007a.

Decreto n. 6.564, de 12 de setembro de 2008. Altera o Regulamento do Benefício de Prestação Continuada, aprovado pelo Decreto no 6.214, de 26 de setembro de 2007, e dá outras providências. Brasil, 2008.

Decreto n. 6.949, de 25 de agosto de 2009. Promulga a Convenção Internacional sobre os Direitos das Pessoas com Deficiência e seu Protocolo Facultativo, assinados em Nova York, em 30 de março de 2007. Brasil, 2009b.

Lei n. 3.807, de 26 de agosto de 1960. Dispõe sobre a Lei Orgânica da Previdência Social. Brasil, 1960.

Lei n. 8.213, de 27 de julho de 1991. Dispõe sobre os Planos de Benefícios da Previdência Social e dá outras providências. Brasil, 1991.

Lei n. 8.742, de 08 de dezembro de 1993. Dispõe sobre a Lei Orgânica da Assistência Social. Diário Oficial da União 1993. Brasil, 1993.

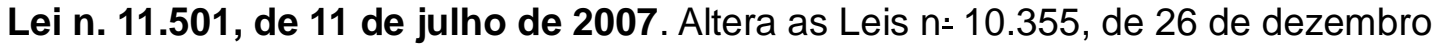
de 2001, 10.855, de 1ํ de abril de 2004, 8.112, de 11 de dezembro de 1990, 11.457, de 16 
de março de 2007, 10.910, de 15 de julho de 2004, 10.826, de 22 de dezembro de 2003, 11.171, de 2 de setembro de 2005, e 11.233, de 22 de dezembro de 2005; revoga dispositivos das Leis n-11.302, de 10 de maio de 2006, 10.997, de 15 de dezembro de 2004, 8.212, de 24 de julho de 1991, 9.317, de 5 de dezembro de 1996, 10.593, de 6 de dezembro de 2002, 11.098, de 13 de janeiro de 2005, 11.080, de 30 de dezembro de 2004; e dá outras providências. Brasília, 2007e.

Ministério do Desenvolvimento Social e Combate à fome (MDS). Avaliação de pessoas com deficiência para acesso ao Benefício de Prestação Continuada da Assistência Social: um novo instrumento baseado na Classificação Internacional de Funcionalidade, Incapacidade e Saúde. Brasília, DF: MDS, 2007d.

Ministério do Desenvolvimento Social e Combate à fome (MDS). Benefício de Prestação Continuada. Disponível em <www.mds.gov.br>. Acesso em 7 ago. 2010. Brasil, 2007b.

Portaria Conjunta MDS/INSS n. 1, de 29 de maio de 2009. Institui Instrumentos para a avaliação da deficiência e do grau de incapacidade de pessoas com deficiência requerentes ao Benefício de Prestação Continuada da Assistência Social - BPC, conforme estabelece o art. 16, $\S 3^{\circ}$, do Decreto n. 6.214, de 26 de setembro de 2007, alterado pelo Decreto n. 6.564, de 12 de setembro de 2008. Brasil, 2009b.

CARDOSO, Vanessa M. Dificultadores e facilitadores no processo de inclusão da pessoa com deficiência no mercado formal de trabalho. 2006, 62 f. Monografia (graduação). Pontifícia Universidade Católica de Minas Gerais. Curso de Psicologia, Unidade Coração Eucarístico.

CARTAXO, Ana Maria B. Estratégias de Sobrevivência: a Previdência e o Serviço Social. São Paulo: Cortez, 1995.

Seguridade Social e Projeto Ético-Político Profissional: desafios aos/às
Assistentes Sociais na Previdência Social. Disponível em: <http://www.cfess.org.br/arquivos/slide_anacartaxo.pdf>. Acesso em: 7 ago. 2010. 2010.

CARTAXO, Ana Maria B.; CABRAL, Maria do Socorro R. O processo de descontrução e reconstrução do projeto profissional do Serviço Social na Previdência - um registro de resistência e luta dos Assistentes Sociais. In: BRAGA; CABRAL (Org.). Serviço social na Previdência: trajetória, projetos profissionais e saberes. 3. ed. São Paulo: Cortez, 2008.

CFESS. Conselho Federal de Serviço Social. Ação de Inconstitucionalidade promovida pelo Conselho Federal de Serviço Social junto ao Ministério Público da União. CFESS, 1996.

Código de Ética do Assistente Social. Aprovado pela resolução CFESS n. 273/93. Brasília: CFESS, 1993.

. Histórico da Luta em Defesa do Concurso Público e de Condições de Trabalho para os/as Assistentes Sociais do INSS. Disponível em: $<$ www.cfess.org.br/arquivos/historico_defesaAS_inss.pdf>. Acesso em: 28 jul. 2010. CFESS, 2010a.

Parecer Jurídico CFESS 12, de 1‥ abril de 2010. Disponível em: <http://www.cfess.org.br/arquivos/parecerjuridico12-2010_inss.pdf>. Acesso em: 28 jul. 2010. 
Resolução n. 493, de 21 de agosto de 2006. Dispõe sobre as condições éticas e técnicas do exercício profissional do assistente social. CFESS, 2006.

CHAGAS, Ana Maria de R. Avanços e Impedimentos para a Construção de uma Política Social para as Pessoas com Deficiência. Dissertação de Mestrado. Brasília: UnB/SER, 2006.

CLEMENTE, Carlos Aparício. Trabalhando com a diferença: responsabilidade social \& inclusão de portadores de deficiência. Brasília: Edição especial. Ministério do Trabalho e Emprego. 2004.

COHEN, L.; MANION, I. Métodos de investigación educativa. Madrid: La Muralla, 1990.

COMBESSIE, Jean-Claude. O método em Sociologia: o que é, como se faz? São Paulo: Edições Loyola, 2004.

CONVENÇÃO DA GUATEMALA. Convenção interamericana para a eliminação de todas as formas de discriminação contra as pessoas portadoras de deficiência. 2006. Disponível em: <http://portal.mec.gov.br/seesp/arquivos/pdf/guatemala.pdf>. Acesso em: 17 jun. 2010.

COSTA, S. J. D. O. (2009). O benefício assistencial e suas questões controvertidas. Âmbito Jurídico, (66), 1-3. 2009.

CRESWELL, John. Projeto de Pesquisa: Métodos qualitativo, quantitativo e misto. Porto Alegre: Artmed - Bookman, 2007.

DINIZ, Debora. O que é deficiência. São Paulo: Brasiliense, 2007. (Coleção Primeiros Passos; 324).

DINIZ, Debora; SQUINCA, Flávia; MEDEIROS, Marcelo. Qual Deficiência? Perícia Médica e Assistência Social no Brasil. Cad. de Saúde Pública. Vol. 23, n. 11. pp. 2589-2596. FIOCRUZ: Rio de Janeiro, 2007.

DUARTE, Janaína L. N. O Serviço Social nas Organizaçoes Não-Governamentais: tendências e particularidades. Dissertação de Mestrado. Natal: UFRN, 2007.

FALEIROS, Vicente de P. Tecnocracia e Assistencialismo no capitalismo autoritário. 0 Serviço Social na Previdêncai Social dos anos 70. In: BRAGA; CABRAL (Org.). Serviço social na Previdência: trajetória, projetos profissionais e saberes. 3. ed. São Paulo: Cortez, 2008.

FARIAS, Norma; BUCHALLA, Cássia M. Classificação Internacional de Funcionalidade, Incapacidade e Saúde da Organização Mundial da Saúde: conceitos, usos e perspectivas. Revista Brasileira de Epidemiologia, v. 8, n. 2, pp. 187-193, 2005.

FÁVERO, Eunice T. O Estudo social - fundamentos e particularidades de sua construção na Área Judiciária. In: O Estudo social em Perícias, Laudos e Pareceres Técnicos: Contribuição ao debate no Judiciário, Penitenciário e na Previdência Social. Conselho Federal de Serviço Social (Org.). 8. ed. São Paulo: Cortez, 2008.

FOUCAULT, Michael. O Nascimento da Clínica. Rio de Janeiro: Forense Universitária, 1994. 
GODOY, A. S. Introdução à pesquisa qualitativa e suas possibilidades. In: Revista de Administração de Empresas, v. 35, n. 2, 1995.

GOFFMAN, Erving. Estigma: notas sobre a manipulação da identidade deteriorada. Rio de Janeiro: Livros Técnicos e Científicos (LCT), 1988.

GOMES, Ana Lígia. O Benefício de Prestação Continuada: Uma Trajetória de Retrocessos e Limites - Construindo Possibilidades de Avanços? In: SPOSATI, A. (org.). Proteção Social de Cidadania: inclusão de idosos e pessoas com deficiência no Brasil, França e Portugal. 2. ed. São Paulo: Cortez, 2008.

O Benefício de Prestação Continuada: uma trajetória de retrocessos e limites. In: Revista Serviço Social \& Sociedade, n. 68. São Paulo: Cortez, 2001.

GUEDES, Carla Ribeiro; NOGUEIRA, Maria Inês; CAMARGO JR., Kenneth R. de. A Subjetividade como Anomalia: contribuições epistemológicas para a crítica do modelo biomédico. Ciência e Saúde Coletiva, v. 11, n. 4, Rio de Janeiro, out./dez. 2006.

GUERRA, Yolanda. A instrumentalidade do Serviço Social. São Paulo: Cortez, 1995.

GUIMARÃES, Tania M. R.; MIRANDA, Wagner L.; TAVARES, Márcia M. F. O cotidiano das famílias de crianças e adolescentes portadores de anemia falciforme. Revista Brasileira de Hematologia e Hemoterapia, v. 31, n. 1, pp. 9-14, jan./fev. 2009.

HUBERMAN, L. História da riqueza do homem. Rio de Janeiro: Zahar, 1995.

IAMAMOTO, Marilda Villela. Serviço social em tempo de capital fetiche: capital financeiro, trabalho e questão social. São Paulo: Cortez, 2008.

IAMAMOTO, Marilda V.; CARVALHO, Raul de. Relações Sociais e Serviço Social no Brasil: esboço de uma interpretação histórico-metodológica. 18. ed. São Paulo: Cortez, 2005.

IBGE. Censo Demográfico 2000. Brasil: IBGE, 2000.

INPS. Instituto Nacional da Previdência Social. Resolução INPS n. 401.4 de 7/2/1972. Plano Básico de Ação do Serviço Social. INPS, 1972.

INSS. Instituto Nacional do Seguro Social. Coordenação Geral de Serviços Previdenciários QG Nacional da LOAS. Comunicado n. 01/95. Brasília, 1995.

Coordenação Geral de Serviços Previdenciários - QG Nacional da LOAS. Comunicado no 01/96. Brasília, 1996.

Matriz Teórico-Metodológica do Serviço Social na Previdência Social. Brasília, $\overline{M P A S / I N S S / D i v i s a ̃ o ~ d e ~ S e r v i c ̧ o ~ S o c i a l . ~ I N S S, ~} 1994$.

Ordem Interna - INSS/DIRBEN/no 081. Brasília, 2003.

MACEDO, Myrtes de Aguiar. Reconceituação do Serviço Social: formulações diagnósticas. 3. ed. São Paulo: Cortez, 1986.

MARTINELLI, M. L. Serviço Social: identidade e alienação. São Paulo: Cortez, 2000.

MEDEIROS, Marcelo; DINIZ, Debora. Envelhecimento e deficiência. Série Anis 36. 
Brasília: LetrasLivres, junho, 2004.

MEDEIROS, Marcelo; DINIZ, Debora; SQUINCA, Flávia. Estudo do Programa Brasileiro de Transferência de Rendas para a População com Deficiência e suas Famílias: uma análise do Benefício de Prestação Continuada. Texto para discussão n. 1184, IPEA: Brasília, 2006.

MEDEIROS, M.; NETTO, Melchior Sawaya; BARROS, Fábio H. Granja e. A distribuição das transferências, público-alvo e cobertura do Benefício de Prestação Continuada. Revista Textos e Contextos, v. 8, n. 2. Porto Alegre: PUCRS, 2009.

MIOTO, Regina Célia T. Perícia Social - proposta de um percurso operativo. In: Revista Serviço Social e Sociedade, n. 67. Especial "Temas Sócio-jurídicos". São Paulo: Cortez, 2001.

MOREIRA, Marinete C. O Serviço Social do INSS a partir da década de 1990: análise da implantação da Matriz Teórico-Metodológica. In: BEHRING; ALMEIDA (Org.). Trabalho e seguridade social: percursos e dilemas. São Paulo: Cortez; Rio de Janeiro: FSS/UERJ, 2008.

Benefício Assistencial: tensões e avanços na concretização deste direito constitucional. Disponível em: <http://www.cfess.org.br/arquivos/slide_marinete.pdf>. Acesso em: 7 ago. 2010.

MOTA, Ana Elizabete. A centralidade da Assistência Social na Seguridade Social brasileira nos anos 2000. In: MOTA (Org.). O Mito da assistência social: ensaios sobre Estado, política e sociedade. 4. ed. São Paulo: Cortez, 2010.

3, p. 9-14, 2003.

As dimensões da prática profissional. Revista Presença Ética. Recife, ano 3, n.

Questão Social e Serviço Social: um debate necessário. In: MOTA (Org.). O Mito da assistência social: ensaios sobre Estado, política e sociedade. 4. ed. São Paulo: Cortez, 2010a.

MTPS. Ministério do Trabalho e da Previdência Social. Resolução MTPS n. 1.081 de 26/10/1965. Aprovação do Ato Normativo n. 27 / DNPS - Normas Gerais para o Serviço Social. MTPS, 1965.

NERI, Marcelo Côrtes. Retratos da Deficiência no Brasil. Rio de Janeiro: FGV, 2003.

NERI, Marcelo Côrtes; SOARES, Wagner Lopes. Idade, incapacidade e o número de pessoas com deficiência. In: Revista B. de Estudos Populacionais, v. 21, n. 2, p. 303-321, jul.- dez., 2003.

NETTO, José Paulo. Ditadura e Serviço Social: uma análise do Serviço Social no Brasil pós-64. 8. ed. São Paulo: Cortez, 2007.

Introdução ao método na teoria social. In: Serviço Social: direitos sociais e competências profissionais. Brasília: CFESS/ABEPSS, 2009.

NEVES, Márcia E. R.; SILVA, Maria de J. da. Previdência Social: construção da prática do Serviço Social. In: BRAGA; CABRAL (Org.). Serviço social na Previdência: trajetória, projetos profissionais e saberes. 3. ed. São Paulo: Cortez, 2008. 
OIT. Organização Internacional do Trabalho. Convenção n. 159. Dispõe sobre reabilitação profissional e emprego de pessoas deficientes. 2001. Disponível em: $<$ http://www.unisc.br/universidade/estrutura_administrativa/nucleos/naac/docs/convencoes/c onvencao_oit.pdf>. Acesso em: 17 jun. 2010.

OLIVER, Michael. The Politics of Disablement. London: MacMillan, 1990.

OLIVER, Michael e BARNES, Colin. Disabled People and Social Policy: from exclusion to inclusion. London: Longman, 1998.

ONU. Organização das Nações Unidas. Resolução ONU 48/96, de 20 de dezembro de 1993.

PEREIRA, Ana A. Visão sistêmica do Serviço Social em sua prática no INPS. Brasília, 1978.

PEREIRA, Potyara Amazoneida P. A assistência social na perspectiva dos direitos: crítica aos padrões dominantes de proteção aos pobres no Brasil. Brasília: Thesaurus, 2006.

A política social no contexto da seguridade social e do welfare state: a particularidade da assistência social. In: Revista Serviço Social \& Sociedade, n. 56, São Paulo, Cortez, 1998.

SASSAKI, Romeu. Inclusão: construindo uma sociedade para todos. Rio de Janeiro: WMA, 1997.

SCHWARZ, Andrea; HABER, Jaques. População com deficiência no Brasil - fatos e percepções (Coleção FEBRABAN de inclusão social). FEBRABAN, 2006.

SILVA, Ademir A. O Serviço Social na Previdência Social: entre a necessidade social e o benefício. In: BRAGA; CABRAL (Org.). Serviço social na Previdência: trajetória, projetos profissionais e saberes. 3. ed. São Paulo: Cortez, 2008.

SILVA, Maria Lucia L. da. Serviço Social no INSS - luta para garantir direitos e cidadania. Revista Inscrita, Ano II, n. 5. Brasília: CFESS, 1999.

SILVA, O. M. A Época Ignorada: A Pessoa Deficiente na História do Mundo de Ontem e de Hoje. São Paulo; Caderno Cedes, 1986.

SILVA, Roberto B. de Paiva e; RAMALHO, Antonio S.; CASSORLA, Roosevelt M. S. A anemia falciforme como problema de Saúde Pública no Brasil. Revista de Saúde Pública, v. 27, n. 1, p. 54-58, fev. 1993.

SILVEIRA BUENO, J. G. Educação especial brasileira: integração/segregação do aluno diferente. São Paulo: EDUC, 1993.

SPOSATI, Adaílza. Benefício de Prestação Continuada como Mínimo Social. In: SPOSATI, A. (org.). Proteção Social de Cidadania: inclusão de idosos e pessoas com deficiência no Brasil, França e Portugal. 2. ed. São Paulo: Cortez, 2008.

SQUINCA, Flávia. Deficiência e Aids: o Judiciário e o Benefício de Prestação Continuada. Dissertação de Mestrado. Brasília: UnB/FS, 2007. 
Tópicos em Bioética. Brasília: LetrasLivres, 2006, p. 82-94.

STRAUSS, A.; CORBIN, J. Pesquisa Qualitativa: Técnicas e Procedimentos para o Desenvolvimento de Teoria Fundamentada. 2. Ed., Porto Alegre, Artmed, 2008.

THOMAS, Carol; CORKER, Mairian. A Journey around the Social Model. In: CORKER, Mairian; SHAKESPEARE, Tom. Embodying Disability Theory. Londres: Continuum, 2004.

WENDELL, Susan. Unhealthy Disabled: treating chronic illnesses as disabilities. Hypathia, v. 16, n. 2, pp. 17-33, Fall 2001.

WHO. World Health Organization. CIF: Classificação Internacional de Funcionalidade, Incapacidade e Saúde. São Paulo: Universidade de São Paulo, 2001.

WHO. World Health Organization. International Classification of Impairments, Disabilities and Handicaps (ICIDH). Geneva, 1980.

WILLIAMS, Gareth. Theorizing Disability. In: ALBRECHT, Gary L.; SEELMAN, Katherine D.; BURY, Michael. Handbook of Disability Studies. London: Sage, 2001. Pp. 123-143.

YAZBEK, M. C. Classes Subalternas e Assistência Social. São Paulo: Cortez, 1993. 


\section{ANEXO \\ ROTEIRO PARA ENTREVISTA SEMI-ESTRUTURADA}

1. Há quanto tempo é assistente social do INSS?

2. Quais são as competências e atribuições profissionais do assistente social no INSS?

3. Qual a sua análise sobre as atribuições e competências do assistente social no INSS?

4. A Sra avalia que todas as suas atividades executadas são próprias do Serviço Social? A $\mathrm{Sr}^{\mathrm{a}}$. realiza a atividade de habilitação do BPC? Considera desvio de função?

5. Qual a sua análise sobre os aspectos materiais do seu trabalho?

6. Qual a sua análise sobre os aspectos técnicos do seu trabalho?

7. Qual a sua análise sobre os aspectos éticos do seu trabalho?

8. Existe autonomia no exercício da sua profissão?

9. Como é a relação profissional entre a $\mathrm{Sr}^{\mathrm{a}}$. e o gestor ou chefe da agência?

10. Como é a sua relação profissional com a chefe do Serviço Social?

11. Como a Sra . avalia os critérios estabelecidos pelo governo para dizer quem tem direito ao BPC?

12. $\mathrm{A} \mathrm{Sr}^{\mathrm{a}}$. acha que a perícia médica é suficiente para avaliar a incapacidade para a vida independente e para o trabalho de uma pessoa com deficiência?

13. O que a Sr${ }^{a}$. entende por deficiência?

14. Qual a média numérica de avaliações sociais que executa por dia?

15. Qual é o objetivo da avaliação social para acesso ao BPC?

16. Como a Sra ${ }^{\text {. }}$ avalia o instrumento de avaliação social para acesso ao BPC?

17. A $\mathrm{Sr}^{\mathrm{a}}$. recebeu algum tipo de treinamento, curso ou especialização para realizar as avaliações sociais para acesso ao BPC?

18. Caso tenha feito o treinamento, o que achou? Por quê?

19. Caso não tenha feito algum tipo de treinamento, a $\mathrm{Sr}^{\mathrm{a}}$. acha que é necessário que haja treinamento para executar a avaliação social?

20. Como se avalia os fatores ambientais no instrumento de avaliação social?

21. Como se avalia o domínio atividade e participação no instrumento de avaliação social?

22. A Sra . acredita que todas as assistentes sociais que realizam a avaliação social 
interpretam os fatores ambientais e atividade e participação da mesma forma?

23. A Sr ${ }^{a}$. realiza visita domiciliar para conhecer as condições de moradia da pessoa com deficiência que solicita o BPC? O que acha dessa prática?

24. Quais os desafios encontrados no preenchimento do formulário para acesso ao BPC?

25. Quais os desafios encontrados na análise da avaliação social?

26. Como é a dinâmica da avaliação social na relação assistente social e pessoa com deficiência?

27. A avaliação social é um instrumento que contribui para a redução de desigualdades? Por quê? 